\title{
The Impact of SARS-CoV-2 Lineages (Variants) on the COVID-19 Epidemic in South Africa
}

\author{
Thabo Mabuka ${ }^{1}$, Natalie Naidoo ${ }^{2}$, Nesisa Ncube ${ }^{3}$, Thabo Yiga ${ }^{4}$, Michael Ross ${ }^{5}$, Kuzivakwashe Kurehwa ${ }^{6}$, \\ Mothabisi Nare $^{7}$, Andrea Silaji ${ }^{8}$, Tinashe Ndemera9, Tlaleng Lemeke ${ }^{10}$, Taiwo Ridwan Ademola ${ }^{11}$, Willie \\ Macharia $^{12}$, Mthokozisi Sithole ${ }^{13}$ \\ 1,2,3,4,5,6,7,8,9,10,11,12,13-African COVID-19 Modelling Research Group (ACMRG) and African Disease Demographics Research \\ Group (ADDRG), The Afrikan Research Initiative (ARI);
}

*Correspondence: research@ afrikanresearchinitiative.com; Tel.: +27-71-610-1736

Received: date; Accepted: date; Published Date; 21/10/2021

\begin{abstract}
Emerging SARS-CoV-2 variants have been attributed to the occurrence of secondary and tertiary COVID-19 epidemic waves and also threatening vaccine efforts due to their immune invasiveness. Since the importation of SARS-CoV-2 in South Africa, with the first reported COVID-19 case on the 5th of March 2020, South Africa has observed 3 consecutive COVID-19 epidemic waves. The evolution of SARS-CoV-2 has played a significant role in the resurgence of COVID-19 epidemic waves in South Africa and across the globe. South Africa has a unique observation of the evolution of SARS-CoV-2, with distinct SARS-CoV-2 lineages dominating certain epidemic periods. This unique observation allows for an investigation of the detected SARS-CoV-2 lineages' impact on COVID-19 transmissibility and severity through analysis of epidemiological data. In this study, inferential statistical analysis was conducted on South African COVID-19 epidemiological data to investigate the impact of SARS-CoV-2 lineages in the South African COVID-19 epidemiology. The general methodology in this study involved the collation of South African COVID-19 epidemiological data, the regression and normalisation of the epidemiological data, and inferential statistical analysis. This study shows that the evolution of SARS-CoV-2 resulted in an increase in COVID-19 transmissibility and severity in South Africa. The Delta SARS-CoV-2 VOC resulted in increased COVID-19 transmissibility in the South African population by 53.9 to $54.8 \%$ more than the Beta SARS-CoV-2 VOC and the predominantly B.1.1.54, B.1.1.56 C.1 SA SARSCoV-2 lineage cluster. The Beta SARS-CoV-2 VOC resulted in more severe COVID-19 in South Africa than the Delta SARS-CoV-2 VOC. While, both the Beta and Delta SARS-CoV-2 VOC resulted in more severe COVID19 than the initial SARS-CoV-2 lineages detected in South Africa's first epidemic wave period. The Delta, Beta SARS-CoV-2 VOCs and the predominantly B.1.1.54, B.1.1.56 C.1 SA SARS-CoV-2 lineage cluster were observed to cause similar COVID-19 hospital case fatality and discharge rates in South African hospitals.
\end{abstract}

Keywords: COVID-19, SARS-CoV-2, Variants, Lineages, Mutations, South Africa, Epidemiology, Statistics

\section{Introduction}

On the $11^{\text {th }}$ of March 2020, the World Health Organisation (WHO) declared the Coronavirus Disease 2019 (COVID-19) a global pandemic [1]. The COVID-19 pandemic has resulted in more than 4809907 deaths in the reporting period up to the $1^{\text {st }}$ of October 2021 [2]. Public health measures such as nationwide lockdowns aimed at reducing the transmission of COVID-19 have come at a great cost to the world economy [3]. While, there is global consensus on the health risk posed by COVID-19, ground-breaking vaccine developments, and a great drive towards the vaccination of the world population against COVID-19. There are however challenges that persist in controlling the Global COVID-19 transmission and severity. One challenge is the large disparity in access to vaccines between the developing and developed worlds [4]. Another challenge is the emergent of SARS-CoV-2 lineages and sub-lineages (variants) with increased transmissibility [5]. Lineages and sub-lineages are a series of entities (in this case genetic) forming a single line of direct ancestry and descent [6]. Emerging SARS-CoV-2 variants have been attributed to the occurrence of secondary and tertiary COVID-19 epidemic waves and also threatening vaccine efforts due to their immune invasiveness [7].

SARS-CoV-2 is the virus that causes COVID-19 upon infecting a human host. SARS-CoV-2's early

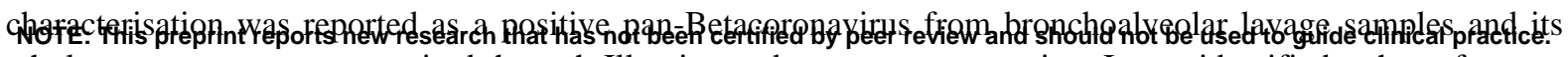
whole genome sequence acquired through Illumina and nanopore sequencing. It was identified to have features 
typical of Coronaviruses belonging to the Betacoronavirus $2 \mathrm{~B}$ lineage. Betacoronaviruses belong to the subfamily Othrocoronavirinae of the Coronaviridae family, order Nidovirales. A close relationship was found between SARS-CoV-2 with the BatCoV Rat G13 virus (from the bat (Rhinolophus affinis)) at $96 \%$ identity [8]. The genetic sequence of SARS-CoV-2 was shared on the $12^{\text {th }}$ of January $2020[9,10]$. Coronaviruses are positive-stranded Ribonucleic Acid (RNA) viruses. The presence of spike glycoproteins in their envelope gives them a crown-like appearance under an electron microscope [11]. The genome of SARS-CoV-2 is a single positive-stranded RNA approximately 29903 bases (nucleotides) pairs in length $[9,10,12,13]$. There are at least 50 different open reading frames (ORFs) in the SARS-CoV-2 genome which include start codon (AUG) and stop codons (UAG, UAA, UGA). Origin of transcription sequences allow for SARS-CoV-2 to encode for 50 protiens with structural, nonstructural and accessory functions $[10,14,15]$. Two-thirds of the SARS-CoV-2 genome encodes for the two main transcription units, ORF1a and ORF1b which are attributed in the encoding of polyproteins, PP1a and PP1ab respectively. PP1ab contains ORFs for 16 nonstructural proteins (Nsp1-Nsp16). Non-structural proteins have functions in replication, proofreading, translation, suppressing host proteins, blocking immune responses, and stabilisation $[10,15]$. One-third of the SARS-CoV-2 genome encodes the structure and accessory proteins. Accessory genes are positioned along with the structural genes. There are at least nine ORFs for accessory proteins in the SARS-CoV-2 genome. Accessory proteins do not play a significant role in viral replication but play a role in the interaction between the viral genome and the host particularly blocking the production of cytokines $[10,14,15]$. With regards to structure, there are four main structural proteins in SARS-CoV-2. These are the Spike (S), Membrane (M), Envelope (E), and the Nucleocapsid (N) proteins. The Nucleocapsid proteins coat the SARSCOV-2 RNA for genetic protection [10,13-15].

During infection, the Spike glycoprotein undergoes cleavage (unique furin-like cleavage site (FCS)) into amino (N) terminal S1 and carboxyl (C)-terminal S2 subunits $[10,16]$. The SI subunit facilitates the incorporation of SAR-CoV-2 into the host cell while the S2 subunit is responsible for membrane fusion. The S1 subunit has a receptor binding (RBD) and N-terminal (NTD) domain. SARS-CoV-2 binds to the human angiotensin-converting enzyme 2 (ACE2) receptors which are abundant in the respiratory epithelium but are also expressed by other cells such as the upper oesophagus, enterocytes (ileum), myocardial cells, proximal tubular cells (kidney), and urothelial cells (bladder). The binding is achieved through the SARS-CoV-2 Spike Protein (S1). Once the attachment has been achieved priming of the SARS-CoV-2 Spike Protein (S2) by the host transmembrane serine protease 2 (TMPRSS2) allows for viral cell entry and replication endocytosis [10,13].

One of the first reported SARS-CoV-2 genomes was the Wuhan-Hu-1 (MN908947.3) (sampled on the $26^{\text {th }}$ of December 2019) [9] and the Wuhan/WH04/2020 [17] strains. In July 2020, a dynamic nomenclature for SARSCoV-2 lineage assignment was designed by Rambaut et al, $2020[12,18]$ and an algorithm to outline links in viral genomes developed known as the Phylogenetic Assignment of Named Global Outbreak LINeages (PANGOLIN) $[18,19]$. Based on this classification, 2 major lineages can be identified in the main phylogeny of SARS-CoV-2, lineages A and B. Lineage A can be defined based on the Wuhan/WH04/2020 genome sharing 2 nucleotides (positions 8782 in ORF1ab and 28144 in ORF8) while lineage B has different nucleotides present at those sites such as the Wuhan-Hu-1 genome $[12,18]$. By the $20^{\text {th }}$ of December 2020, there were 261487 whole or partial genome sequences publicly available, shared through the Global Initiative on Sharing Avian Influenza Data (GISAID) [12]. From this genomic data, sub-lineages of lineages A and B were identified. Two main lineages were also identified, lineage $\mathrm{C}$ and $\mathrm{D}$, and these were reassigned to the classification of lineage $\mathrm{B}$. More than 266 lineages/sub-lineages were identified globally $[12,18]$. In the year 2020, lineage B and sub-lineage B.1 were the most reported in genetic samples worldwide [12].

Whole-genome sequencing of 104 strains of SAR-CoV-2 from patients with COVID-19 symptom onsets in the period of December 2019 to Mid-February 2020 showed $99.9 \%$ homology, without significant mutations [8]. However, the rapid spread of SARS-CoV-2 has allowed the virus opportune replications to evolve into different lineages and sub-lineages. RNA viruses are prone to genetic evolution with resultant genomes that have different characteristics than the ancestral strain [13]. Coronaviruses including SARS-CoV-2 can proofread during replication however this has not limited the mutation of the SARS-CoV-2 genome in forming new lineages and sub-lineages [20]. To prioritise global monitoring and research and to inform the ongoing response to the COVID19 pandemic, SARS-CoV-2 variants have been characterised as either 'Variants of Concern' (VOCs)' or 'Variants of Interest' (VOIs)'. The main characteristics of VOCs are that they have evidence of an increase in transmissibility, more severe disease that leads to increased hospitalisation or deaths, therefore reducing the effectiveness of public health and social measures [21]. Additionally, VOCs significantly reduce the neutralisation of antibodies generated during previous infection or vaccination which ultimately reduces the effectiveness of 
medRxiv preprint doi: https://doi.org/10.1101/2021.10.22.21265316; this version posted October 25, 2021. The copyright holder for this preprint (which was not certified by peer review) is the author/funder, who has granted medRxiv a license to display the preprint in perpetuity.

It is made available under a CC-BY 4.0 International license.

treatments or vaccines, or diagnostic detection [22]. Variants of Interest (VOIs) are variants whose changes have predicted genetic markers that are known to affect virus characteristics such as transmissibility, disease severity, immune escape, diagnostic or therapeutic escape [21]. They are also identified to have a predictable increase in transmissibility or disease severity thus having an apparent epidemiological impact to suggest an emerging risk to global public health $[21,22]$. The SARS-CoV-2 variants that have been characterised as VOCs by WHO are the Alpha (B.1.1.7), Beta (B.1.351, B1.351.2, B.1.351.3), Gamma (P.1, P.1.1, P.1.2, P.1.4, P1.6, P.1.7), and Delta (B.1.617.2, AY.1, AY.2, AY.3, AY.3.1) SARS-CoV-2 lineages (WHO, 2021; CDC, 2021). While, the variants that have been characterised as VOIs are the Eta (B.1.525), Iota (B.1.526), Kappa (B.1.617.1), and Lambda (C.37) SARS-CoV-2 lineages [21].

The Alpha SARS-CoV-2 VOC (B.1.1.7 lineage) (formerly GR/501Y.V1) was reported in December 2020 based on United Kingdom whole-genome sequence samples from patients with positive laboratory tests of SARS-CoV$2[23,24]$. This lineage was also detected in commercial assays due to the absence of the S gene in PCR samples. The B.1.1.7 lineage had 17 mutations in its genome. Eight of these mutations were in the Spike protein at $\Delta 69-70$ deletion, $\Delta 144$ deletion, N501Y, A570D, P681H, T716I, S982A, and D1118H [13,23,25]. The mutation at N501Y showed increased affinity by the Spike protein in SARS-CoV-2 to the ACE 2 receptors. The B.1.1.7 lineage was reported to be $43 \%$ to $82 \%$ more transmissible and became the dominant SAR-CoV-2 lineage in the UK [26]. The Gamma SARS-CoV-2 variant (P.1, P.1.1, P.1.2, P.1.4, P1.6, P.1.7 lineages) (formerly GR/501Y.V3.) was identified in December 2020 in Brazil [27] and the United States(US) in January 2021 [13]. The P.1 lineage had 10 mutations in the Spike protein at 18F, T20N, P26S, D138Y, R190S, H655Y, T1027I V1176, K417T, E484K, and N501Y. Three of those mutations (L18F, K417N, E484K) were located in the RBD [27]. The Gamma SARSCoV-2 variant showed reduced neutralization by monoclonal antibody therapies, post-vaccination, and convalescent sera [28]. The Delta (B.1.617.2, AY.1, AY.2, AY.3, AY.3.1 lineage) and the Kappa (B.1.617.1 lineage) SARS-CoV-2 variants were first identified in December 2020 in India [29]. The Delta SARS-CoV-2 variant was initially considered a VOI by the WHO but was subsequently classed as a VOC during the deadly second COVID-19 epidemic wave in India in April 2021 [30,31]. The Delta SARS-CoV-2 VOC had 10 mutations in the Spike protein at T19R, (G142D*), 156del, 157del, R158G, L452R, T478K, D614G, P681R, and D950N [29]. While the Kappa SARS-CoV-2 VOI had Spike protein mutations of interest at T95I, G142D, E154K, L452R, E484Q, D614G, P681R, and Q1071H [32]. The Delta SARS-CoV-2 variant was also detected in March 2021 in the US and became the dominant SARS-CoV-2 lineage in the US. Prior, the Eta (B.1.525 lineage), and Iota (B.1.526 lineage) SARS-CoV-2 VOIs were detected in the US in November 2020 [13]. They had Spike protein mutations of interest at B.1.525: A67V, $\Delta 69 / 70, \Delta 144$, E484K, D614G, Q677H, F888L and B.1.526: L5F*, T95I, D253G, S477N*, E484K*, D614G, A701V* respectively [33,34]. While in South America, the Lambda (C.37 lineage) SARS-CoV-2 variant was detected in Peru and classed as a VOI due to its increased presence in SARSCoV-2 genetic samples from the region [35-37].

Of interest in this study is the impact of the SARS-CoV lineages and sub-lineages in the COVID-19 epidemic waves in South Africa. Since the importation of SARS-CoV-2 in South Africa, with the first reported COVID-19 case on the $5^{\text {th }}$ of March 2020, South Africa has observed 3 consecutive COVID-19 epidemic waves [2,38]. The first COVID-19 epidemic wave in South Africa was observed between the reporting periods of 5 March to 30 September 2020 with a peak of 173587 Active COVID-19 cases and a peak date of 26 July 2020 [39,40]. The second COVID-19 epidemic wave in South Africa resurged on the $1^{\text {st }}$ of December 2020 with 212529 peak Active COVID-19 cases and a peak date of 15 January 2021 [41]. On the 27th of April 2021, the third COVID-19 epidemic wave in South Africa resurged. The third COVID-19 epidemic wave in South Africa had two observed peaks on the $10^{\text {th }}$ of July and on the $26^{\text {th }}$ of August 2021 with 211052 and 169039 Active COVID-19 cases respectively lasting up to the end of September 2021 [2]. The response by the Government of South Africa to the COVID-19 epidemic was the establishment of a National Coronavirus Command Council to oversee the epidemic, the use of health policy measures including NPIs to try to mitigate the transmission of COVID-19 and the implementation of COVID-19 vaccination programmes to try to vaccinate the South African population against COVID-19 [42-47]. As of 19 September 2021, 15.8 million people have been vaccinated against COVID-19 in South Africa mainly with the Pfizer-BioNTech (Comirnaty) and the Johnson \& Johnson/Janssen COVID-19 vaccines [48].

"Globally, systems have been established and are being strengthened to detect 'signals' of potential VOIs or VOCs and assess these based on the risk posed to global public health" [21]. In South Africa, the Network for Genomics Surveillance in South Africa (NGS-SA) was formed to understand the spread of SARS-CoV-2 [49]. The NGSSA was launched in June 2020 and this consortium comprised of the National Health Laboratory Services (NHLS) 
medRxiv preprint doi: https://doi.org/10.1101/2021.10.22.21265316; this version posted October 25, 2021. The copyright holder for this preprint (which was not certified by peer review) is the author/funder, who has granted medRxiv a license to display the preprint in perpetuity.

It is made available under a CC-BY 4.0 International license.

and associated academic institutions, the National Institute for Communicable Diseases (NICD), KZN Research Innovation \& Sequencing Platform (KRISP), Stellenbosch University (SU), University of Cape Town (UCT). University of Free State (UFS), University of Pretoria (UP), University of KwaZulu-Natal (UKZN), and the South African National Bioinformatics Institute (SANBI) [50]. In the first COVID-19 epidemic wave in South Africa, 16 SARS-CoV-2 lineages specific to South Africa were identified from 1365 high-quality whole genomes [49]. From these 16 lineages, three main clusters (B.1.1.54, B.1.1.56, and C.1 SARS-CoV-2 lineages) were identified to have caused approximately $42 \%$ of the SARS-CoV-2 infections in South Africa [49]. Another sub lineage specific to South Africa was the B.1.106 lineage that emerged in the Kwa-Zulu Natal province in a nosocomial outbreak during the first COVID-19 epidemic wave [49]. The prevalence of this sub-lineage decreased as a result of control measures [49,51]. The C.I lineage (first identified C lineage of SARS-CoV-2) was the most geographically spread lineage in South Africa's first COVID-19 epidemic wave [49]. Before the resurgence of the second COVID-19 epidemic wave in South Africa, the Beta (B.1.351, B1.351.2, B.1.351.3 lineages) SARSCoV-2 VOC (formerly GR/501Y.V2) was identified in an analysis of 2704 South African SARS-CoV-2 genotypes (samples up to $14^{\text {th }}$ of December 2020) from the GISAID database. The Beta (B.1.351 lineage) SARSCoV-2 VOC was detected in samples collected in the months of October 2020 [52]. The Beta (B.1.351 lineage) SARS-CoV-2 VOC had 9 mutations in the Spike protein at L18F, D80A, D215G, R246I, K417N, E484K, N501Y, D614G, and A701V. Three of those mutations (K417N, E484K, N501Y)) were located in the RBD. The Beta SARS-CoV-2 lineage became the dominant lineage in South Africa's second COVID-19 epidemic wave rapidly replacing the three main clusters (B.1.1.54, B.1.1.56 and C.1 SARS-CoV-2 lineages) identified during the first COVID-19 epidemic wave [52]. A study by [53] showed that the Beta SARS-CoV-2 lineage required a halfmaximal inhibitory concentration $\left(I C_{50}\right) 6$ to 200 fold higher than the lineages identified in the first wave. Indicating that the Beta SARS-CoV-2 variant may escape neutralising antibody response developed from prior infections [53]. In the resurgence of the third COVID-19 epidemic wave in South Africa, four SARS-CoV variants were identified which were the Alpha, Beta, Eta, and Delta SARS-CoV variants. Genomic data for South African samples, identified $65 \%$ of 1147 whole genomes from May 2021 to be the Beta SARS-CoV-2 variant. The Alpha, Delta, and Eta SARS-CoV-2 variants accounted for $6 \%, 16 \%$, and $1 \%$ of those samples respectively. In June 2021, with 2931 genetic sequences in that period, the Delta SARS-CoV-2 variant had become the dominant variant in samples collected in South Africa at $66 \%$ while the Beta and Alpha SARS-CoV-2 variants accounted for 16 $\%$ and $4 \%$ respectively [54]. By the end of South Africa's third COVID-19 epidemic wave in September 2021, the Delta SARS-CoV-2 variant accounted for $96 \%$ of the 186 whole-genome sampled in that period while the C1.2 SARS-CoV-2 lineage account for $1 \%$ of those samples [54]. The C1.2 SARS-CoV-2 lineage was a new South Africa specific SARS-CoV-2 lineage identified in South African samples in the month of May 2021 and evolved from the C.1 SARS-CoV-2 lineage. The C.1.2 SARS-CoV-2 lineage had several mutations with multiple substitutions (R190S, D215G, N484K, N501Y, H655Y and T859N) and deletions (Y144del, L242-A243del) in the Spike protein. There was also an accumulation of additional mutation $(\mathrm{C} 136 \mathrm{~F}, \mathrm{Y} 449 \mathrm{H}$ and $\mathrm{N} 679 \mathrm{~K})$ in the C.1.2 SARS-CoV-2 thought to likely impact neutralisation sensitivity. The C.1.2 has been detected across the majority of South African provinces and in seven other countries [55].

The evolution of SARS-CoV-2 has played a significant role in the resurgence of COVID-19 epidemic waves in South Africa and across the globe. South Africa has a unique observation of the evolution of SARS-CoV-2, with distinct SARS-CoV-2 lineages dominating certain epidemic periods. This unique observation allows for an investigation of the detected SARS-CoV-2 lineages' impact on COVID-19 transmissibility and severity through analysis of epidemiological data. In this study, inferential statistical analysis was conducted on South African COVID-19 epidemiological data to investigate the impact of SARS-CoV-2 lineages in the South African COVID19 epidemiology. 
medRxiv preprint doi: https://doi.org/10.1101/2021.10.22.21265316; this version posted October 25, 2021. The copyright holder for this preprint (which was not certified by peer review) is the author/funder, who has granted medRxiv a license to display the preprint in

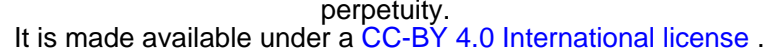

\section{Methodology}

The general methodology in this study involved the collation of South African COVID-19 epidemiological data, the regression and normalisation of the epidemiological data, and inferential statistical analysis.

\subsection{Collation of South African COVID-19 Epidemiological Data.}

\subsubsection{South African COVID-19 Testing and Reported Case Data}

South African COVID-19 reported case data (Cumulative and Daily COVID-19 Cases, Recovered and Deaths) for the reporting period of 22 January 2020 to 19 September 2021 were obtained from the Johns Hopkins University (JHU) Center for Systems Science and Engineering (CSSE) COVID-19 Database [2]. While the South African COVID-19 testing data (Cumulative and Daily COVID-19 tests) were obtained from the Our World In Data project [56] for the reporting period of 14 February 2020 to 16 September 2021. COVID-19 Active cases were then calculated using Equation 1 per reported date:

\section{Active Cases $=$ Cumulative Cases - Cumulative Recovered Cases - Cumulative Deaths Equation 1}

\subsubsection{South African COVID-19 Hospitalisation and Excess (Natural) Deaths Data}

South African COVID-19 hospitalisation data were obtained from the National Institute for Communicable Diseases (NICD) DATCOV surveillance system for the period of 24 May 2020 to 19 September 2021. The NICD sentinel hospital surveillance system was designed to monitor and describe trends of COVID-19 hospitalizations and the epidemiology of hospitalized patients in South Africa [57]. The South African COVID-19 hospitalisation data was composed of the Number of Facilities Reporting, Admission Status Data (Daily COVID-19 Hospital Admitted Cases, Hospitalised in High Care, Intensive Care Unit, Isolation Ward, On Oxygen and Ventilator), Cumulative COVID-19 Admission Age Profile, Cumulative COVID-19 Hospital Deaths Age Profile and Cumulative COVID-19 Patients Discharged Alive. The COVID-19 Hospital Daily Discharge Rate (DR) and Case Fatality Rate (CFR) were then calculated based on the methodology in [58]. First, the COVID-19 daily patient discharge and deaths were calculated using Equation 2 and Equation 3 respectively:

$$
\begin{array}{r}
\text { Daily Discharge }(n)_{i+1}=\text { Discharged Alive }(n)_{i+1}-\text { Discharged Alive }(n)_{i} \\
\text { Daily Deaths }(n)_{i+1}=\operatorname{Died}(n)_{i+1}-\text { Died }(n)_{i} \quad \text { Equation } 3
\end{array}
$$$$
\text { Equation } 2
$$

Where $\mathrm{n}$ is the number of patients and $\mathrm{i}$ is the reported case date. Then the COVID-19 Hospital Daily Discharge Rate (DR) and Case Fatality Rate (CFR) were then calculated using Equation 4 and Equation 5 respectively.

$$
\begin{aligned}
\mathrm{DR}_{i+1} & =\frac{\text { Daily Discharge }(n)_{i+1}}{\text { Admitted }_{i+1}} \\
\operatorname{CFR}_{i+1} & =\frac{{\text { Daily Deaths }(n)_{i+1}}_{\text {Admitted }_{i+1}}}{}
\end{aligned}
$$

Equation 4

\section{Equation 5}

Where $\mathrm{n}$ is the number of patients and $\mathrm{i}$ is the reported case date. Excess mortality is an account of deaths from all causes relative to expected deaths based on previous trends/observations. Excess mortality/deaths allow for accounting for miscounted or underreported COVID-19 Deaths and indirect Deaths related to the COVID-19 pandemic [59]. South African Weekly Natural and Excess (Natural) Deaths were obtained from the South African Medical Research Council (SAMRC) [60] for the reporting period of 29 December 2019 to 18 September 2021. The Weekly Unreported Excess Deaths (Natural) to COVID-19 Death Ratio (ECDR) was then calculated based on the methodology in [58] using Equation 6:

$$
\mathrm{ECDR}_{i+1}=\frac{\text { Excess Deaths }(\text { Natural }) \text { i-Weekly Reported COVID-19 Deaths }}{i}
$$

Equation 6

Where $\mathrm{i}$ is the Weekly Reported Date. 
medRxiv preprint doi: https://doi.org/10.1101/2021.10.22.21265316; this version posted October $25,2021$. The copyright holder for this preprint (which was not certified by peer review) is the author/funder, who has granted medRxiv a license to display the preprint in perpetuity.

It is made available under a CC-BY 4.0 International license.

\subsubsection{Stratification of South African COVID-19 Epidemiological Data}

To draw inferential comparisons regarding the impact of the evolution of SARS-CoV-2 in the South African COVID-19 epidemiology, the collated South African COVID-19 epidemiological data in Section 2.1.1 and 2.1.2 was stratified based on the observed COVID-19 epidemic wave period 1, 2 and 3 in South Africa. Based on a review of $[49,52,54]$, Table 1 was generated summarising the Sotuh African (SA) SARS-CoV-2 lineage clusters observed in the genomic data in the observed COVID-19 epidemic wave periods. The South African COVID-19 epidemic wave period 1, 2 and 3 were classed as reported case data in the period of 5 March 2020 to 30 September 2020, 01 October 2020 to 26 April 2021 and 27 April 2021 to 19 September 2021 respectively. The labels of stratified variables were given a reference of "_1", “_2", “_3" for the three respectively epidemic periods. By this stratification, the cluster of lineages identified in Table 1 was assumed to be the SARS-COV-2 lineages resulting in the respective COVID-19 epidemic waves in South Africa. For Cumulative Epidemiological Data (South African Cumulative COVID-19 Admission Age Profile, Cumulative COVIID-19 Hospital Deaths Age Profile and Cumulative COVID-19 Patients Discharged Alive) the data was adjusted using Equation 7 to remove the cumulative data from the previous COVID-19 epidemic period.

\section{Cumulative Epidemic Variable_Adj $(n)_{i}=$ Cumulative Epidemic Variable $(n)_{i}-$ Cumulative Epidemic Variable $(n)_{j} \quad$ Equation 7}

Where $\mathrm{n}$ is the number of patients, $\mathrm{i}$ is the reported date and $\mathrm{j}$ is the last reported date of the previous COVID-19 epidemic period. The stratification of data in this study was done by splitting the data using the epidemic period variable in the IBM SPSS STATISTICS 27 Software. 
Table 1: SARS-CoV-2 lineages identified in genome samples obtained from patients with laboratory-confirmed COVID-19 for the three observed South African COVID-19 epidemic wave periods. Data extracted from [49,52,54]

\begin{tabular}{|c|c|c|c|c|c|c|c|c|c|}
\hline COVID-19 Epidemic Wave & Epidemic Period & Genome Samples & Genome Sampling Period & $\begin{array}{c}\begin{array}{c}\text { SARS-CoV-2 Lineages in } \\
\text { Samples }\end{array} \\
\text { (a) }\end{array}$ & $\begin{array}{l}\text { SARS-CoV-2 Lineages in } \\
\text { Epidemic Period }\end{array}$ & $\begin{array}{c}\text { SA Specific SARS-CoV-2 } \\
\text { Lineages }\end{array}$ & \begin{tabular}{|c|} 
Emerging Dominant \\
SARS-COV-2 \\
Lineages \\
Spatiotemporal \\
Phylogeographic \\
\end{tabular} & \begin{tabular}{|c|} 
Emerging \\
Dominant SARS- \\
COV-2 Lineages in \\
Samples $(\%)$ \\
\end{tabular} & $\begin{array}{c}\text { SARS-CoV-2 Lineage } \\
\text { Cluster }\end{array}$ \\
\hline 1 & 2020/03/05-2020/09/30 & 1365 & $2020 / 03 / 06-2020 / 08 / 26$ & $\begin{array}{l}\text { A. B, B.1, B.1.1, B.1.1.1, } \\
\text { B.1.1.10, B.1.1.26, B.1.1.34, } \\
\text { B.1.1.35, B.1.1.40, B.1.1.52, } \\
\text { B.1.1.53, B.1.1.54, B.1.1.56, } \\
\text { B.1.1.57, B.1.1.62, B.1.1.64, } \\
\text { B.1.1.66, B.1.1.67, B.1.1.75, } \\
\text { B.1.106, B.1.132, B.1.1.133, } \\
\text { B.1.140, B.1.144, B.1.23, } \\
\text { B.1.35, B.1.5, B.1.5.16, } \\
\text { B.1.5.19, B.1.5.22, B.1.79, } \\
\text { B.1.8, B.1.98, B.2, B.2.1, } \\
\text { B.2.2, B.3, B.6, B.9, . .1. C.2 }\end{array}$ & \begin{tabular}{|c} 
A, B, B.1, B.1.1, B.1.1.1, B.1.1.10, \\
B.1.1.26, B.1.1.34, B.1.1.35, \\
B.1.1.40, B.1.1.52, B.1.1.53, \\
B.1.1.54, B.1.1.56, B.1.1.57, \\
B.1.1.62, B.1.1.64, B.1.1.66, \\
B.1.1.67, B.1.1.75, B.1.106, \\
B.1.132, B.1.133, B.1.140, \\
B.1.144, B.1.23, B.1.35, B.1.5, \\
B.1.5.16, B.1.5.19, B.1.5.22, \\
B.1.79, B.1.8, B.1.98, B.2, B.2.1, \\
B.2.2, B.3, B.6, B.9, C.1, C.2
\end{tabular} & $\begin{array}{c}\text { B.1.1.34, B.1.1.40, } \\
\text { B.1.1.52, B.1.1.53, } \\
\text { B.1.1.54, B.1.1.56, } \\
\text { B.1.1.57, B.1.1.62, } \\
\text { B.1.1.66, B.1.106, B.1.133, } \\
\text { B.1.144, B.1.5.16, B.1.5.19, } \\
\text { C.1, C.2 }\end{array}$ & \begin{tabular}{|c|} 
B.1.1.106 (April 2020), \\
B.1.1.54 (poor \\
temporal signaling), \\
B.1.1.56 (mid-March \\
2020 \\
(95\% highest posterior \\
density (HPD) 2020- \\
02-15 to 2020-03-30)), \\
C.1 (early May 2020 \\
(95\% HPD 2020-04- \\
24 \\
to 2020-05-24))
\end{tabular} & $\begin{array}{c}\text { B.1.1.54, B.1.1.56, } \\
\text { C.1 (42.1\% of total } \\
\text { genomes) }\end{array}$ & 1 \\
\hline 2 & 2020/10/01-2021/04/26 & 2573 & $2020 / 03 / 05-2020 / 12 / 10$ & 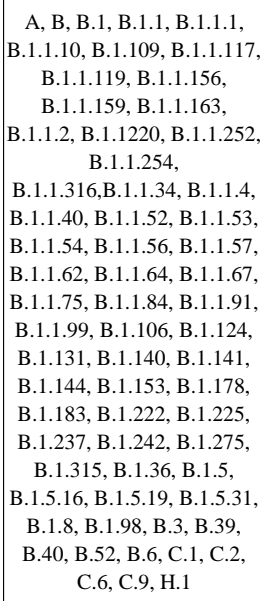 & \begin{tabular}{|c} 
B.1,B.1.1.B.1.1.119, B.1.1.54, \\
B.1.1.56, C.1, B.1.351, B.1.1.156, \\
B.1.1.252, B.1.1.254, B.1.1.34, \\
B.1.1.57, B.1.1.220, B.1.144, \\
B.1.237, B.1.351, B.1.5, B.1.5.19, \\
B.1.5.31, C.2, C.9, B.1.106
\end{tabular} & \begin{tabular}{|c|} 
B.1.1.34, B.1.1.54, \\
B.1.1.56, C.1, B.1.351, \\
B.1.1.57, B.1.106, B.1.144, \\
B.1.5.19, C.2
\end{tabular} & $\mid \begin{array}{c}\text { B.1.351 (early August } \\
\text { (95\% highest posterior } \\
\text { density ranging } \\
\text { from the middle of } \\
\text { July to the end of } \\
\text { August 2020)) }\end{array}$ & \begin{tabular}{|c|} 
B.1.351 \\
(Approximately 90 \\
\% of Samples by \\
End of November \\
2020)
\end{tabular} & 2 \\
\hline 3 & 2021/04/27-2021/09/19 & 9462 & 2021/05-2021/09 & $\begin{array}{c}\text { B.1.351, B.1.617.1, } \\
\text { B.1.617.2, B.1.525, B.1.1.7, } \\
\text { C.1.2, Other (1.74 \%), } \\
\text { unassiged (5.20\%) }\end{array}$ & $\begin{array}{l}\text { B.1.1.351, B.1.617.1, B.1.617.2, } \\
\text { B.1.525, B.1.1.7, C.1.2 }\end{array}$ & B.1.351, C.1.2 & & \begin{tabular}{|c|} 
B.1.617.2 \\
(Approximately \\
Over 65\% in June, \\
$85 \%$ in July and \\
over 90\% of \\
samples in August \\
and September \\
2021 ) \\
\end{tabular} & 3 \\
\hline
\end{tabular}




\subsection{Regression of South African COVID-19 Epidemiological Data.}

In an epidemic, several factors influence the outcome of the observed epidemic. This includes testing, reporting capacity and population movement for a human to human infectious diseases such as COVID-19 (disease daily effective contact rate) [61]. For inferential statistical comparative analysis to be conducted between epidemiological data from different epidemic periods, the covariance of the epidemiological data needs to be accounted for in the analysis. Covariance is the measure of the combined variability of two random variables [62]. The independent variable in the covariance is a predictor variable influencing the outcome of a dependent variable.

\subsubsection{Linear Regression of COVID-19 Daily Tests and Cases}

[58] showed that there was a positive correlation between South African COVID-19 Daily Tests and Cases in the first COVID-19 epidemic period. The South African COVID-19 daily testing was also shown not to be consistent throughout the period. To understand the covariance between South African COVID-19 daily tests and cases, Descriptive Statistical Analysis, Bivariate Analysis using the Two-tailed Pearson and Spearman tests and Analysis of Variance using the Univariate General Linear Model was conducted on the COVID-19 Daily Tests and Cases (Dependent Variable) using the IBM SPSS STATISTICS 27 Software for the three COVID-19 epidemic periods. Table 2 shows that the mean COVID-19 daily tests in the first, second and third South African COVID-19 epidemic wave period were $20575 \pm 14062,31046 \pm 14115$ and $46822 \pm 18460$ respectively. The value of these means indicates the difference in testing capacity in the three epidemic periods. The Skewness values shown in Table 2 indicate that the normal distribution of the South African COVID-19 Daily Tests and Cases were positively skewed with the COVID-19 Daily Cases being more skewed than the Daily Tests. The skewness of COVID-19 Daily Cases was expected considering that the distribution is lognormal (Galton distribution) with differential (calculus) relations to normally distributed random variables such as the COVID-19 effective daily contact rate in this probability space. The application of differentials to model COVID-19 using random variables in stochastic COVID-19 epidemiological modelling was shown to be effective in modelling the COVID-19 epidemiology in South Africa [58,63,64].

Table 2: Statistical Sample Number (N), Range, Minimum, Maximum, Mean, Standard Deviation (Std Deviation), Variance, Coefficient of Skewness, Kurtosis Coefficient of COVID-19 Daily Tests, New Cases in the First, Second and Third COVID-19 Epidemic Wave in South Africa (Descriptive Statistics)

\begin{tabular}{|c|c|c|c|c|c|c|c|c|c|c|c|c|c|}
\hline \multicolumn{14}{|c|}{ Descriptive Statistics } \\
\hline \multirow{2}{*}{\multicolumn{2}{|c|}{ COVID-19_Epidemic_Wave }} & \multirow{2}{*}{\begin{tabular}{|c|}
$\mathrm{N}$ \\
Statistic
\end{tabular}} & \multirow{2}{*}{\begin{tabular}{|l|} 
Range \\
Statistic
\end{tabular}} & \multirow{2}{*}{\begin{tabular}{|l|} 
Minimum \\
Statistic \\
\end{tabular}} & \multirow{2}{*}{\begin{tabular}{|l} 
Maximum \\
Statistic
\end{tabular}} & \multicolumn{2}{|c|}{ Mean } & \multirow{2}{*}{$\frac{\text { Std. Deviation }}{\text { Statistic }}$} & \multirow{2}{*}{\begin{tabular}{|l|} 
Variance \\
Statistic
\end{tabular}} & \multicolumn{2}{|c|}{ Skewness } & \multicolumn{2}{|c|}{ Kurtosis } \\
\hline & & & & & & Statistic & Std. Error & & & Statistic & Std. Error & Statistic & Std. Error \\
\hline & COVID-19_Daily_Tests & 203 & 56659 & 4 & 56663 & 20575 & 987 & 14062 & 197739959 & 0.474 & 0.171 & -0.590 & 0.340 \\
\hline 1 & $\begin{array}{c}\text { COVID- } \\
\text { 19_Daily_New_Cases }\end{array}$ & 253 & 13944 & 0 & 13944 & 2665 & 235 & 3736 & 13958924 & 1.620 & 0.153 & 1.564 & 0.305 \\
\hline & Valid N (listwise) & 203 & & & & & & & & & & & \\
\hline & COVID-19_Daily_Tests & 201 & 66765 & 10402 & 77167 & 31046 & 996 & 14115 & 199227395 & 1.164 & 0.172 & 1.179 & 0.341 \\
\hline 2 & $\begin{array}{c}\text { COVID- } \\
\text { 19_Daily_New_Cases }\end{array}$ & 208 & 21543 & 437 & 21980 & 4336 & 349 & 5034 & 25340444 & 1.793 & 0.169 & 2.386 & 0.336 \\
\hline & Valid N (listwise) & 201 & & & & & & & & & & & \\
\hline & COVID-19_Daily_Tests & 119 & 116166 & 16194 & 132360 & 46822 & 1692 & 18460 & 340760831 & 1.060 & 0.222 & 2.884 & 0.440 \\
\hline 3 & $\begin{array}{c}\text { COVID- } \\
\text { 19_Daily_New_Cases }\end{array}$ & 127 & 26485 & 0 & 26485 & 9459 & 537 & 6047 & 36560682 & 0.418 & 0.215 & $\mid-0.417$ & 0.427 \\
\hline & Valid N (listwise) & 119 & & & & & & & & & & & \\
\hline
\end{tabular}

Table 3 shows that the Pearson (Spearman) Correlation Coefficients between COVID-19 Daily Tests (Independent Variable) and COVID-19 Daily Cases (Dependent Variable) in the First, Second and Third COVID19 Epidemic Wave in South Africa were 0.910 (0.955), 0.877 (0.751) and 0.821 (0.867) respectively. The values of the Pearson (Spearman) Correlation Coefficients observed indicate a strong positive correlation between COVID-19 Daily Tests and Cases with p-values more than $95 \%$ confidence. The F values are shown in Table 4 for the Mean Square Regression and Residual between COVID-19 Daily Tests (Independent Variable) and COVID-19 Daily Cases (Dependent Variable) indicate that the residual error between the linear predicted value and the actual values are relatively small. These results in Section 2.2.1 show that COVID-19 Daily Cases in South Africa were dependent on the COVID-19 Daily test with a positive linear relationship based on the Standardized Coefficients shown in Table 5. 
medRxiv preprint doi: https://doi.org/10.1101/2021.10.22.21265316; this version posted October 25, 2021. The copyright holder for this preprint (which was not certified by peer review) is the author/funder, who has granted medRxiv a license to display the preprint in

perpetuity.
It is made available under a CC-BY 4.0 International license.

Table 3: Pearson and Spearman's Correlation Coefficients and P-Values (Sig. (2-tailed)) between COVID-19 Daily Tests (Independent Variable) and COVID-19 Daily New Cases (Dependent Variable) in the First, Second and Third COVID-19 Epidemic Wave in South Africa (Correlations)

\begin{tabular}{|c|c|c|c|c|c|c|}
\hline \multicolumn{2}{|c|}{ COVID-19_Epidemic_Wave } & N & Pearson Correlation & Sig. (2-tailed) & $\begin{array}{c}\text { Spearman's rho } \\
\text { Correlation Coefficient }\end{array}$ & Sig. (2-tailed) \\
\hline 1 & COVID-19_Daily_Tests & 203 & $.910^{*}$ & $9.94 \mathrm{E}-79$ & $.955^{*}$ & $1.96 \mathrm{E}-108$ \\
\hline 2 & COVID-19_Daily_Tests & 201 & $.877^{*}$ & $2.69 \mathrm{E}-65$ & $.751^{*}$ & $8.92 \mathrm{E}-38$ \\
\hline 3 & COVID-19_Daily_Tests & 119 & $.821^{*}$ & $3.03 \mathrm{E}-30$ & $.867^{*}$ & $3.15 \mathrm{E}-37$ \\
\hline \multirow{2}{*}{${ }^{* \star}$. Correlation is significant at the 0.01 level (2-tailed). } & \multicolumn{5}{|c|}{ a. Dependent Variable: COVID-19_Daily_New_Cases } \\
\hline
\end{tabular}

Table 4: Sum of Squares, Degrees of Freedom (Df, Mean Square, F values between Mean Square Regression and Residual $(F)$, between COVID-19 Daily Tests (Independent Variable) and COVID-19 Daily New Cases (Dependent Variable) in the First, Second and Third COVID-19 Epidemic Wave in South Africa (Analysis of Variance (ANOVA))

\begin{tabular}{|c|c|c|c|c|c|c|}
\hline \multicolumn{7}{|c|}{ ANOVA $^{a}$} \\
\hline \multicolumn{2}{|c|}{ COVID-19_Epidemic_Wave } & Sum of Squares & $d f$ & Mean Square & $\mathrm{F}$ & Sig. \\
\hline \multirow{3}{*}{1} & Regression & 2548543000 & 1 & 2548543000 & 967 & $.000^{\mathrm{b}}$ \\
\hline & Residual & 529940020 & 201 & 2636518 & & \\
\hline & Total & 3078483020 & 202 & & & \\
\hline \multirow{3}{*}{2} & Regression & 4024599374 & 1 & 4024599374 & 664 & $.000^{\mathrm{b}}$ \\
\hline & Residual & 1206837402 & 199 & 6064510 & & \\
\hline & Total & 5231436776 & 200 & & & \\
\hline \multirow{3}{*}{3} & Regression & 2999260614 & 1 & 2999260614 & 242 & $.000^{\mathrm{b}}$ \\
\hline & Residual & 1451354776 & 117 & 12404742 & & \\
\hline & Total & 4450615390 & 118 & & & \\
\hline \multicolumn{7}{|c|}{ a. Dependent Variable: COVID-19_Daily_New_Cases } \\
\hline & b. Predicto & (Constant), CO & VID-1 & _Daily_Tests & & \\
\hline
\end{tabular}

Table 5: Unstandardized Coefficients (B, Std. Error), Standardized Coefficients (Beta), $t$-calculated ( $t$ ), p-value calculated (Sig.) and $95.0 \%$ Confidence Interval for B between COVID-19 Daily Tests (Independent Variable) and COVID-19 Daily New Cases (Dependent Variable) in the First, Second and Third COVID-19 Epidemic Wave in South Africa (Coefficients)

\begin{tabular}{|c|c|c|c|c|c|c|c|c|}
\hline \multicolumn{9}{|c|}{ Coefficients $^{a}$} \\
\hline \multirow{2}{*}{\multicolumn{2}{|c|}{ COVID-19_Epidemic_Wave }} & \multicolumn{2}{|c|}{$\begin{array}{c}\text { Unstandardized } \\
\text { Coefficients } \\
\end{array}$} & \multirow{2}{*}{\begin{tabular}{|c|}
$\begin{array}{c}\text { Standardized } \\
\text { Coefficients }\end{array}$ \\
Beta \\
\end{tabular}} & \multirow{2}{*}{$t$} & \multirow{2}{*}{ Sig. } & \multicolumn{2}{|c|}{$\begin{array}{c}95,0 \% \text { Confidence Interval } \\
\text { for B }\end{array}$} \\
\hline & & B & Std. Error & & & & Lower Bound & Upper Bound \\
\hline \multirow{2}{*}{1} & (Constant) & -1878 & 202 & & -9.3 & 2.73E-17 & -2277 & -1479 \\
\hline & COVID-19_Daily_Tests & 0.253 & 0.008 & 0.910 & 31.1 & 9.94E-79 & 0.237 & 0.269 \\
\hline \multirow{2}{*}{2} & (Constant) & -5490 & 421 & & -13.1 & $1.53 \mathrm{E}-28$ & -6320 & -4661 \\
\hline & COVID-19_Daily_Tests & 0.318 & 0.012 & 0.877 & 25.8 & 2.69E-65 & 0.293 & 0.342 \\
\hline \multirow{2}{*}{3} & (Constant) & -3443 & 883 & & -3.90 & 1.62E-04 & -5193 & -1694 \\
\hline & COVID-19_Daily_Tests & 0.273 & 0.018 & 0.821 & 15.5 & 3.03E-30 & 0.238 & 0.308 \\
\hline
\end{tabular}


medRxiv preprint doi: https://doi.org/10.1101/2021.10.22.21265316; this version posted October 25, 2021. The copyright holder for this preprint (which was not certified by peer review) is the author/funder, who has granted medRxiv a license to display the preprint in perpetuity.

It is made available under a CC-BY 4.0 International license.

\subsubsection{Linear Regression of Number of Reporting Hospitals, COVID-19 Active and Hospitalised Cases}

The NICD DATCOV surveillance system in South Africa only started publishing reports on the reporting date of 24 May 2020 thus data from 5 March 2020 to 23 May 2020 in the first COVID-19 epidemic wave period is missing. Data from 9 October 2020 to 26 October 2020 in the second COVID-19 epidemic wave period was also missing. The number of hospitals reporting to the NICD DATCOV surveillance system in South Africa' first COVID-19 epidemic wave period was initially 204 facilities and the facilities increased to 551 by the end of this period. In South Africa's second and third COVID-19 epidemic wave periods, the facilities reporting by the end of these periods were 646 and 664 respectively. To understand the covariance between South African COVID-19 Active Cases, Number of Facilities Reporting to the NICD DATCoV surveillance system and COVID-19 Hospital Admitted Cases (Dependent Variable), Bivariate Analysis using the Two-tailed Pearson and Spearman tests and Analysis of Variance using the Univariate General Linear Model was conducted on these variables using the IBM SPSS STATISTICS 27 Software for the three COVID-19 epidemic periods. Table 6 and Table 7 show that the Pearson (Spearman) Correlation and Standardized Coefficients between Facilities Reporting to NICD DATCoV (Independent Variable) and COVID-19 Hospital Admitted Cases (Dependent Variable) in the First, Second and Third COVID-19 Epidemic Wave in South Africa were 0.336 (0.391), 0.136 (-0.260), 0.948 (0.881) and 0.271, $0.193,0.623$ respectively. The values of the Standardized Coefficients, Pearson and Spearman's Correlation Coefficients observed indicate a moderate positive correlation between the Number of Facilities Reporting to NICD DATCoV and COVID-19 Hospital Admitted Cases in the first and second epidemic period. A strong positive correlation for the third epidemic period was observed. Table 6 and Table 7 also show that the Pearson (Spearman) Correlation and Standardized Coefficients between COVID-19 Active Cases (Independent Variable) and COVID-19 Hospital Admitted Cases (Dependent Variable) in the First, Second and Third COVID-19 Epidemic Wave in South Africa were 0.932 (0.959), 0.873 (0.875), 0.904 (0.850) and 0.913, 0.885, 0.404 respectively.

Table 6: Pearson and Spearman's Correlation Coefficients and P-Values (Sig. (2-tailed)) between Number of Facilities Reporting to the NICD DATCoV System (Independent Variable), COVID-19 Active Cases (Covariant Variable) and COVID19 Hospital Admitted Cases (Dependent Variable) in the First, Second and Third COVID-19 Epidemic Wave in South Africa (Correlations)

\begin{tabular}{|c|c|c|c|c|c|c|}
\hline \multicolumn{7}{|c|}{ Correlations $^{\mathrm{a}}$} \\
\hline \multicolumn{2}{|r|}{ COVID-19_Epidemic_Wave } & $\mathrm{N}$ & Pearson Correlation & Sig. (2-tailed) & $\begin{array}{c}\text { Spearman's rho } \\
\text { Correlation Coefficient }\end{array}$ & Sig. (2-tailed) \\
\hline \multirow{2}{*}{ 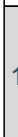 } & \begin{tabular}{|c|} 
Facilities_Reporting_To_To \\
NICD_DATCoV
\end{tabular} & 126 & $.336^{* *}$ & 1.17E-04 & $.391^{* *}$ & $5.92 \mathrm{E}-06$ \\
\hline & COVID-19_Active_Cases & 126 & $.932^{* *}$ & $1.20 \mathrm{E}-56$ & $.959^{* *}$ & $1.02 \mathrm{E}-69$ \\
\hline \multirow[b]{2}{*}{2} & $\begin{array}{c}\text { Facilities_Reporting_To_T } \\
\text { NICD_DATCoV }\end{array}$ & 187 & 0.136 & $6.27 \mathrm{E}-02$ & $-.260^{* *}$ & 3.27E-04 \\
\hline & COVID-19_Active_Cases & 187 & $.873^{* *}$ & $1.62 \mathrm{E}-59$ & $.875^{* *}$ & $3.62 \mathrm{E}-60$ \\
\hline 3 & \begin{tabular}{|c|} 
Facilities_Reporting_To_To \\
NICD_DATCoV
\end{tabular} & 127 & $.948^{* *}$ & $8.51 \mathrm{E}-64$ & $.881^{* *}$ & 2.26E-42 \\
\hline & COVID-19_Active_Cases & 127 & $.904^{* *}$ & $5.04 \mathrm{E}-48$ & $.850^{* *}$ & $1.22 \mathrm{E}-36$ \\
\hline & $\begin{array}{l}\text { * Correlation is significant } \\
\text { at the } 0.01 \text { level (2-tailed). }\end{array}$ & \multicolumn{5}{|c|}{ a. Dependent Variable: COVID-19_Hospital_Admitted_Cases } \\
\hline
\end{tabular}

The values of the Standardized, Pearson and Spearman's Correlation Coefficients observed indicate a strong positive correlation between COVID-19 Active and Hospital Admitted Cases. This result was expected based on probability theory. An increase in COVID-19 active cases increases the probability of stochastic proportions of COVID-19 severity including severe and critical COVID-19 thus higher hospitalisations. This correlation was also well demonstrated by stochastic COVID-19 epidemiological models such as in $[58,63,64]$. 
Table 7: Unstandardized Coefficients (B, Std. Error), Standardized Coefficients (Beta), $t$-calculated ( $t$ ), p-value calculated (Sig.) and $95.0 \%$ Confidence Interval for B between Number of Facilities Reporting to the NICD DATCoV System (Independent Variable), COVID-19 Active Cases (Covariant Variable) and COVID-19 Hospital Admitted Cases (Dependent Variable) in the First, Second and Third COVID-19 Epidemic Wave in South Africa (Coefficients)

\begin{tabular}{|c|c|c|c|c|c|c|c|c|c|}
\hline \multicolumn{10}{|c|}{ Coefficients $^{a}$} \\
\hline & & \multirow{2}{*}{ COVID-19_Epidemic_Wave } & \multicolumn{2}{|c|}{ Unstandardized Coefficients } & \multirow{2}{*}{\begin{tabular}{|c|}
$\begin{array}{c}\text { Standardized } \\
\text { Coefficients }\end{array}$ \\
Beta \\
\end{tabular}} & \multirow{2}{*}{$\mathrm{t}$} & \multirow{2}{*}{ Sig. } & \multicolumn{2}{|c|}{$\begin{array}{c}95,0 \% \text { Confidence Interval } \\
\text { for B }\end{array}$} \\
\hline & & & $\mathrm{B}$ & Std. Error & & & & Lower Bound & Upper Bound \\
\hline \multirow{2}{*}{1} & \multirow{3}{*}{1} & (Constant) & -69.4 & 171 & & -0.407 & 0.685 & -407 & 268 \\
\hline & & Facilities_Reporting_To_NICD_DATCoV & 5.55 & 0.444 & 0.271 & 12.5 & $1.16 \mathrm{E}-23$ & 4.68 & 6.43 \\
\hline & & COVID-19_Active_Cases & 0.036 & 0.001 & 0.913 & 42.1 & $6.30 \mathrm{E}-75$ & 0.034 & 0.037 \\
\hline \multirow{3}{*}{2} & \multirow{3}{*}{1} & (Constant) & -24246 & 4729 & & -5.13 & 7.42E-07 & -33577 & -14916 \\
\hline & & Facilities_Reporting_To_NICD_DATCoV & 43.9 & 7.52 & 0.193 & 5.83 & 2.39E-08 & 29.0 & 58.7 \\
\hline & & COVID-19_Active_Cases & 0.069 & 0.003 & 0.885 & 26.7 & $3.02 E-65$ & 0.064 & 0.074 \\
\hline & \multirow{3}{*}{1} & (Constant) & -219210 & 11232 & & -19.5 & $1.28 \mathrm{E}-39$ & -241442 & -196978 \\
\hline 3 & & Facilities_Reporting_To_NICD_DATCoV & 345 & 17.4 & 0.623 & 19.8 & $3.49 \mathrm{E}-40$ & 310 & 379 \\
\hline & & COVID-19_Active_Cases & 0.031 & 0.002 & 0.404 & 12.8 & $1.70 \mathrm{E}-24$ & 0.026 & 0.035 \\
\hline & & & lent & VID-19 & al_Adn & ses & & & \\
\hline
\end{tabular}

\subsubsection{Regression of the COVID-19 Daily Effective Contact Rate and Movement Restrictions (NPIs)}

South Africa's COVID-19 health policy response to the COVID-19 epidemic waves in South Africa was implemented in the form of National Lockdown Alert Level policies. The National Lockdown Alert Level policies were largely entry and exit screening at borders, limitations of movements and gatherings, closure/limitations of institutions and business activities, ban/limiting of alcohol and tobacco industries, isolation, quarantine of potentially infected persons, contact tracing protocols, use of personal protective equipment (PPE) and hygienic protocols [58]. In South Africa's first COVID-19 epidemic wave period the National Lockdown Alert Levels 5 (26 March to 30 April 2020), 4 (1 May to 31 May 2020),3 (I June to 17 August 2020), and 2 (18 August to 20 September 2020) were implemented [65]. In South Africa's second COVID-19 epidemic wave period the National Lockdown Adjusted Alert Levels 1 (21 September to 28 December 2020; 1 March to 30 May 2021) and 3 (29 December 2020 to 28 February 2021) were implemented. Whilst for South Africa's third COVID-19 epidemic wave period the National Lockdown Adjusted Alert Levels 2 (31 May to 15 June 2021; 13 September 2021), 3 (16 June to 27 June 2021; 26 July to 12 September 2021) and 4 (28 June to 25 July 2021) were implemented.

The daily effective contact rate is the average number of adequate contacts per infective per day. It is directly proportional to the reproductive number [61]. [58] showed the impact of NPIs particularly movement restriction on the COVID-19 daily effective contact rate in South Africa. In this study, a relationship between the community mobility of the South African population and the COVID-19 Daily Effective Contact Rate was established. [58] showed that an increase in 1 Alert Level in the South African National Lockdown Alert Levels was $30 \%$ more effective in reducing population movement and resulted in a reduction in the COVID-19 Daily Effective Contact Rate by $4.13 \%$ to $14.6 \%$ compared to the preceding Alert Level. The study also showed that the National Lockdown Alert Levels 1 and 2 had a similar impact on the population movements in the South African communities in the first COVID-19 epidemic wave period [58]. Figure 1 shows the South African community mobility in the Retail and Recreation, Grocery and Pharmacy, Parks, Transit Stations, Workplaces and Residences locations in the three COVID-19 epidemic periods. The modulus mean movement change from baseline in South African locations in the period of 26 March to 25 May 2020 for the first COVID-19 epidemic wave period were higher than those observed in the second and third COVID-19 epidemic wave periods. This period corresponds to the implementation of the National Lockdown Alert Levels 5 and 4 in the first COVID-19 epidemic wave. In the second and third COVID-19 epidemic wave periods the highest alert levels implemented were the adjusted 
medRxiv preprint doi: https://doi.org/10.1101/2021.10.22.21265316; this version posted October 25, 2021. The copyright holder for this preprint (which was not certified by peer review) is the author/funder, who has granted medRxiv a license to display the preprint in

perpetuity.
It is made available under a CC-BY 4.0 International license.

Alert Level 3 and 4 respectively. The adjustment in these Alert Levels resulted in more eased movement restrictions than its predecessors while the National Alert level 5 lockdown implemented in the first COVID-19 epidemic wave period had the hardest population movement restrictions experienced by the South African population. These differences resulted in the lower modulus mean movement change from baselines in South African locations in the second and third COVID-19 epidemic wave periods. Thus, caution must be taken when concluding the impact of SARS-CoV-2 lineages on the observed COVID-19 epidemic in South Africa as the different movement restrictions might have also had an impact.
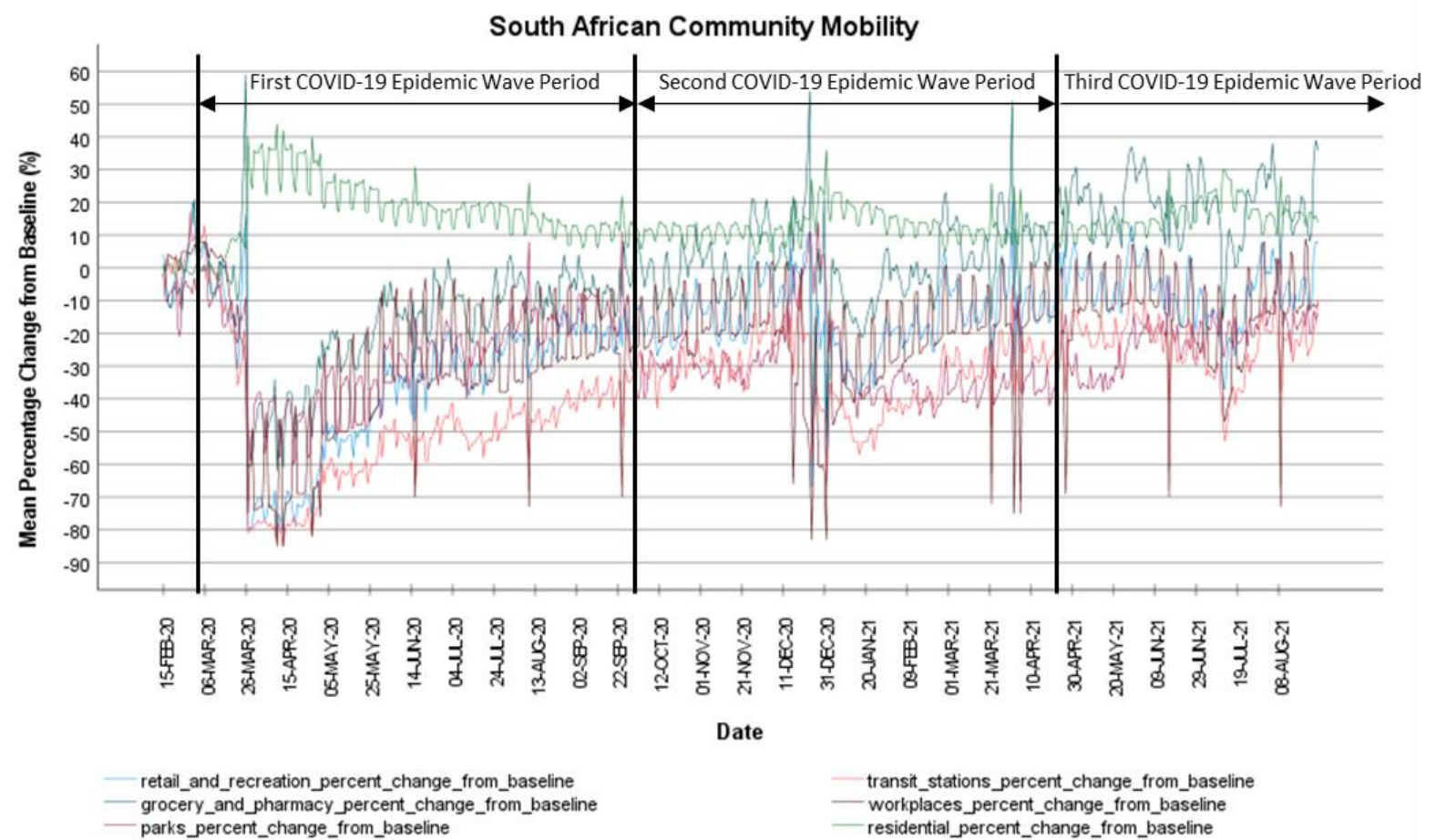

Figure 1: South African Community Google Mobility in Retail and Recreation, Grocery and Pharmacy, Parks, Transit Stations, Workplaces and Residences during the period of 2020/02/15 to 2021/08/27 [66]

\subsection{Normalisation and Inferential Statistical Analysis of South African COVID-19 Epidemiological Data}

2.3.1 Comparative Analysis on the COVID-19 Transmissibility in the South African COVID-19 Epidemic Wave Periods

Disease transmissibility is the ability for a disease to be transmitted from one individual to another through infection. The basic reproductive number $\left(\mathrm{R}_{0}\right)$ is a parameter that is largely used to describe the transmissibility of a disease. The basic reproductive number is the number of secondary infections that a primary infected person would produce in a completely susceptible population [61]. If $R_{0}$ is greater than one then the disease is in an endemic equilibrium which results in positive exponential growth in cases. If the $\mathrm{R}_{0}$ is less than 1 then the disease is in the disease-free equilibrium which results in negative exponential growth in cases. The peak of the COVID19 epidemic waves represents the turning point of the effective reproductive number. [58] showed through stochastic COVID-19 epidemiological modelling that the effective reproductive number in the first COVID-19 epidemic wave in South Africa was between 1.98 to 0.40 . The NICD conducted a modelling analysis to estimate the initial basic reproductive number in South Africa using the method in [67] and estimated that it was 1.29 (95\%CI: 1.9601.58)) during the National Lockdown Alert Level 5 rising to 1.5 by end of April 2020, 1.05 (95\% CI:1.01-1.09) during the National Lockdown Alert Level 3 between 1 June and 1 August 2020 [68].

In this study, the COVID-19 transmissibility was measured through the magnitude of mean and variance of the COVID-19 Daily and Active Cases. Considering the linear positive correlation between the COVID-19 Daily Tests and Cases, for the comparative inferential analysis of COVID-19 Daily and Active Cases between the COVID-19 epidemic wave periods a normalised parameter (COVID-19 Daily Positive Tests) was developed based on Equation 8 to normalise the variance of testing in reported cases. 
medRxiv preprint doi: https://doi.org/10.1101/2021.10.22.21265316; this version posted October 25, 2021. The copyright holder for this preprint (which was not certified by peer review) is the author/funder, who has granted medRxiv a license to display the preprint in

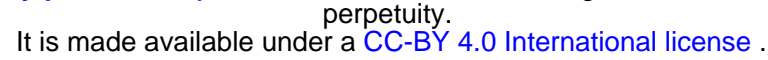

$$
\text { COVID - } 19 \text { Daily Positive Tests }(n)_{i}=\frac{\operatorname{CovID-19Daily~Cases~}(n)_{i}}{\operatorname{COVID-19Daily} T e s t s(n)_{i}} \quad \text { Equation } 8
$$

Where $\mathrm{n}$ is the number of cases/tests and $\mathrm{i}$ is the reported case date. For the comparative inferential statistical analysis conducted to understand the impact of the SARS-CoV-2 lineage clusters in Table 1 on the COVID-19 transmissibility during the three COVID-19 epidemic wave periods in South Africa the following analysis was conducted: 1) Descriptive Statistical Analysis on the COVID-19 Daily, Active Cases, Daily Positive Tests. 2) Paired Samples T-test at $95 \%$ Confidence Intervals in the COVID-19 Daily Positive Tests between the three COVID-19 epidemic wave periods using the IBM SPSS STATISTICS 27 Software with the following test pairings:

- COVID-19 Daily Positive Tests_1 with COVID-19 Daily Positive Tests_2.

- COVID-19 Daily Positive Tests_1 with COVID-19 Daily Positive Tests_3.

- COVID-19 Daily Positive Tests_2 with COVID-19 Daily Positive Tests_3.

\subsubsection{Comparative Analysis on the COVID-19 Severity in the South African COVID-19 Epidemic Wave Periods}

Disease severity is the measure of the relative proportions of symptoms and deaths due to the disease. SARSCOV-2 infections cause various symptoms such as coughing/sore throat, fever, myalgia or fatigue, respiratory symptoms, pneumonia. In moderate disease, pneumonia is reported and becomes severe in severe cases. In critical cases, it can cause acute respiratory distress syndrome (ARDS), dyspnoea, respiratory failure, sepsis, septic shock, acute thrombosis and multiple organ failure [58,69-71]. Patients with severe and critical COVID-19 are most likely to be hospitalised while those with moderate COVID-19 may present to an emergency unit or primary care/outpatient department [71]. Thus, the COVID-19 hospital admission status (indicative of care provided for COVID-19 inpatients), Admission and Deaths Age Profile (indicative of the severity by age), CFR (indicative of COVID-19 deaths in hospital) and the ECDR parameter (indicative of COVID-19 deaths outside of hospitals) can help one understand the severity of COVID-19. In this study, the COVID-19 severity was therefore measured through the magnitude of the mean and variance of the COVID-19 Hospital Admitted Cases, Admission Status, Admission Age Profile, Deaths Age Profile, CFR, DR and ECDR. Considering the linear positive correlation between the COVID-19 Active and Hospital Admitted Cases, for the comparative inferential analysis of COVID19 Hospital Admitted Cases between the COVID-19 epidemic wave periods a normalised parameter (COVID-19 Hospital to Active Cases) was developed based on Equation 9 to normalise the variance of active cases in hospital admitted cases.

$$
\text { COVID - } 19 \text { Hospital to Active Cases }(\%)=\frac{\overline{\text { COVID-19 Hospltal Admitted }(n)_{l}}}{\text { COVID-19 Active }(n)_{\iota}} \times 100 \quad \text { Equation } 9
$$

Where $\mathrm{n}$ is the number of patients and $\mathrm{i}$ is the reported case date. Considering the before mentioned variance as well as the positive correlation between the Number of Facilities Reporting to NICD DATCoV and COVID-19 Hospital Admitted Cases, for the comparative inferential analysis of COVID-19 Admission Status, Admission and Deaths Age Profile between the COVID-19 epidemic wave periods, normalised parameters were developed based on Equation 10, 11 and 12 to normalise the variance of active cases and Number of Facilities Reporting to the NICD DATCoV.

$$
\text { COVID - } 19 \text { Admission Status (\%) }=\frac{\overline{\text { COVID-19 Admission Status (n) })_{l}}}{\text { COVID-19 Hospital Admitted (n) })_{l}} \times 100
$$

\section{Equation 10}

Where the COVID-19 Admitted Status $(n)_{\mathrm{i}}$ is the number of COVID-19 patients in the General Ward, High Care, Intensive Care Unit, Isolation Ward, On Oxygen and Ventilators respectively.

$$
\text { COVID - } 19 \text { Admission Age Profile }(\%)=\frac{\overline{\text { COVID-19 Admission Age Profile }(\mathrm{n})_{l}}}{\text { COVID-19 Hospital Admitted (n) })_{\iota}} \times 100 \quad \text { Equation } 11
$$

Where the COVID-19 Admitted Age Profile (n) is the number of COVID-19 admitted patients in the ages of 0 to 9,10 to 19,20 to 29,30 to 39,40 to 49,50 to 59,60 to 69,70 to 79 and 80 to 89 years respectively.

COVID - 19 Hospital Death Age Profile $(\%)=\frac{\overline{\text { COVID-19 Hospital Death Age Profile (n) }}}{\text { COVID-19 Hospital Admitted }(\mathrm{n})_{\iota}} \times 100 \quad$ Equation 12

Where the COVID-19 Hospital Death Age Profile $(n)_{i}$ is the number of COVID-19 hospitalised patient deaths in the ages of 0 to 9,10 to 19,20 to 29,30 to 39,40 to 49,50 to 59,60 to 69,70 to 79 and 80 to 89 years respectively. 
medRxiv preprint doi: https://doi.org/10.1101/2021.10.22.21265316; this version posted October 25, 2021. The copyright holder for this preprint (which was not certified by peer review) is the author/funder, who has granted medRxiv a license to display the preprint in perpetuity.

It is made available under a CC-BY 4.0 International license.

Cumulative COVID-19 Age Death Risk Ratios or Case Fatality Age Risk Ratio (CFARR) in the three COVID19 epidemic wave periods for COVID-19 hospitalised patients deaths were then developed using Equation 13 referenced to the 0 to 9 age group.

$$
\text { CFARR(\%) }=\frac{\frac{\text { Mean COVID-19 Hospital Death Age Profile }(\mathrm{n})_{l}}{\text { Mean COVID-19 Hospital Death Age Profile }(0-9)_{l}}}{\text { Cquation } 13}
$$

For the comparative inferential statistical analysis conducted to understand the impact of the SARS-CoV-2 lineage clusters in Table 1 on the COVID-19 severity during the three COVID-19 epidemic wave periods in South Africa the following analysis was conducted: 1) Descriptive Statistical Analysis 2) Paired Samples T-test at $95 \%$ Confidence Intervals in the COVID-19 Hospital to Active Cases, Admission Status, Admission Age Profile, Hospital Death Age Profile (\%), CFR, DR and ECDR between the three COVID-19 epidemic wave periods using the IBM SPSS STATISTICS 27 Software. The test was conducted with the same test pairings regarding the COVID-19 epidemic wave periods as described in Section 2.3.1.

\section{Results and Discussions}

\subsection{Impact of SARS-CoV-2 Lineages on the COVID-19 Transmissibility in South Africa}

Table 8 shows the descriptive statistics for the COVID-19 active, daily cases and daily positive tests for the first, second and third COVID-19 epidemic wave periods in South Africa. Table 8 shows that the mean COVID-19 daily active cases in South Africa's first, second and third COVID-19 epidemic wave period were $51747 \pm 54618$, $66178 \pm 53878$ and $112236 \pm 60814$ respectively. The maximum COVID-19 daily active cases were 173590 , 239799 and 211052 respectively while the COVID-19 daily cases were $3211 \pm 3882,4336 \pm 5034$ and $8947 \pm 5$ 845 respectively. The mean COVID-19 active cases and daily cases in the third COVID-19 epidemic period in South Africa were observed to be higher than those of the first and second COVID-19 epidemic wave period.

Table 8: Statistical Sample Number (N), Minimum, Maximum, Mean, Standard Deviation (Std. Deviation) of COVID-19 Active Cases, Daily Cases and Positive Tests in the First, Second and Third COVID-19 Epidemic Wave Period in South Africa (Descriptive Statistics)

\begin{tabular}{|c|c|c|c|c|c|c|c|c|c|}
\hline \multicolumn{10}{|c|}{ Descriptive Statistics } \\
\hline & \multicolumn{2}{|c|}{ COVID-19 Active Cases } & \multicolumn{2}{c|}{ COVID-19 Daily Cases } & \multicolumn{3}{c|}{$\begin{array}{c}\text { COVID-19 Daily Positive } \\
\text { Tests }\end{array}$} \\
\hline $\begin{array}{c}\text { COVID-19 Epidemic } \\
\text { Wave Period }\end{array}$ & 1 & 2 & 3 & 1 & 2 & 3 & 1 & 2 & 3 \\
\hline N & 210 & 208 & 146 & 210 & 208 & 146 & 200 & 201 & 138 \\
\hline Minimum & 1 & 19809 & -76869 & 0 & 437 & 0 & 0.00 & 2.71 & 0.00 \\
\hline Maximum & 173590 & 239799 & 211052 & 13944 & 21980 & 26485 & 34.0 & 33.7 & 63.8 \\
\hline Mean & 51747 & 66178 & 112236 & 3211 & 4336 & 8947 & 11.6 & 11.5 & 17.8 \\
\hline Std. Deviation & 54618 & 53878 & 60814 & 3882 & 5034 & 5845 & 8.52 & 8.45 & 8.91 \\
\hline
\end{tabular}

The COVID-19 daily positive tests indicate the transmissibility of COVID-19 based on the detection rate of COVID-19 and account for covariance in the testing rate for statistical comparison between epidemic wave periods. The mean COVID-19 daily positive tests in South Africa's first, second and third COVID-19 epidemic wave period were $11.6 \pm 8.52 \%, 11.5 \pm 8.45 \%$ and $17.8 \pm 8.91 \%$ respectively. The mean COVID-19 daily positive tests in South Africa's first and second COVID-19 epidemic wave had a difference of $0.86 \%$. This difference was relatively small compared to the difference between the mean COVID-19 daily active and cases in the same periods. The relative difference of the mean COVID-19 daily positive tests, active and cases shows the need to account for the covariance of COVID-19 testing in COVID-19 daily active and cases to improve the accuracy of the respective parameters. The relatively small difference between the mean COVID-19 daily positive tests in South Africa's first and second COVID-19 epidemic wave suggests that the SARS-CoV-2 lineage cluster 1 (predominantly B.1.1.54, B.1.1.56 C.1 SARS-CoV-2 lineages) detected in the first COVID-19 epidemic wave period resulted in similar COVID-19 transmissibility in the South Africa population when compared with the SARS-CoV-2 lineage cluster 2 (predominantly Beta (B.1.351) SARS-CoV-2 VOC) detected in the second COVID-19 epidemic wave. The mean COVID-19 daily positive tests in South Africa's third COVID-19 epidemic wave were 53.9 and $54.8 \%$ more than those of the first and second COVID-19 epidemic wave period respectively. This result suggests that the SARS-CoV-2 lineage cluster 3 (predominantly Delta (B.1.617.2) SARS-CoV-2 VOC) 
medRxiv preprint doi: https://doi.org/10.1101/2021.10.22.21265316; this version posted October 25, 2021. The copyright holder for this preprint (which was not certified by peer review) is the author/funder, who has granted medRxiv a license to display the preprint in

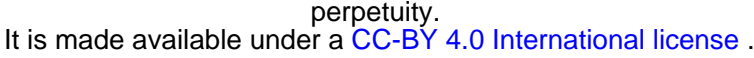

detected in the third COVID-19 epidemic wave resulted in higher COVID-19 transmissibility in the South African population than the SARS-CoV-2 lineage clusters 1 and 2. The difference between the mean COVID-19 daily positive tests in South Africa's first, second and third COVID-19 epidemic wave period can also be observed in Figure 2. A paired T-test of the COVID-19 daily positive tests between the first and second COVID-19 epidemic wave period showed no significant difference at $95 \%$ confidence interval between these COVID-19 epidemic periods with a p-value of 0.709 (shown in Table 9). While the paired T-test of the COVID-19 daily positive tests between the Pair 2 (first and third COVID-19 epidemic wave period) and Pair 3 (second and third COVID-19 epidemic wave period) showed significant difference at $95 \%$ confidence interval between the respective COVID19 epidemic periods with p-values of $1.82 \times 10^{-11}$ and $5.87 \times 10^{-05}$ respectively (shown in Table 9).

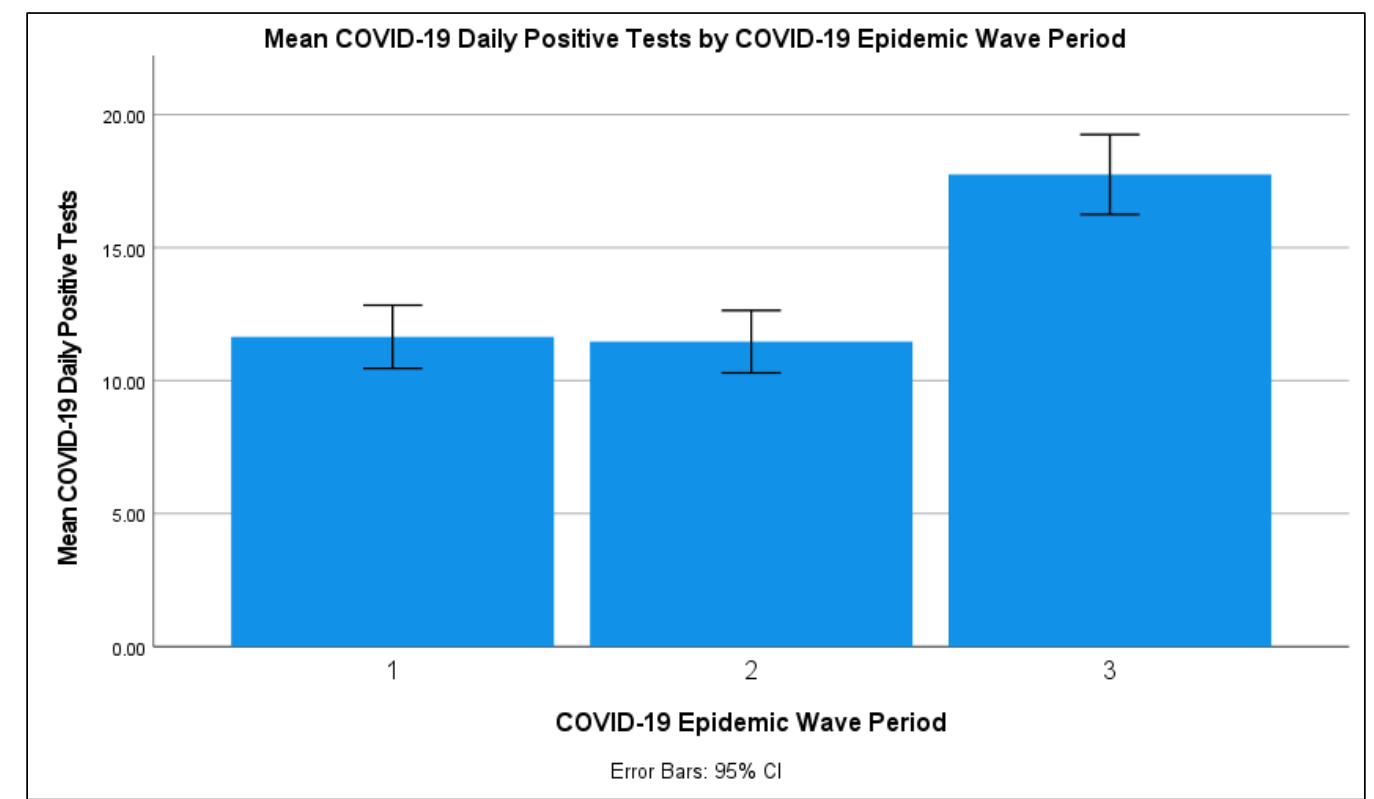

Figure 2: The mean COVID-19 Daily Positive Tests (with $95 \%$ Confidence Interval (CI) Error Bars) in the First, Second and Third COVID-19 Epidemic Wave Period in South Africa

Table 9:Mean Paired Differences, Standard Deviation (Std.) Paired Differences, Standard Error of Mean (Std. Error Mean), $95 \%$ Confidence Interval (CI) if the Upper and Lower Difference, $t$-value, degrees of freedom (df) and P-value (Sig. (2-tailed) for the COVID-19 Daily Positive Tests between Pair 1 ( $1^{\text {st }}$ and $2^{\text {nd }}$ COVID-19 Epidemic Wave Period), Pair $2\left(1^{\text {st }}\right.$ and $3^{\text {rd }}$ COVID-19 Epidemic Wave Period) and Pair 3 ( $2^{\text {nd }}$ and $3^{\text {rd }}$ COVID-19 Epidemic Wave Period) in South Africa. (Paired Samples T-Test)

\begin{tabular}{|c|c|c|c|}
\hline \multirow{2}{*}{} & Pair 1 & Pair 2 & Pair 3 \\
\cline { 2 - 4 } & $\begin{array}{c}\text { COVID-19 Daily Positive } \\
\text { Tests_1-COVID-19 Daily } \\
\text { Positive Tests_2 }\end{array}$ & $\begin{array}{c}\text { COVID-19 Daily Positive } \\
\text { Tests_1-COVID-19 Daily } \\
\text { Positive Tests_3 }\end{array}$ & $\begin{array}{c}\text { COVID-19 Daily Positive } \\
\text { Tests_2-COVID-19 Daily } \\
\text { Positive Tests_3 }\end{array}$ \\
\hline $\begin{array}{c}\text { Mean Paired } \\
\text { Differences }\end{array}$ & 0.36 & -8.68 & -2.54 \\
\hline $\begin{array}{c}\text { Std. Deviation } \\
\text { Paired } \\
\text { Differences }\end{array}$ & 13.2 & 13.3 & 6.99 \\
\hline $\begin{array}{c}\text { Std. Error Mean } \\
\text { 95\% Cl of the } \\
\text { Difference Lower }\end{array}$ & 0.96 & 1.18 & 0.61 \\
\hline $\begin{array}{c}\text { 95\% Cl of the } \\
\text { Difference Upper }\end{array}$ & -1.53 & -11.00 & -3.75 \\
\hline $\mathrm{t}$ & 2.25 & -6.35 & -1.33 \\
\hline df & 0.37 & -7.38 & -4.15 \\
\hline Sig. (2-tailed) & 190 & 127 & 130 \\
\hline
\end{tabular}


medRxiv preprint doi: https://doi.org/10.1101/2021.10.22.21265316; this version posted October 25, 2021. The copyright holder for this preprint (which was not certified by peer review) is the author/funder, who has granted medRxiv a license to display the preprint in perpetuity.

It is made available under a CC-BY 4.0 International license .

\subsection{Impact of SARS-CoV-2 Linages on the COVID-19 Severity in South Africa}

\subsubsection{Impact of SARS-CoV-2 Lineages on the COVID-19 Hospital Admissions}

The COVID-19 hospital to active cases indicates the severity of COVID-19 based on the relative amount of COVID-19 hospitalised cases to the active cases and accounts for the covariance of active cases in hospitalised cases. According to WHO, patients with severe and critical COVID-19 are most likely to be hospitalised while those with moderate COVID-19 may present to an emergency unit or primary care/outpatient department [71]. Table 10 shows the descriptive statistics for the COVID-19 hospital to active cases for the first, second and third COVID-19 epidemic wave periods in South Africa. Table 10 shows that the mean COVID-19 daily hospital to active cases in South Africa's first, second and third COVID-19 epidemic wave period were 6.8 $\pm 1.82 \%$, $14.5 \pm 4.68 \%$ and $10.6 \pm 2.81 \%$ respectively. The second COVID-19 epidemic wave period in South Africa had the highest COVID-19 hospital to active cases followed by the third COVID-19 epidemic wave period. The difference of the mean COVID-19 hospital to active cases between Pair 1 (COVID-19 epidemic wave period 1 and 2), Pair 2 (COVID-19 epidemic wave period 1 and 3), Pair 3 (COVID-19 epidemic wave period 2 and 3) was $113 \%, 55.8 \%$ and $36.8 \%$ respectively. The difference between the mean COVID-19 hospital to active cases in South Africa's first, second and third COVID-19 epidemic wave period can also be observed in Figure 3. Paired T-tests of the COVID-19 hospital to active cases between the Pair 1, Pair 2 and Pair 3 showed significant difference at $95 \%$ confidence interval between the respective COVID-19 epidemic periods with p-values of $4.25 \times 10^{-21}, 9.10 \times 10^{-44}$ and $3.90 \times 10^{-06}$ respectively (shown in Table 11 ).

Table 10: Statistical Sample Number (N), Minimum, Maximum, Mean, Standard Deviation (Std. Deviation) of COVID-19 Hospital to Active Cases in the First, Second and Third COVID-19 Epidemic Wave Period in South Africa (Descriptive Statistics)

\begin{tabular}{|c|c|c|c|}
\hline \multicolumn{3}{|c|}{ Descriptive Statistics } \\
\hline & \multicolumn{2}{|c|}{ COVID-19 Hospital To Active Cases (\%) } \\
\hline COVID-19 Epidemic Wave Period & 1 & 2 & 3 \\
\hline N & 126 & 187 & 145 \\
\hline Minimum & 4.0 & 6.5 & 7.2 \\
\hline Maximum & 12.7 & 23.5 & 18.3 \\
\hline Mean & 6.8 & 14.5 & 10.6 \\
\hline Std. Deviation & 1.82 & 4.68 & 2.81 \\
\hline
\end{tabular}

The results in Section 3.2.1 suggests that the SARS-CoV lineage cluster 2 (predominantly Beta (B.1.351) SARSCoV-2 VOC) resulted in an increase in severity of COVID-19 in the second COVID-19 epidemic wave period resulting in higher COVID-19 daily hospitalisation per active cases compared to the SARS-CoV-2 lineage clusters 1 and 3 in the first and third COVID-19 epidemic wave period in South Africa respectively. While the SARSCoV lineage cluster 3 (predominantly Delta (B.1.617.2) SARS-CoV-2 VOC) resulted in an increase in severity of COVID-19 resulting in higher daily COVID-19 hospitalisation per active cases compared to the SARS-CoV-2 lineage cluster 1 . 
medRxiv preprint doi: https://doi.org/10.1101/2021.10.22.21265316; this version posted October 25, 2021. The copyright holder for this preprint (which was not certified by peer review) is the author/funder, who has granted medRxiv a license to display the preprint in perpetuity.

It is made available under a CC-BY 4.0 International license .

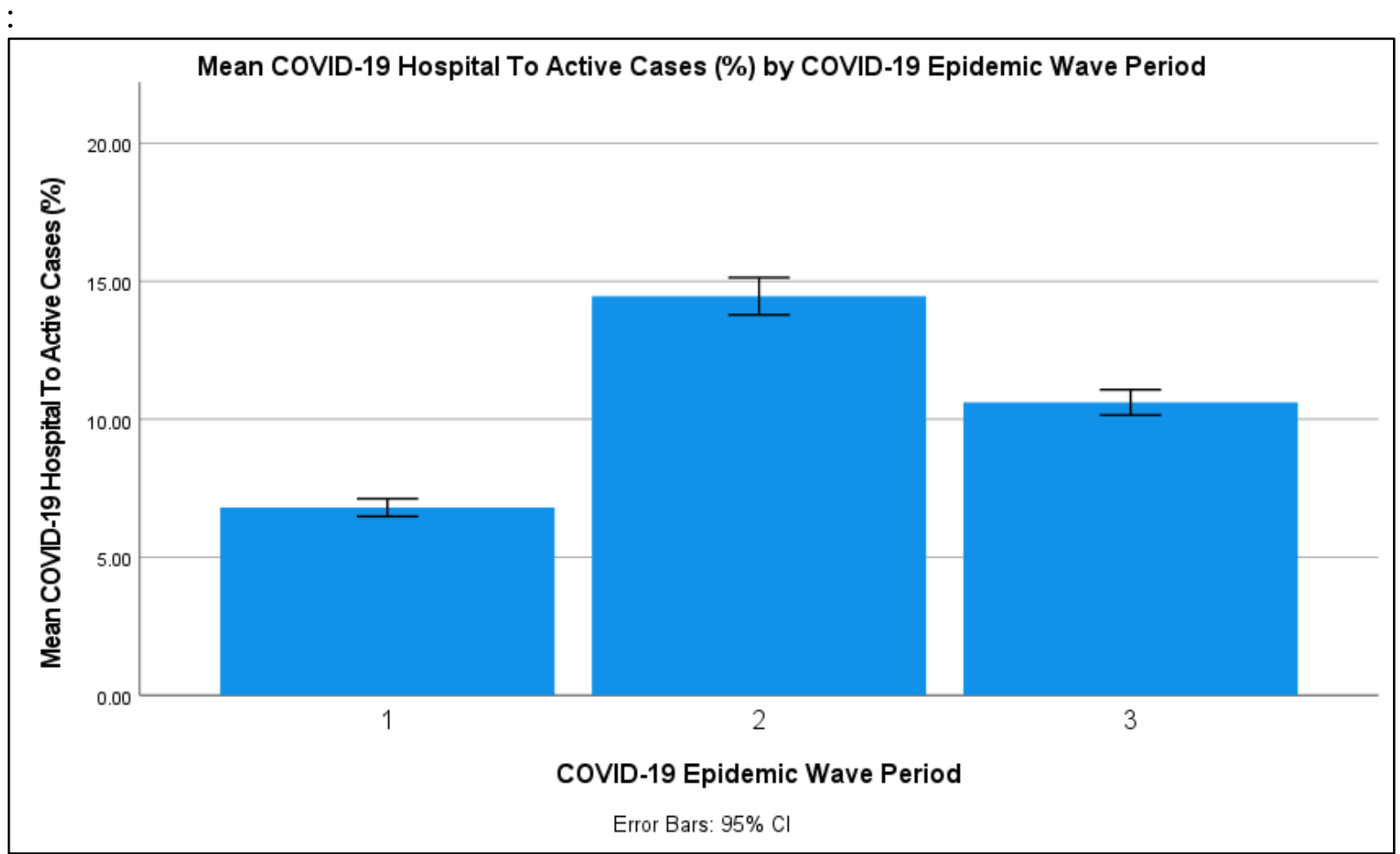

Figure 3: The mean COVID-19 Hospital to Active Cases (with $95 \%$ Confidence Interval (CI) Error Bars) in the First, Second and Third COVID-19 Epidemic Wave Period in South Africa

Table 11: Mean Paired Differences, Standard Deviation (Std.) Paired Differences, Standard Error of Mean (Std. Error Mean), $95 \%$ Confidence Interval (CI) if the Upper and Lower Difference, $t$-value, degrees of freedom ( $d f$ ) and P-value (Sig. (2-tailed) for the COVID-19 Hospital to Active Cases between Pair 1 ( $1^{\text {st }}$ and $2^{\text {nd }}$ COVID-19 Epidemic Wave Period), Pair 2 ( $1^{\text {st }}$ and $3^{\text {rd }}$ COVID-19 Epidemic Wave Period) and Pair 3 (2 $2^{\text {nd }}$ and $3^{\text {rd }}$ COVID-19 Epidemic Wave Period) in South Africa. (Paired Samples T-Test)

\begin{tabular}{|c|c|c|c|}
\hline \multicolumn{3}{|c|}{ Paired Samples Test } \\
\hline & \multicolumn{2}{|c|}{ COVID-19 Hospital To Active Cases(\%) } \\
\hline Test Pairing & Pair 1 & Pair 2 & Pair 3 \\
\hline Mean Paired Differences & -4.608 & -3.853 & 2.173 \\
\hline Std. Deviation Paired Differences & 4.000 & 1.998 & 5.005 \\
\hline Std. Error Mean & 0.389 & 0.179 & 0.449 \\
\hline $95 \%$ Cl of the Difference Lower & -5.379 & -4.207 & 3.283 \\
\hline 95\% Cl of the Difference Upper & -3.838 & -3.499 & 4.063 \\
\hline t & -11.86 & -21.56 & 123 \\
\hline Sig. (2-tailed) & 105 & 124 & $3.90 \mathrm{E}-06$ \\
\hline
\end{tabular}


medRxiv preprint doi: https://doi.org/10.1101/2021.10.22.21265316; this version posted October 25, 2021. The copyright holder for this preprint (which was not certified by peer review) is the author/funder, who has granted medRxiv a license to display the preprint in perpetuity.

It is made available under a CC-BY 4.0 International license.

\subsubsection{Impact of SARS-CoV-2 Lineages on the COVID-19 Hospital Admission Status}

Table 12 shows the descriptive statistics for the COVID-19 hospital admission status for the first, second and third COVID-19 epidemic wave periods in South Africa. Table 12 shows that the mean COVID-19 hospitalised cases in the first COVID-19 epidemic wave period in the general ward, high care, intensive care unit, on oxygen and ventilator were $72.8 \pm 2.6 \%, 7.9 \pm 1.0 \%, 16.7 \pm 2.2 \%, 16.8 \pm 5.8 \%$ and $7.8 \pm 1.8 \%$ respectively. The mean COVID19 hospitalised cases in the second COVID-19 epidemic wave period in the general ward, high care, intensive care unit, on oxygen and ventilator were $78.7 \pm 3.2 \%, 7.3 \pm 1.0 \%, 14.1 \pm 2.3 \%, 27.6 \pm 4.5 \%$ and $6.9 \pm 1.8 \%$ respectively. While the mean COVID-19 hospitalised cases in the third COVID-19 epidemic wave period in the general ward, high care, intensive care unit, on oxygen and ventilator were $76.0 \pm 2.5 \%, 7.6 \pm 1.1 \%, 16.3 \pm 1.7 \%$, $21.9 \pm 4.8 \%$ and $8.7 \pm 0.6 \%$ respectively. Figure 4 shows the COVID-19 hospital admission status profile in the first, second and third COVID-19 epidemic wave periods in South Africa.

Table 12: Statistical Sample Number (N), Minimum, Maximum, Mean, Standard Deviation (Std. Deviation) of COVID-19 Hospitalised Cases in the General Ward, High Care, Intensive Care Unit, On Oxygen, On Ventilator in the First, Second and Third COVID-19 Epidemic Wave Period in South Africa (Descriptive Statistics)

\begin{tabular}{|c|c|c|c|c|c|c|c|c|c|c|c|c|c|c|c|}
\hline \multicolumn{16}{|c|}{ Descriptive Statistics } \\
\hline & \multicolumn{3}{|c|}{$\begin{array}{c}\text { COVID-19 } \\
\text { Hospitalised } \\
\text { General Ward (\%) }\end{array}$} & \multicolumn{3}{|c|}{$\begin{array}{c}\text { COVID-19 } \\
\text { Hospitalised } \\
\text { High Care (\%) }\end{array}$} & \multicolumn{3}{|c|}{$\begin{array}{l}\text { COVID-19 } \\
\text { Hospitalised } \\
\text { Intensive Care } \\
\text { Unit (\%) }\end{array}$} & \multicolumn{3}{|c|}{$\begin{array}{c}\text { COVID-19 } \\
\text { Hospitalised } \\
\text { On Oxygen (\%) }\end{array}$} & \multicolumn{3}{|c|}{$\begin{array}{c}\text { COVID-19 } \\
\text { Hospitalised On } \\
\text { Ventilator (\%) }\end{array}$} \\
\hline $\begin{array}{c}\text { COVID-19 Epidemic Wave } \\
\text { Period }\end{array}$ & 1 & 2 & 3 & 1 & 2 & 3 & 1 & 2 & 3 & 1 & 2 & 3 & 1 & 2 & 3 \\
\hline $\mathrm{N}$ & 125 & 187 & 146 & 125 & 187 & 146 & 125 & 187 & 146 & 125 & 187 & 146 & 125 & 187 & 146 \\
\hline Minimum & 68.7 & 73.4 & 71.5 & 5.1 & 5.3 & 6.1 & 11.9 & 8.5 & 12.9 & 10.6 & 18.7 & 17.2 & 4.9 & 4.3 & 7.2 \\
\hline Maximum & 78.1 & 86.2 & 80.7 & 10.5 & 9.4 & 10.1 & 20.6 & 17.6 & 19.5 & 30.8 & 38.6 & 34.2 & 10.8 & 9.4 & 10.4 \\
\hline Mean & 72.8 & 78.7 & 76.0 & 7.9 & 7.3 & 7.6 & 16.7 & 14.1 & 16.3 & 16.8 & 27.6 & 21.9 & 7.8 & 6.9 & 8.7 \\
\hline Std. Deviation & 2.6 & 3.2 & 2.5 & 1.0 & 1.0 & 1.1 & 2.2 & 2.3 & 1.7 & 5.8 & 4.5 & 4.8 & 1.8 & 1.8 & 0.6 \\
\hline
\end{tabular}

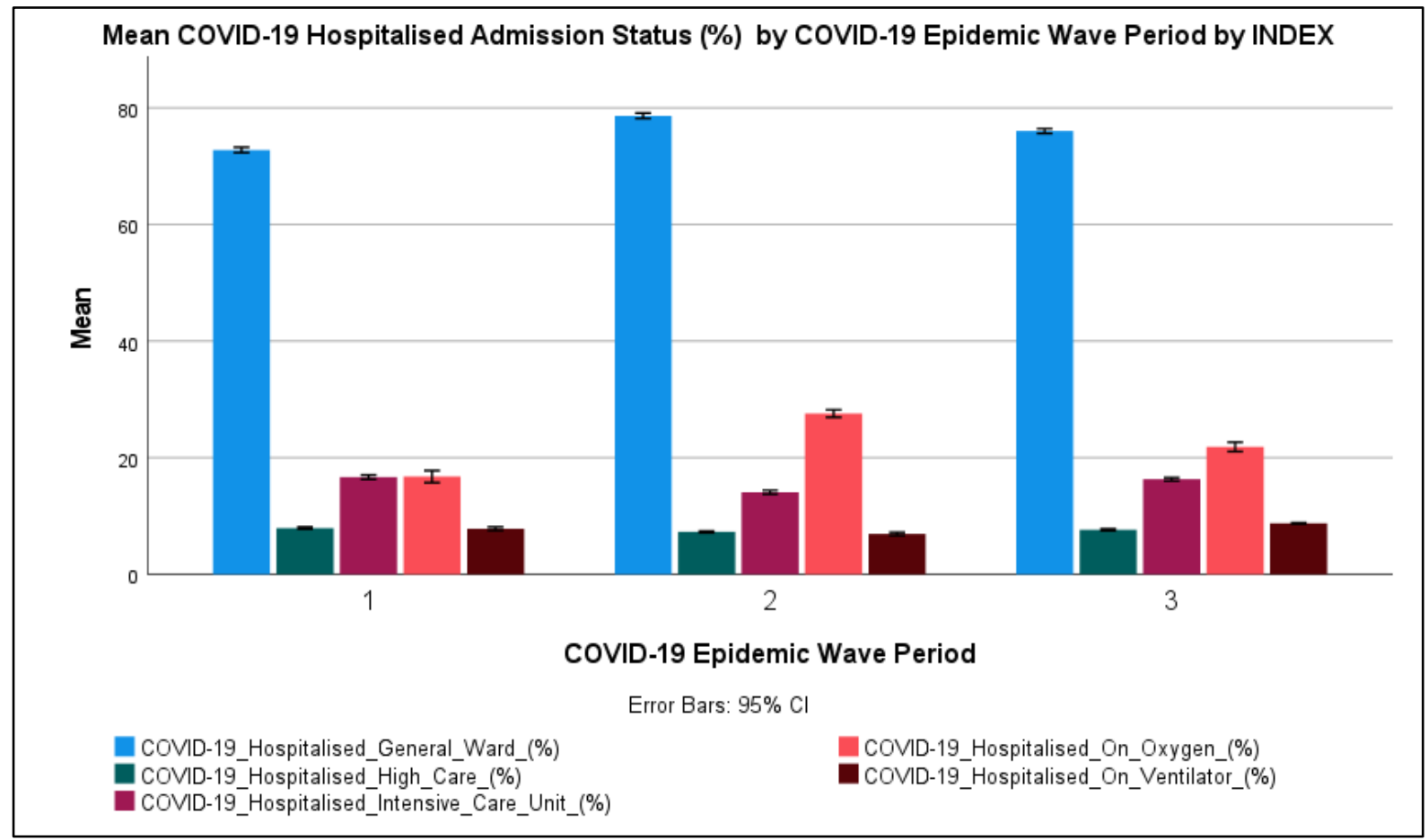

Figure 4: The mean COVID-19 Hospitalised Admission Status (with 95 \% Confidence Interval (CI) Error Bars) in the First, Second and Third COVID-19 Epidemic Wave Period in South Africa

Figure 4 shows that most COVID-19 hospitalised cases in South Africa were hospitalised in the general ward (72.8-78.7\%). Figure 4 also shows that the COVID-19 patients on Oxygen were the second-largest admission 
medRxiv preprint doi: https://doi.org/10.1101/2021.10.22.21265316; this version posted October 25, 2021. The copyright holder for this preprint (which was not certified by peer review) is the author/funder, who has granted medRxiv a license to display the preprint in perpetuity.

It is made available under a CC-BY 4.0 International license.

status (16.8-27.6\%) followed by the COVID-19 patients in the intensive care unit (14.1-16.7 \%). The COVID-19 patients on oxygen in the second and third COVID-19 epidemic wave period were higher than those observed in the first COVID-19 epidemic wave period with those in the second COVID-19 epidemic wave period being the highest. Paired T-tests of the mean COVID-19 hospital admission status in the Pair 1, Pair 2 and Pair 3 showed significant difference at $95 \%$ confidence interval between the respective COVID-19 epidemic periods with pvalues in the range of $2.86 \times 10^{-41}$ to 0.00219 respectively (shown in Table 13). Table 13 shows that the COVID19 patients admitted in the intensive care unit in the first and third COVID-19 epidemic wave period were not significantly different at a $95 \%$ confidence interval with a p-value of 0.514 .

The results in Section 3.2.2 suggest that the SARS-CoV-2 lineage clusters observed in the first, second and third COVID-19 epidemic wave periods in South Africa resulted in a similar distribution of the COVID-19 hospital admission status profile however the mean COVID-19 admission status was significantly different at $95 \%$ confidence interval. The results also show that the SARS-CoV-2 lineage cluster 1 (predominantly B.1.1.54, B.1.1.56 C.1 SARS-CoV-2 lineages) and SARS-CoV-2 lineage cluster 3 (predominantly Delta (B.1.617.2) SARSCoV-2 VOC) resulted in the same COVID-19 patients admitted in the intensive care unit relative to the total COVID-19 hospital admitted cases at $95 \%$ confidence interval. The SARS-CoV-2 lineage cluster 2 (predominantly Beta (B.1.351) SARS-CoV-2 VOC) was observed to have resulted in higher COVID-19 patients on oxygen than the SARS-CoV-2 lineage clusters 1 and 3.

Table 13: Mean Paired Differences, Standard Deviation (Std.) Paired Differences, Standard Error of Mean (Std. Error Mean), $95 \%$ Confidence Interval (CI) if the Upper and Lower Difference, $t$-value, degrees of freedom ( $d f$ ) and P-value (Sig. (2-tailed) for the COVID-19 Hospitalised Cases in the General Ward, High Care, Intensive Care Unit, On Oxygen, On Ventilator between Pair 1 ( $1^{\text {st }}$ and $2^{\text {nd }}$ COVID-19 Epidemic Wave Period), Pair 2 ( $1^{\text {st }}$ and $3^{\text {rd }}$ COVID-19 Epidemic Wave Period) and Pair 3 (2 $2^{\text {nd }}$ and $3^{\text {rd }}$ COVID-19 Epidemic Wave Period) in South Africa. (Paired Samples T-Test)

\begin{tabular}{|c|c|c|c|c|c|c|c|c|c|}
\hline \multicolumn{10}{|c|}{ Paired Samples Test } \\
\hline & \multicolumn{3}{|c|}{$\begin{array}{l}\text { COVID-19 Hospitalised } \\
\text { General Ward (\%) }\end{array}$} & \multicolumn{3}{|c|}{$\begin{array}{c}\text { COVID-19 Hospitalised High } \\
\text { Care (\%) }\end{array}$} & \multicolumn{3}{|c|}{$\begin{array}{l}\text { COVID-19 Hospitalised } \\
\text { Intensive Care Unit (\%) }\end{array}$} \\
\hline Test Pairing & Pair 1 & Pair 2 & Pair 3 & Pair 1 & Pair 2 & Pair 3 & Pair 1 & Pair 2 & Pair 3 \\
\hline Mean Paired Differences & -8.51 & -3.09 & 3.92 & 1.42 & 0.30 & -0.69 & 4.54 & 0.20 & -3.23 \\
\hline $\begin{array}{l}\text { Std. Deviation Paired } \\
\text { Differences } \\
\end{array}$ & 3.97 & 3.80 & 4.59 & 1.21 & 1.06 & 1.28 & 2.20 & 3.36 & 3.47 \\
\hline Std. Error Mean & 0.39 & 0.34 & 0.41 & 0.12 & 0.09 & 0.11 & 0.21 & 0.30 & 0.31 \\
\hline $95 \% \mathrm{Cl}$ of the Difference Lower & -9.28 & -3.76 & 3.11 & 1.19 & 0.11 & -0.92 & 4.12 & -0.40 & -3.84 \\
\hline $95 \% \mathrm{Cl}$ of the Difference Upper & -7.75 & -2.42 & 4.73 & 1.66 & 0.48 & -0.47 & 4.96 & 0.79 & -2.61 \\
\hline $\mathrm{t}$ & -22.092 & -9.088 & 9.541 & 12.156 & 3.129 & -6.047 & 21.246 & 0.654 & -10.405 \\
\hline df & 105 & 124 & 124 & 105 & 124 & 124 & 105 & 124 & 124 \\
\hline \multirow[t]{2}{*}{ Sig. (2-tailed) } & $2.86 \mathrm{E}-41$ & $2.01 \mathrm{E}-15$ & $1.63 \mathrm{E}-16$ & $9.41 \mathrm{E}-22$ & 0.00219 & 1.61E-08 & $8.20 \mathrm{E}-40$ & 0.514 & 1.31E-18 \\
\hline & \multicolumn{3}{|c|}{$\begin{array}{c}\text { COVID-19 Hospitalised On } \\
\text { Oxygen (\%) }\end{array}$} & \multicolumn{3}{|c|}{$\begin{array}{c}\text { COVID-19 Hospitalised On } \\
\text { Ventilator (\%) }\end{array}$} & & & \\
\hline Mean Paired Differences & -12.05 & -5.70 & 7.31 & 2.42 & -0.94 & -2.56 & & & \\
\hline $\begin{array}{l}\text { Std. Deviation Paired } \\
\text { Differences }\end{array}$ & 6.02 & 8.90 & 7.65 & 2.49 & 2.08 & 2.06 & & & \\
\hline Std. Error Mean & 0.59 & 0.80 & 0.68 & 0.24 & 0.19 & 0.18 & & & \\
\hline $95 \% \mathrm{Cl}$ of the Difference Lower & -13.22 & -7.28 & 5.95 & 1.94 & -1.31 & -2.93 & & & \\
\hline $95 \% \mathrm{Cl}$ of the Difference Upper & -10.89 & -4.13 & 8.66 & 2.90 & -0.57 & -2.20 & & & \\
\hline $\mathrm{t}$ & -20.600 & -7.167 & 10.678 & 10.023 & -5.029 & -13.939 & & & \\
\hline df & 105 & 124 & 124 & 105 & 124 & 124 & & & \\
\hline Sig. (2-tailed) & 1.13E-38 & $6.02 \mathrm{E}-11$ & 2.84E-19 & $5.45 \mathrm{E}-17$ & 1.68E-06 & 3.77E-27 & & & \\
\hline
\end{tabular}


medRxiv preprint doi: https://doi.org/10.1101/2021.10.22.21265316; this version posted October 25, 2021. The copyright holder for this preprint (which was not certified by peer review) is the author/funder, who has granted medRxiv a license to display the preprint in perpetuity.

It is made available under a CC-BY 4.0 International license.

\subsubsection{Impact of SARS-CoV-2 Lineages on the COVID-19 Hospital Admission Age Profile}

Table 14 shows the descriptive statistics for the COVID-19 hospital admission age profile for the first, second and third COVID-19 epidemic wave periods in South Africa. Table 14Table 12 shows that the mean COVID-19 hospitalised cases in the first COVID-19 epidemic wave period in the ages of 0 to 9,10 to 19,20 to 29,30 to 39 , 40 to 49,50 to 59,60 to 69,70 to 79 and 80 to 89 years were $2.4 \pm 0.6 \%, 1.8 \pm 0.3 \%, 7.5 \pm 2.6 \%, 17.4 \pm 4.4 \%$, $19.5 \pm 4.9 \%, 24.0 \pm 6.1 \%, 16.2 \pm 5.4 \%, 7.1 \pm 4.4 \%$ and $5.6 \pm 1.6 \%$ respectively. The mean COVID-19 hospitalised cases in the second COVID-19 epidemic wave period in the ages of 0 to 9,10 to 19,20 to 29,30 to 39,40 to 49 , 50 to 59,60 to 69,70 to 79 and 80 to 89 years were $1.9 \pm 0.3 \%, 4.4 \pm 2.2 \%, 7.2 \pm 2.0 \%, 14.2 \pm 1.7 \%, 17.0 \pm 1.2 \%$, $19.6 \pm 4.8 \%, 18.2 \pm 1.8 \%, 9.8 \pm 3.2 \%$ and $5.0 \pm 0.6 \%$ respectively. While, the mean COVID-19 hospitalised cases in the third COVID-19 epidemic wave period in the ages of 0 to 9,10 to 19,20 to 29,30 to 39,40 to 49,50 to 59 , 60 to 69,70 to 79 and 80 to 89 years were $2.3 \pm 0.5 \%, 2.3 \pm 0.5 \%, 6.4 \pm 7.4 \%, 9.4 \pm 3.8 \%, 13.5 \pm 3.3 \%, 12.9 \pm 9.1$ $\%, 15.5 \pm 7.4 \%, 12.8 \pm 3.2 \%$ and $6.5 \pm 1.7 \%$ respectively. Figure 5 shows the COVID-19 hospital admission age profile in the first, second and third COVID-19 epidemic wave periods in South Africa.

Table 14: Statistical Sample Number (N), Minimum, Maximum, Mean, Standard Deviation (Std. Deviation) of COVID-19 Hospitalised Cases in the Ages of 0 to 9, 10 to 19, 20 to 29, 30 to 39, 40 to 49, 50 to 59, 60 to 69, 70 to 79, 80 to 89 years in the First, Second and Third COVID-19 Epidemic Wave Period in South Africa (Descriptive Statistics)

\begin{tabular}{|c|c|c|c|c|c|c|c|c|c|}
\hline \multicolumn{10}{|c|}{ Descriptive Statistics } \\
\hline & \multicolumn{3}{|c|}{$\begin{array}{l}\text { COVID-19 Hospitalised } \\
\text { Admitted Age 0-9 (\%) }\end{array}$} & \multicolumn{3}{|c|}{$\begin{array}{l}\text { COVID-19 Hospitalised } \\
\text { Admitted Age 10-19 (\%) }\end{array}$} & \multicolumn{3}{|c|}{$\begin{array}{l}\text { COVID-19 Hospitalised } \\
\text { Admitted Age 20-29 (\%) }\end{array}$} \\
\hline $\begin{array}{c}\text { COVID-19 } \\
\text { Epidemic Wave } \\
\text { Period }\end{array}$ & 1 & 2 & 3 & 1 & 2 & 3 & 1 & 2 & 3 \\
\hline $\mathrm{N}$ & 110 & 180 & 143 & 108 & 179 & 143 & 126 & 180 & 143 \\
\hline Minimum & 1.7 & 1.4 & 0.2 & 1.2 & 1.2 & 0.2 & 0.4 & -2.6 & 1.2 \\
\hline Maximum & 4.0 & 3.0 & 3.7 & 2.9 & 9.9 & 3.9 & 14.6 & 13.5 & 92.8 \\
\hline Mean & 2.4 & 1.9 & 2.3 & 1.8 & 4.4 & 2.3 & 7.5 & 7.2 & 6.4 \\
\hline \multirow[t]{2}{*}{ Std. Deviation } & 0.6 & 0.3 & 0.5 & 0.3 & 2.2 & 0.5 & 2.6 & 2.0 & 7.4 \\
\hline & \multicolumn{3}{|c|}{$\begin{array}{l}\text { COVID-19 Hospitalised } \\
\text { Admitted Age 30-39 (\%) }\end{array}$} & \multicolumn{3}{|c|}{$\begin{array}{l}\text { COVID-19 Hospitalised } \\
\text { Admitted Age 40-49 (\%) }\end{array}$} & \multicolumn{3}{|c|}{$\begin{array}{l}\text { COVID-19 Hospitalised } \\
\text { Admitted Age 50-59 (\%) }\end{array}$} \\
\hline $\mathrm{N}$ & 126 & 180 & 143 & 75 & 180 & 143 & 126 & 180 & 143 \\
\hline Minimum & 2.4 & 1.9 & 0.9 & 2.2 & 2.4 & 1.9 & 3.1 & 2.2 & 1.6 \\
\hline Maximum & 29.8 & 22.4 & 12.8 & 27.4 & 18.6 & 15.6 & 38.4 & 24.2 & 22.9 \\
\hline Mean & 17.4 & 14.2 & 9.4 & 19.5 & 17.0 & 13.5 & 24.0 & 19.6 & 12.9 \\
\hline \multirow[t]{2}{*}{ Std. Deviation } & 4.4 & 1.7 & 3.8 & 4.9 & 1.2 & 3.3 & 6.1 & 4.8 & 9.1 \\
\hline & \multicolumn{3}{|c|}{$\begin{array}{l}\text { COVID-19 Hospitalised } \\
\text { Admitted Age 60-69 (\%) }\end{array}$} & \multicolumn{3}{|c|}{$\begin{array}{l}\text { COVID-19 Hospitalised } \\
\text { Admitted Age } 70-79(\%)\end{array}$} & \multicolumn{3}{|c|}{$\begin{array}{l}\text { COVID-19 Hospitalised } \\
\text { Admitted Age 80-89 (\%) }\end{array}$} \\
\hline $\mathrm{N}$ & 125 & 180 & 143 & 126 & 180 & 142 & 125 & 180 & 143 \\
\hline Minimum & 1.5 & 12.7 & 1.6 & 1.3 & 1.1 & 1.8 & 0.9 & 2.8 & 0.5 \\
\hline Maximum & 24.3 & 21.5 & 22.3 & 16.3 & 13.0 & 15.0 & 9.4 & 6.4 & 7.9 \\
\hline Mean & 16.2 & 18.2 & 15.5 & 7.1 & 9.8 & 12.8 & 5.6 & 5.0 & 6.5 \\
\hline Std. Deviation & 5.4 & 1.8 & 7.4 & 4.4 & 3.2 & 3.2 & 1.6 & 0.6 & 1.7 \\
\hline
\end{tabular}

Figure 5 shows that most COVID-19 hospitalised cases in South Africa's first, second and third COVID-19 epidemic wave period were in the ages of 50 to59 (19.6\%), 50 to $59(24.0 \%)$ and 60 to $69(15.5 \%)$ years respectively. COVID-19 patients in the age groups of 40 to 49 were the second-largest admitted age groups in the first and third COVID-19 epidemic wave period (14.1-16.7 \%) while for the second COVID-19 epidemic wave period it was the age group of 60 to 69 years (18.2\%). COVID-19 admitted patients in the age groups of 0 to 19 years were relatively low (1.8 to $4.4 \%$ ) and highest in the second COVID-19 epidemic wave period. The incidence of COVID-19 in children has been reported to be low around the world particularly severe and critical COVID19 requiring hospitalisation [8]. Figure 5 shows that the COVID-19 hospital admitted age profile for the first and 
medRxiv preprint doi: https://doi.org/10.1101/2021.10.22.21265316; this version posted October 25, 2021. The copyright holder for this preprint (which was not certified by peer review) is the author/funder, who has granted medRxiv a license to display the preprint in

perpetuity.
It is made available under a CC-BY 4.0 International license.

second COVID-19 epidemic wave period was relative normally distributed, while the distribution in the third COVID epidemic wave period was left-skewed with increased incidence in the age groups over 70 years.

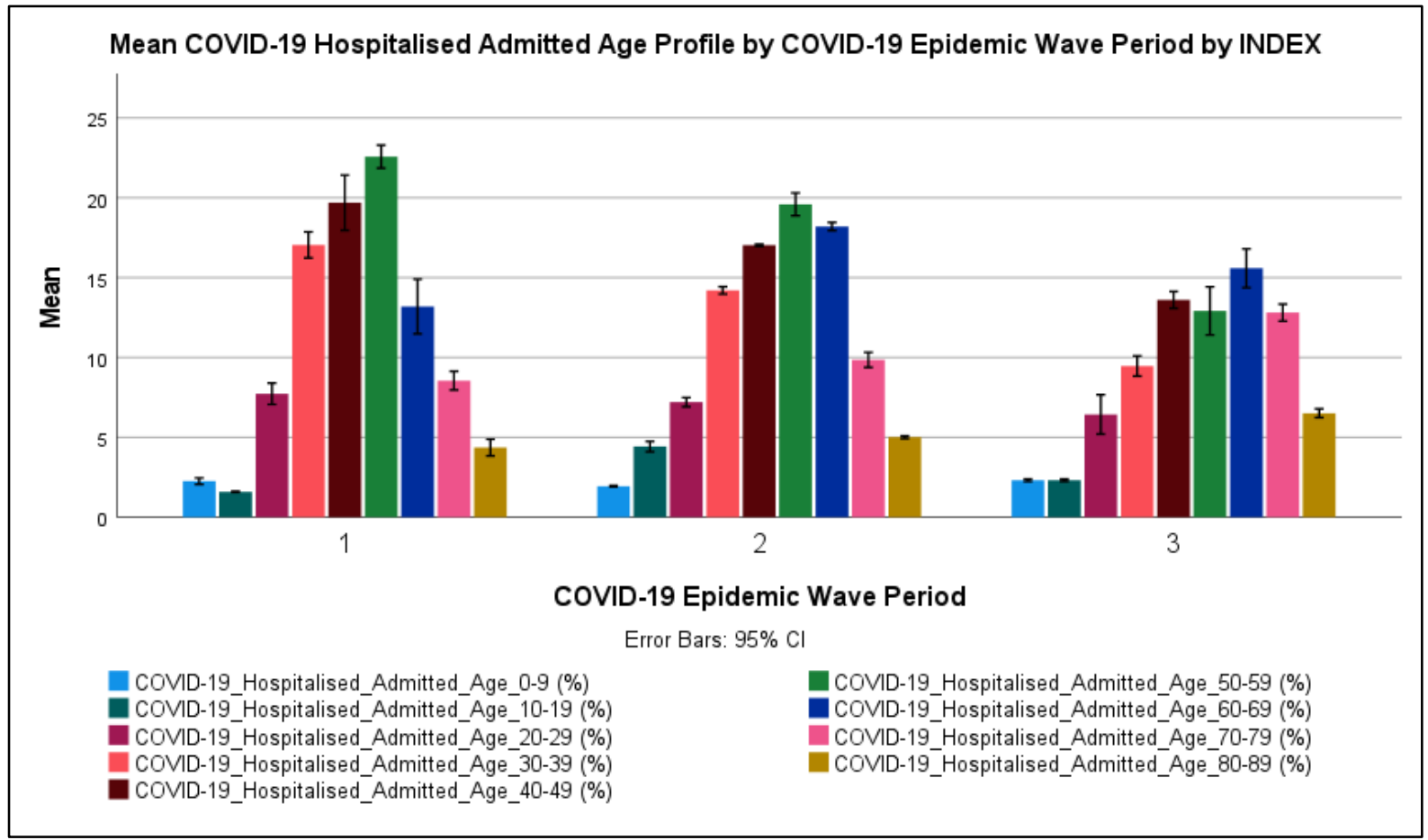

Figure 5: The mean COVID-19 Hospitalised Admission Age Profile (with $95 \%$ Confidence Interval (CI) Error Bars) in the First, Second and Third COVID-19 Epidemic Wave Period in South Africa

In general, paired T-tests of the COVID-19 hospital admission age profile in Pair 1, Pair 2 and Pair 3 showed significant differences at $95 \%$ confidence interval between the respective COVID-19 epidemic periods with pvalues in the range of $7.66 \times 10^{-44}$ to 0.040 respectively (shown in Table 15 ). However, Table 15 also shows that the COVID-19 patients admitted in age group 0 to 9 years in first and third COVID-19 epidemic wave periods, age group 20 to 29 years in second and third COVID-19 epidemic wave periods, age group 60 to 69 years in first and, second and third COVID-19 epidemic wave periods, age group 70 to 79 years in first and second COVID19 epidemic wave periods were significant similar at 95 confidence interval with p-values of 0.111 to 0.530 .

The results in Section 3.2.3 suggest that the SARS-CoV-2 lineage clusters observed in the first, second and third COVID-19 epidemic wave periods in South Africa resulted in different distributions of the COVID-19 hospital admission age profile. The results also show that the SARS-CoV-2 lineage cluster 3 (predominantly Delta (B.1.617.2) resulted in an increased incidence in COVID-19 patients in the age groups over 70 years compared to the SARS SARS-CoV-2 lineage cluster 1 (predominantly B.1.1.54, B.1.1.56 C.1 SARS-CoV-2 lineages) and the SARS-CoV-2 lineage cluster 2 (predominantly Beta (B.1.351) SARS-CoV-2 VOC). 
medRxiv preprint doi: https://doi.org/10.1101/2021.10.22.21265316; this version posted October 25, 2021. The copyright holder for this preprint (which was not certified by peer review) is the author/funder, who has granted medRxiv a license to display the preprint in perpetuity.

It is made available under a CC-BY 4.0 International license.

Table 15: Mean Paired Differences, Standard Deviation (Std.) Paired Differences, Standard Error of Mean (Std. Error Mean), $95 \%$ Confidence Interval (CI) if the Upper and Lower Difference, $t$-value, degrees of freedom ( $d f$ ) and P-value (Sig. (2-tailed) for the COVID-19 Hospitalised Cases in the Ages of 0 to 9, 10 to 19, 20 to 29, 30 to 39, 40 to 49, 50 to 59, 60 to 69, 70 to 79, 80 to 89 years between Pair 1 ( $1^{\text {st }}$ and $2^{\text {nd }}$ COVID-19 Epidemic Wave Period), Pair 2 ( $1^{\text {st }}$ and $3^{\text {rd }}$ COVID-19 Epidemic Wave Period) and Pair 3 (2nd and $3^{\text {rd }}$ COVID-19 Epidemic Wave Period) in South Africa. (Paired Samples T-Test)

\begin{tabular}{|c|c|c|c|c|c|c|c|c|c|}
\hline \multirow[b]{2}{*}{ Test Pairing } & \multicolumn{3}{|c|}{$\begin{array}{l}\text { COVID-19 Hospitalised } \\
\text { Admitted Age 0-9 (\%) }\end{array}$} & \multicolumn{3}{|c|}{$\begin{array}{l}\text { COVID-19 Hospitalised } \\
\text { Admitted Age 10-19 (\%) }\end{array}$} & \multicolumn{3}{|c|}{$\begin{array}{l}\text { COVID-19 Hospitalised } \\
\text { Admitted Age 20-29 (\%) }\end{array}$} \\
\hline & Pair 1 & Pair 2 & Pair 3 & Pair 1 & Pair 2 & Pair 3 & Pair 1 & Pair 2 & Pair 3 \\
\hline Mean Paired Differences & 0.19 & -0.05 & -0.38 & -4.25 & -0.65 & 2.98 & -0.66 & 1.34 & 1.25 \\
\hline Std. Deviation Paired Differences & 0.69 & 0.74 & 0.56 & 2.22 & 0.38 & 2.27 & 3.15 & 2.58 & 8.36 \\
\hline Std. Error Mean & 0.08 & 0.07 & 0.05 & 0.25 & 0.04 & 0.21 & 0.32 & 0.23 & 0.78 \\
\hline $95 \% \mathrm{Cl}$ of the Difference Lower & 0.04 & -0.19 & -0.49 & -4.74 & -0.72 & 2.56 & -1.29 & 0.88 & -0.29 \\
\hline 95\% Cl of the Difference Upper & 0.34 & 0.10 & -0.28 & -3.76 & -0.57 & 3.40 & -0.03 & 1.80 & 2.80 \\
\hline $\mathrm{t}$ & 2.482 & -0.647 & -7.319 & -17.192 & -17.445 & 14.066 & -2.083 & 5.753 & 1.605 \\
\hline df & 82 & 107 & 114 & 80 & 104 & 114 & 98 & 122 & 114 \\
\hline \multirow[t]{2}{*}{ Sig. (2-tailed) } & 0.015 & 0.519 & $3.78 \mathrm{E}-11$ & $1.37 \mathrm{E}-28$ & $1.17 \mathrm{E}-32$ & $1.14 \mathrm{E}-26$ & 0.040 & $6.65 \mathrm{E}-08$ & 0.111 \\
\hline & \multicolumn{3}{|c|}{$\begin{array}{l}\text { COVID-19 Hospitalised } \\
\text { Admitted Age 40-49 (\%) }\end{array}$} & \multicolumn{3}{|c|}{$\begin{array}{l}\text { COVID-19 Hospitalised } \\
\text { Admitted Age 50-59 (\%) }\end{array}$} & \multicolumn{3}{|c|}{$\begin{array}{l}\text { COVID-19 Hospitalised } \\
\text { Admitted Age 60-69 (\%) }\end{array}$} \\
\hline Mean Paired Differences & 1.49 & 7.39 & 5.86 & 2.06 & 5.17 & 3.91 & 6.80 & 10.69 & 4.04 \\
\hline Std. Deviation Paired Differences & 4.31 & 4.99 & 4.65 & 0.37 & 4.89 & 3.45 & 8.95 & 11.62 & 11.04 \\
\hline Std. Error Mean & 0.43 & 0.45 & 0.43 & 0.05 & 0.57 & 0.32 & 0.90 & 1.05 & 1.03 \\
\hline 95\% Cl of the Difference Lower & 0.63 & 6.50 & 5.00 & 1.96 & 4.03 & 3.27 & 5.01 & 8.62 & 2.00 \\
\hline $95 \% \mathrm{Cl}$ of the Difference Upper & 2.35 & 8.28 & 6.72 & 2.16 & 6.31 & 4.55 & 8.58 & 12.77 & 6.08 \\
\hline $\mathrm{t}$ & 3.438 & 16.422 & 13.512 & 41.673 & 9.029 & 12.142 & 7.555 & 10.210 & 3.928 \\
\hline df & 98 & 122 & 114 & 56 & 72 & 114 & 98 & 122 & 114 \\
\hline \multirow[t]{2}{*}{ Sig. (2-tailed) } & 0.001 & 1.09E-32 & 2.03E-25 & $7.66 \mathrm{E}-44$ & $1.84 \mathrm{E}-13$ & 2.81E-22 & 2.23E-11 & $4.59 \mathrm{E}-18$ & 1.47E-04 \\
\hline & \multicolumn{3}{|c|}{$\begin{array}{l}\text { COVID-19 Hospitalised } \\
\text { Admitted Age 60-69 (\%) }\end{array}$} & \multicolumn{3}{|c|}{$\begin{array}{l}\text { COVID-19 Hospitalised } \\
\text { Admitted Age 70-79 (\%) }\end{array}$} & \multicolumn{3}{|c|}{$\begin{array}{l}\text { COVID-19 Hospitalised } \\
\text { Admitted Age 80-89 (\%) }\end{array}$} \\
\hline Mean Paired Differences & 0.45 & -0.49 & 3.26 & -0.55 & -6.80 & -3.77 & 1.47 & -1.43 & -1.71 \\
\hline Std. Deviation Paired Differences & 3.60 & 8.53 & 7.67 & 7.04 & 4.21 & 5.76 & 0.81 & 1.64 & 2.18 \\
\hline Std. Error Mean & 0.36 & 0.77 & 0.72 & 0.71 & 0.38 & 0.54 & 0.08 & 0.15 & 0.20 \\
\hline 95\% Cl of the Difference Lower & -0.27 & -2.02 & 1.84 & -1.95 & -7.55 & -4.83 & 1.31 & -1.73 & -2.12 \\
\hline $95 \% \mathrm{Cl}$ of the Difference Upper & 1.18 & 1.04 & 4.67 & 0.86 & -6.05 & -2.70 & 1.63 & -1.14 & -1.31 \\
\hline $\mathrm{t}$ & 1.244 & -0.629 & 4.552 & -0.774 & -17.908 & -6.979 & 17.994 & -9.623 & -8.413 \\
\hline df & 97 & 121 & 114 & 98 & 122 & 113 & 97 & 121 & 114 \\
\hline Sig. (2-tailed) & 0.216 & 0.530 & $1.34 \mathrm{E}-05$ & 0.441 & $6.05 E-36$ & $2.15 \mathrm{E}-10$ & $1.14 \mathrm{E}-32$ & $1.27 \mathrm{E}-16$ & $1.32 \mathrm{E}-13$ \\
\hline
\end{tabular}

\subsubsection{Impact of SARS-CoV-2 Lineages on the COVID-19 Hospital Deaths Age Profile}

Table 16 shows the descriptive statistics for the COVID-19 hospital death age profile for the first, second and third COVID-19 epidemic wave periods in South Africa. Table 16Table 12 shows that the mean COVID-19 hospitalised deaths in the first COVID-19 epidemic wave period in the ages of 0 to 9,10 to 19,20 to 29,30 to 39 , 40 to 49,50 to 59,60 to 69,70 to 79 and 80 to 89 years were $0.194 \pm 0.111 \%, 0.254 \pm 0.089 \%, 1.34 \pm 0.312 \%$, $5.20 \pm 0.62 \%, 11.7 \pm 0.9 \%, 14.8 \pm 12.0 \%, 25.8 \pm 2.74 \%, 18.1 \pm 2.18 \%$ and $11.7 \pm 2.28 \%$ respectively. The mean COVID-19 hospitalised deaths in the second COVID-19 epidemic wave period in the ages of 0 to 9,10 to 19,20 to 29,30 to 39,40 to 49,50 to 59,60 to 69,70 to 79 and 80 to 89 years were $0.250 \pm 0.095 \%, 0.398 \pm 0.132 \%$, $1.97 \pm 0.500 \%, 5.67 \pm 0.5 \%, 10.8 \pm 0.3 \%, 41.2 \pm 20.7 \%, 28.5 \pm 4.27 \%, 20.0 \pm 3.12 \%$ and $10.6 \pm 1.94 \%$ respectively. While, the mean COVID-19 hospitalised deaths in the third COVID-19 epidemic wave period in the ages of 0 to 9,10 to 19,20 to 29,30 to 39,40 to 49,50 to 59,60 to 69,70 to 79 and 80 to 89 years were $0.944 \pm 6.18 \%$, $0.217 \pm 0.074 \%, 0.990 \pm 0.297 \%, 4.60 \pm 2.0 \%, 7.8 \pm 2.0 \%, 18.1 \pm 4.0 \%, 25.6 \pm 6.93 \%, 21.3 \pm 5.43 \%$ and $13.4 \pm 3.24$ $\%$ respectively. Figure 5 Figure 6 shows the COVID-19 hospital death age profile in the first, second and third COVID-19 epidemic wave periods in South Africa. 
medRxiv preprint doi: https://doi.org/10.1101/2021.10.22.21265316; this version posted October 25, 2021. The copyright holder for this preprint (which was not certified by peer review) is the author/funder, who has granted medRxiv a license to display the preprint in

perpetuity.
It is made available under a CC-BY 4.0 International license .

Table 16: Statistical Sample Number (N), Minimum, Maximum, Mean, Standard Deviation (Std. Deviation) of COVID-19 Hospitalised Deaths in the Ages of 0 to 9, 10 to 19, 20 to 29, 30 to 39, 40 to 49, 50 to 59, 60 to 69, 70 to 79, 80 to 89 years in the First, Second and Third COVID-19 Epidemic Wave Period in South Africa (Descriptive Statistics)

\begin{tabular}{|c|c|c|c|c|c|c|c|c|c|}
\hline \multicolumn{10}{|c|}{ Descriptive Statistics } \\
\hline & \multicolumn{3}{|c|}{$\begin{array}{l}\text { COVID-19 Hospital } \\
\text { Deaths Age 0-9 (\%) }\end{array}$} & \multicolumn{3}{|c|}{$\begin{array}{l}\text { COVID-19 Hospital } \\
\text { Deaths Age 10-19 (\%) }\end{array}$} & \multicolumn{3}{|c|}{$\begin{array}{l}\text { COVID-19 Hospital } \\
\text { Deaths Age 20-29 (\%) }\end{array}$} \\
\hline $\begin{array}{l}\text { COVID-19 Epidemic } \\
\text { Wave Period }\end{array}$ & 1 & 2 & 3 & 1 & 2 & 3 & 1 & 2 & 3 \\
\hline $\mathrm{N}$ & 126 & 187 & 146 & 126 & 187 & 146 & 126 & 187 & 146 \\
\hline Minimum & 0.00 & 0.00 & 0.00 & 0.00 & 0.00 & 0.00 & 0.00 & 0.00 & 0.00 \\
\hline Maximum & 0.64 & 0.44 & 75.00 & 0.34 & 1.25 & 0.31 & 2.26 & 3.81 & 1.61 \\
\hline Mean & 0.194 & 0.250 & 0.944 & 0.254 & 0.398 & 0.217 & 1.341 & 1.965 & 0.990 \\
\hline \multirow[t]{2}{*}{ Std. Deviation } & 0.111 & 0.095 & 6.176 & 0.089 & 0.132 & 0.074 & 0.312 & 0.500 & 0.297 \\
\hline & \multicolumn{3}{|c|}{$\begin{array}{l}\text { COVID-19 Hospital } \\
\text { Deaths Age 30-39 (\%) }\end{array}$} & \multicolumn{3}{|c|}{$\begin{array}{l}\text { COVID-19 Hospital } \\
\text { Deaths Age } 40-49(\%)\end{array}$} & \multicolumn{3}{|c|}{$\begin{array}{l}\text { COVID-19 Hospital } \\
\text { Deaths Age 50-59 (\%) }\end{array}$} \\
\hline $\mathrm{N}$ & 126 & 187 & 146 & 126 & 187 & 146 & 125 & 162 & 146 \\
\hline Minimum & 0.73 & 5.10 & 1.96 & 5.13 & 9.81 & 0.00 & 0.00 & 0.00 & 8.39 \\
\hline Maximum & 6.33 & 7.27 & 25.00 & 13.32 & 11.63 & 10.38 & 27.91 & 98.20 & 25.00 \\
\hline Mean & 5.20 & 5.67 & 4.60 & 11.7 & 10.8 & 7.8 & 14.8 & 41.2 & 18.1 \\
\hline \multirow[t]{2}{*}{ Std. Deviation } & 0.62 & 0.5 & 2.0 & 0.9 & 0.3 & 2.0 & 12.0 & 20.7 & 4.0 \\
\hline & \multicolumn{3}{|c|}{$\begin{array}{l}\text { COVID-19 Hospital } \\
\text { Deaths Age 60-69 (\%) }\end{array}$} & \multicolumn{3}{|c|}{$\begin{array}{l}\text { COVID-19 Hospital } \\
\text { Deaths Age } 70-79(\%)\end{array}$} & \multicolumn{3}{|c|}{$\begin{array}{l}\text { COVID-19 Hospital } \\
\text { Deaths Age } 80-89(\%)\end{array}$} \\
\hline $\mathrm{N}$ & 126 & 187 & 146 & 126 & 187 & 146 & 126 & 187 & 146 \\
\hline Minimum & 0.00 & 0.00 & 0.00 & 0.00 & 0.00 & 8.54 & 0.00 & 0.00 & 5.41 \\
\hline Maximum & 28.86 & 31.19 & 36.97 & 19.83 & 21.31 & 50.00 & 13.96 & 23.75 & 25.00 \\
\hline Mean & 25.82 & 28.54 & 25.58 & 18.11 & 20.01 & 21.28 & 11.74 & 10.61 & 13.40 \\
\hline Std. Deviation & 2.74 & 4.27 & 6.93 & 2.18 & 3.12 & 5.43 & 2.28 & 1.94 & 3.24 \\
\hline
\end{tabular}

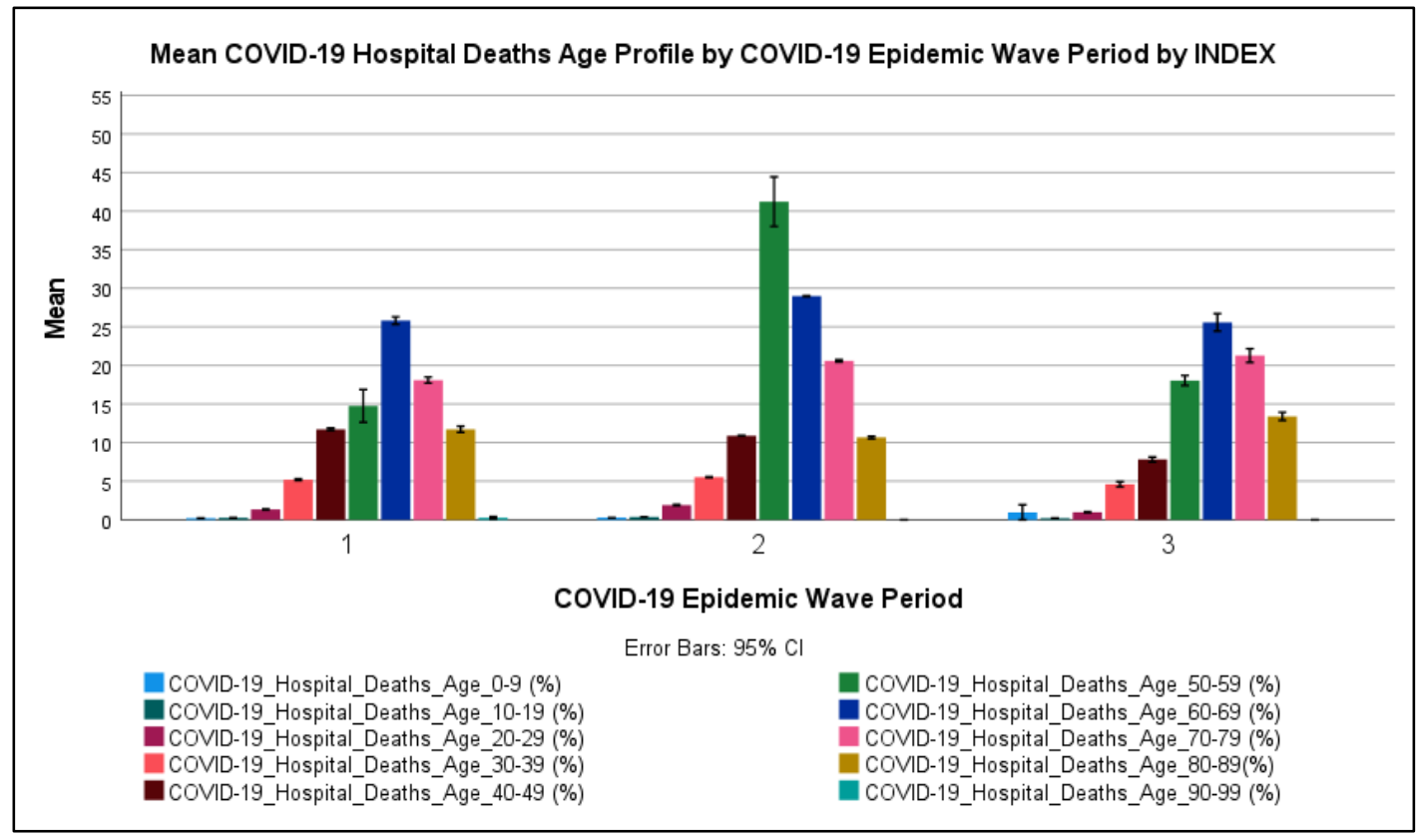

Figure 6: The mean COVID-19 Hospitalised Death Age Profile (with $95 \%$ Confidence Interval (CI) Error Bars) in the First, Second and Third COVID-19 Epidemic Wave Period in South Africa 
medRxiv preprint doi: https://doi.org/10.1101/2021.10.22.21265316; this version posted October 25, 2021. The copyright holder for this preprint (which was not certified by peer review) is the author/funder, who has granted medRxiv a license to display the preprint in perpetuity.

It is made available under a CC-BY 4.0 International license.

Figure 6 shows that most COVID-19 hospitalised deaths in South Africa in the first, second and third COVID-19 epidemic wave period were in the ages of 60 to 69 (25.8\%), 50 to $59(41.2 \%)$ and 60 to $69(25.6 \%)$ years respectively. COVID-19 hospitalised deaths in the age groups of 70 to 79 were the second-largest death age groups in the first and third COVID-19 epidemic wave period (18.1-21.3\%) while for the second COVID-19 epidemic wave period it was the age group of 60 to 69 years $(28.5 \%)$. COVID-19 hospitalised deaths in the age groups of 0 to 29 years were relatively low (0.194 to $1.97 \%)$. The incidence of COVID-19 deaths in children has been reported to be low around the world [8]. Figure 6 shows that the COVID-19 hospitalised death age profile for the first, second and third COVID-19 epidemic wave periods were similar in distribution except for the high incidence of COVID-19 hospitalised deaths in the age group of 50 to 59 in the second COVID-19 epidemic wave period. In general, paired T-tests of the mean COVID-19 hospitalised deaths age groups between the Pair 1, Pair 2 and Pair 3 showed significant difference at $95 \%$ confidence interval between the respective COVID-19 epidemic periods with p-values in the range of $5.04 \times 10^{-40}$ to 0.00238 respectively (shown in Table 17). Table 17Table 13 shows that the COVID-19 hospitalised deaths in age groups of 0 to 9 years in the first, second and third COVID-19 epidemic wave period were not significantly different at a $95 \%$ confidence interval with p-values of 0.144 to 0.177 .

Table 17: Mean Paired Differences, Standard Deviation (Std.) Paired Differences, Standard Error of Mean (Std. Error Mean), $95 \%$ Confidence Interval (CI) if the Upper and Lower Difference, $t$-value, degrees of freedom (df) and P-value (Sig. (2-tailed) for the COVID-19 Hospitalised Deaths in the Ages of 0 to 9, 10 to 19, 20 to 29, 30 to 39, 40 to 49, 50 to 59, 60 to 69, 70 to 79, 80 to 89 years between Pair 1 ( $1^{\text {st }}$ and $2^{\text {nd }}$ COVID-19 Epidemic Wave Period), Pair 2 (1 $1^{\text {st }}$ and $3^{\text {rd }}$ COVID-19 Epidemic Wave Period) and Pair 3 (2 ${ }^{\text {nd }}$ and $3^{\text {rd }}$ COVID-19 Epidemic Wave Period) in South Africa. (Paired Samples T-Test)

\begin{tabular}{|c|c|c|c|c|c|c|c|c|c|}
\hline & \multicolumn{3}{|c|}{$\begin{array}{l}\text { COVID-19 Hospital Deaths } \\
\text { Age } 0-9(\%)\end{array}$} & \multicolumn{3}{|c|}{$\begin{array}{l}\text { COVID-19 Hospital Deaths } \\
\text { Age } 10-19(\%)\end{array}$} & \multicolumn{3}{|c|}{$\begin{array}{c}\text { COVID-19 Hospital Deaths } \\
\text { Age } 20-29(\%)\end{array}$} \\
\hline Test Pairing & \multicolumn{3}{|c|}{ Pair 1} & \multicolumn{3}{|c|}{ Pair 1} & \multicolumn{3}{|c|}{ Pair 1} \\
\hline Mean Paired Differences & -0.02236 & -0.86738 & -0.81288 & -0.17028 & 0.02690 & 0.18624 & -0.75434 & 0.30540 & 1.08528 \\
\hline Std. Deviation Paired Differences & 0.161 & 6.616 & 6.698 & 0.225 & 0.091 & 0.200 & 0.520 & 0.359 & 0.616 \\
\hline Std. Error Mean & 0.016 & 0.589 & 0.599 & 0.022 & 0.008 & 0.018 & 0.050 & 0.032 & 0.055 \\
\hline $95 \% \mathrm{Cl}$ of the Difference Lower & -0.053 & -2.034 & -1.999 & -0.214 & 0.011 & 0.151 & -0.854 & 0.242 & 0.976 \\
\hline $95 \% \mathrm{Cl}$ of the Difference Upper & 0.009 & 0.299 & 0.373 & -0.127 & 0.043 & 0.222 & -0.654 & 0.369 & 1.194 \\
\hline $\mathrm{t}$ & -1.431 & -1.472 & -1.357 & -7.805 & 3.303 & 10.392 & -14.943 & 9.539 & 19.711 \\
\hline df & 105 & 125 & 124 & 105 & 125 & 124 & 105 & 125 & 124 \\
\hline \multirow[t]{2}{*}{ Sig. (2-tailed) } & 0.155 & 0.144 & 0.177 & $4.67 \mathrm{E}-12$ & 1.25E-03 & $1.41 \mathrm{E}-18$ & 9.57E-28 & $1.55 \mathrm{E}-16$ & $5.04 \mathrm{E}-40$ \\
\hline & \multicolumn{3}{|c|}{$\begin{array}{l}\text { COVID-19 Hospital Deaths } \\
\text { Age } 30-39(\%)\end{array}$} & \multicolumn{3}{|c|}{$\begin{array}{c}\text { COVID-19 Hospital Deaths } \\
\text { Age } 40-49(\%)\end{array}$} & \multicolumn{3}{|c|}{$\begin{array}{l}\text { COVID-19 Hospital Deaths } \\
\text { Age } 50-59(\%)\end{array}$} \\
\hline Mean Paired Differences & -0.784 & 0.294 & 1.374 & 0.847 & 3.480 & 2.876 & -43.419 & -4.415 & 31.079 \\
\hline Std. Deviation Paired Differences & 0.755 & 2.008 & 2.028 & 0.966 & 1.793 & 2.046 & 27.322 & 12.584 & 22.611 \\
\hline Std. Error Mean & 0.073 & 0.179 & 0.181 & 0.094 & 0.160 & 0.183 & 3.036 & 1.126 & 2.261 \\
\hline $95 \% \mathrm{Cl}$ of the Difference Lower & -0.929 & -0.060 & 1.015 & 0.661 & 3.164 & 2.514 & -49.460 & -6.643 & 26.593 \\
\hline $95 \% \mathrm{Cl}$ of the Difference Upper & -0.638 & 0.648 & 1.733 & 1.033 & 3.796 & 3.238 & -37.377 & -2.187 & 35.566 \\
\hline $\mathrm{t}$ & -10.684 & 1.646 & 7.575 & 9.032 & 21.782 & 15.718 & -14.302 & -3.922 & 13.745 \\
\hline df & 105 & 125 & 124 & 105 & 125 & 124 & 80 & 124 & 99 \\
\hline Sig. (2-tailed) & $1.79 \mathrm{E}-18$ & 1.02E-01 & 7.20E-12 & $9.05 \mathrm{E}-15$ & $2.23 \mathrm{E}-44$ & $2.68 \mathrm{E}-31$ & 9.45E-24 & $1.44 \mathrm{E}-04$ & 1.10E-24 \\
\hline & \multicolumn{3}{|c|}{$\begin{array}{c}\text { COVID-19 Hospital Deaths } \\
\text { Age } 60-69(\%)\end{array}$} & \multicolumn{3}{|c|}{$\begin{array}{c}\text { COVID-19 Hospital Deaths } \\
\text { Age } 70-79(\%)\end{array}$} & \multicolumn{3}{|c|}{$\begin{array}{c}\text { COVID-19 Hospital Deaths } \\
\text { Age } 80-89(\%)\end{array}$} \\
\hline Mean Paired Differences & -2.727 & -1.661 & 3.673 & -1.031 & -4.730 & -1.525 & 1.657 & -2.633 & -2.845 \\
\hline Std. Deviation Paired Differences & 6.845 & 5.518 & 9.457 & 4.283 & 4.247 & 7.449 & 3.267 & 2.796 & 4.032 \\
\hline Std. Error Mean & 0.665 & 0.492 & 0.846 & 0.416 & 0.378 & 0.666 & 0.317 & 0.249 & 0.361 \\
\hline $95 \% \mathrm{Cl}$ of the Difference Lower & -4.046 & -2.634 & 1.998 & -1.856 & -5.478 & -2.844 & 1.028 & -3.126 & -3.559 \\
\hline $95 \% \mathrm{Cl}$ of the Difference Upper & -1.409 & -0.688 & 5.347 & -0.206 & -3.981 & -0.206 & 2.286 & -2.140 & -2.131 \\
\hline $\mathrm{t}$ & -4.102 & -3.379 & 4.342 & -2.478 & -12.501 & -2.289 & 5.221 & -10.568 & -7.889 \\
\hline $\mathrm{df}$ & 105 & 125 & 124 & 105 & 125 & 124 & 105 & 125 & 124 \\
\hline Sig. (2-tailed) & $8.10 \mathrm{E}-05$ & $9.70 \mathrm{E}-04$ & 2.91E-05 & $1.48 \mathrm{E}-02$ & $9.22 \mathrm{E}-24$ & $2.38 \mathrm{E}-02$ & 9.03E-07 & 4.81E-19 & 1.36E-12 \\
\hline
\end{tabular}


medRxiv preprint doi: https://doi.org/10.1101/2021.10.22.21265316; this version posted October 25, 2021. The copyright holder for this preprint (which was not certified by peer review) is the author/funder, who has granted medRxiv a license to display the preprint in perpetuity.

It is made available under a CC-BY 4.0 International license.

Table 18 shows the cumulative COVID-19 death risk ratio for South African COVID-19 hospital death age groups for the first, second and third COVID-19 epidemic wave period in South Africa regarding the age group of 0 to 9 years. The cumulative risk of death in COVID-19 hospitalised deaths increased with increasing age group groups with age groups of 50 to 69 years having the highest risk.

Table 18: Cumulative COVID-19 Death Risk Ratio (CFARR) for South African hospital Death Age Groups (Age Group 0-9 as reference (Ref)) for the First, Second and Third COVID-19 Epidemic Wave Period in South Africa (Cumulative Risk)

\begin{tabular}{|l|c|c|c|}
\hline \multicolumn{4}{|c|}{ Cumulative Risk Ratios } \\
\hline & 1 & 2 & 3 \\
\hline COVID-19 Epidemic Wave Period & 1.00 & 1.00 & 1.00 \\
\hline COVID-19 Hospital Deaths Age 0-9 (\%) & 1.31 & 1.59 & 0.23 \\
\hline COVID-19 Hospital Deaths Age 10-19 (\%) & 6.91 & 7.85 & 1.05 \\
\hline COVID-19 Hospital Deaths Age 20-29 (\%) & 26.78 & 22.66 & 4.88 \\
\hline COVID-19 Hospital Deaths Age 30-39 (\%) & 60.38 & 43.18 & 8.29 \\
\hline COVID-19 Hospital Deaths Age 40-49 (\%) & 76.01 & 164.86 & 19.13 \\
\hline COVID-19 Hospital Deaths Age 50-59 (\%) & 132.96 & 114.10 & 27.11 \\
\hline COVID-19 Hospital Deaths Age 60-69 (\%) & 93.24 & 80.00 & 22.55 \\
\hline COVID-19 Hospital Deaths Age 70-79 (\%) & 60.47 & 42.42 & 14.20 \\
\hline COVID-19 Hospital Deaths Age 80-89(\%) & & & \\
\hline
\end{tabular}

The results in Section 3.2.4 suggest that the SARS-CoV-2 lineage clusters observed in the first, second and third COVID-19 epidemic wave periods in South Africa resulted in similar distributions of the COVID-19 hospitalised death age profile. The results also show that the SARS-CoV-2 lineage cluster 2 (predominantly Beta (B.1.351) SARS-CoV-2 VOC) resulted in an increase in the incident of hospitalised deaths in age groups of 50 to 59 compared to SARS-CoV-2 lineage cluster 1 (predominantly B.1.1.54, B.1.1.56 C.1 SARS-CoV-2 lineages) and SARS-CoV-2 lineage cluster 3 (predominantly Delta (B.1.617.2) SARS-CoV-2 VOC).

\subsubsection{Impact of SARS-CoV-2 Lineages on the CFR, DR and ECDR}

Table 19 shows the descriptive statistics for the COVID-19 hospital case fatality rate (COVID-19 CRF), hospital discharge rate (COVID-19 DR), natural deaths, excess natural deaths, weekly reported COVID-19 deaths and the weekly unreported excess deaths (natural) to COVID-19 death ratio (ECDR) for the first, second and third COVID-19 epidemic wave periods in South Africa. Table 19 shows that the mean COVID-19 hospital case fatality rate in South Africa's first, second and third COVID-19 epidemic wave periods were 2.06 $\pm 1.10 \%, 2.29 \pm 1.60 \%$ and $2.08 \pm 1.16 \%$ respectively. The mean COVID-19 hospital discharge rate in South Africa's first, second and third COVID-19 epidemic wave periods were $8.40 \pm 4.89 \%, 7.73 \pm 8.89 \%$ and $6.84 \pm 2.72 \%$ respectively. The mean weekly natural deaths in South Africa's first, second and third COVID-19 epidemic wave period were $10398 \pm 2$ 420, $12006 \pm 4301$ and $14506 \pm 2826$ respectively. The mean weekly excess natural deaths in South Africa's first, second and third COVID-19 epidemic wave period were $1619 \pm 2110,3864 \pm 4243$ and $5271 \pm 2636$ respectively. The mean weekly reported COVID-19 deaths in South Africa's first, second and third COVID-19 epidemic wave period were 614 $\pm 556,1226 \pm 1153$ and $1719 \pm 808$ respectively. The Weekly Unreported Excess Deaths (Natural) to COVID-19 Death Ratio (ECDR) allows for the accounting of potential COVID-19 pandemic related natural deaths that are not reported. Table 19 shows the mean ECDR in South Africa's first, second and third COVID-19 epidemic wave period were $1.06 \pm 1.68,2.17 \pm 1.07$ and $2.27 \pm 0.99$ respectively. These results suggest that the number of excess natural deaths not accounted for in the COVID-19 reported deaths were the same as the COVID19 reported deaths in the first COVID-19 epidemic wave period and twice the COVID-19 reported deaths in the second and third COVID-19 epidemic wave period.

Paired T-tests of the COVID-19 hospital case fatality rate in Pair 1, Pair 2 and Pair 3 showed no significant difference at $99 \%$ confidence interval with p-values of $0.028,0.431$ and 0.146 respectively (shown in Table 20). This result suggests that the mean COVID-19 hospital case fatality rates in South Africa's three COVID-19 epidemic wave periods were statistically similar. Paired T-tests of the COVID-19 hospital discharge rate in Pair 1 and Pair 3 showed no significant difference at $95 \%$ confidence interval with p-values of 0.703 and 0.179 respectively (shown in Table 20). While the paired T-test in Pair 2 showed a significant difference at a $95 \%$ 
medRxiv preprint doi: https://doi.org/10.1101/2021.10.22.21265316; this version posted October 25, 2021. The copyright holder for this preprint (which was not certified by peer review) is the author/funder, who has granted medRxiv a license to display the preprint in perpetuity.

It is made available under a CC-BY 4.0 International license.

confidence interval with a p-value of 0.005 . This result suggests that the mean COVID-19 hospital discharge rate in the first and second, second and third COVID-19 epidemic wave periods were statistically similar while that between the first and third COVID-19 wave periods were different. Paired T-tests of the excess natural deaths, weekly reported COVID-19 deaths and ECDR in Pair 3 showed no significant difference at $95 \%$ confidence interval with p-values of $0.908,0.918$ and 0.760 respectively (shown in Table 20). While the paired T-test in Pair 1 and Pair 2 showed a significant difference at a $95 \%$ confidence interval with p-values in the range of 0.001 and $3.64 \times 10^{-06}$ to 0.015 (shown in Table 20). These results suggest that the mean excess natural deaths weekly reported COVID-19 deaths and ECDR in the second and third COVID-19 epidemic wave periods were statistically similar while that between the first and third, first and second COVID-19 wave periods were statistically different.

Table 19: Statistical Sample Number (N), Minimum, Maximum, Mean, Standard Deviation (Std. Deviation) of COVID-19 Hospital Case Fatality Rate (COVID-19 CRF), Hospital Discharge Rate (COVID-19 DR), Weekly Natural Deaths, Excess Natural Deaths, Reported COVID-19 Deaths and the Weekly Unreported Excess Deaths (Natural) to COVID-19 Death Ratio (ECDR) in the First, Second and Third COVID-19 Epidemic Wave Period in South Africa (Descriptive Statistics)

\begin{tabular}{|c|c|c|c|c|c|c|c|c|c|c|c|c|c|c|c|c|c|c|}
\hline \multicolumn{19}{|c|}{ Descriptive Statistics } \\
\hline & \multicolumn{3}{|c|}{ COVID-19 CFR } & \multicolumn{3}{|c|}{ COVID-19 DR } & \multicolumn{3}{|c|}{ Natural Deaths } & \multicolumn{3}{|c|}{$\begin{array}{c}\text { Excess Natural } \\
\text { Deaths }\end{array}$} & \multicolumn{3}{|c|}{$\begin{array}{c}\text { Weekly Reported } \\
\text { COVID-19 } \\
\text { Deaths }\end{array}$} & \multicolumn{3}{|c|}{ ECDR } \\
\hline $\begin{array}{l}\text { Epidemic } \\
\text { Wave } \\
\text { Period }\end{array}$ & 1 & 2 & 3 & 1 & 2 & 3 & 1 & 2 & 3 & 1 & 2 & 3 & 1 & 2 & 3 & 1 & 2 & 3 \\
\hline $\mathrm{N}$ & 121 & 183 & 146 & 121 & 183 & 146 & 30 & 30 & 18 & 29 & 30 & 18 & 30 & 30 & 18 & 30 & 30 & 18 \\
\hline Minimum & $0.00 \%$ & $0.00 \%$ & $0.09 \%$ & $0.00 \%$ & $-25.62 \%$ & $-3.91 \%$ & 7932 & 9027 & 10690 & 871 & 831 & 1899 & 1 & 281 & 566 & -0.49 & 0.41 & 0.93 \\
\hline Maximum & $6.87 \%$ & $12.89 \%$ & $10.11 \%$ & $42.52 \%$ & $77.62 \%$ & $15.96 \%$ & 15864 & 24198 & 19873 & 6673 & 16106 & 10253 & 2057 & 4027 & 2812 & 5.69 & 4.67 & 4.64 \\
\hline Mean & $2.06 \%$ & $2.29 \%$ & $2.08 \%$ & $8.40 \%$ & $7.73 \%$ & $6.84 \%$ & 10398 & 12006 & 14506 & 1619 & 3864 & 5271 & 614 & 1226 & 1719 & 1.06 & 2.17 & 2.27 \\
\hline $\begin{array}{c}\text { Std. } \\
\text { Deviation }\end{array}$ & $1.10 \%$ & $1.60 \%$ & $1.16 \%$ & $4.89 \%$ & $8.98 \%$ & $2.72 \%$ & 2420 & 4301 & 2826 & 2110 & 4243 & 2636 & 556 & 1153 & 808 & 1.68 & 1.07 & 0.99 \\
\hline
\end{tabular}

Table 20: Mean Paired Differences, Standard Deviation (Std.) Paired Differences, Standard Error of Mean (Std. Error Mean), $95 \%$ Confidence Interval (CI) if the Upper and Lower Difference, $t$-value, degrees of freedom (df) and P-value (Sig. (2-tailed) for the COVID-19 Hospital Case Fatality Rate (COVID-19 CRF), Hospital Discharge Rate (COVID-19 DR), Natural Deaths, Excess Natural Deaths, Weekly Reported COVID-19 Deaths and the Weekly Unreported Excess Deaths (Natural) to COVID19 Death Ratio (ECDR)between Pair 1 ( $1^{\text {st }}$ and $2^{\text {nd }}$ COVID-19 Epidemic Wave Period), Pair 2 ( $1^{\text {st }}$ and $3^{\text {rd }}$ COVID-19 Epidemic Wave Period) and Pair 3 ( $2^{\text {nd }}$ and $3^{\text {rd }}$ COVID-19 Epidemic Wave Period) in South Africa. (Paired Samples T-Test)

\begin{tabular}{|c|c|c|c|c|c|c|c|c|c|c|c|c|c|c|c|}
\hline \multirow[b]{2}{*}{ Test Pairing } & \multicolumn{3}{|c|}{ COVID-19 CFR } & \multicolumn{3}{|c|}{\begin{tabular}{|c|} 
COVID-19 Discharge \\
Rate \\
\end{tabular}} & \multicolumn{3}{|c|}{$\begin{array}{c}\text { Excess Natural } \\
\text { Deaths }\end{array}$} & \multicolumn{3}{|c|}{$\begin{array}{l}\text { Weekly Reported } \\
\text { COVID-19 Deaths }\end{array}$} & \multicolumn{3}{|c|}{$\begin{array}{l}\text { Excess (Natural) to } \\
\text { Natural_Deaths (\%) }\end{array}$} \\
\hline & Pair 1 & Pair 2 & Pair 3 & Pair 1 & Pair 2 & Pair 3 & Pair 1 & Pair 2 & Pair 3 & Pair 1 & Pair 2 & Pair 3 & Pair 1 & Pair 2 & Pair 3 \\
\hline Mean Paired Differences & -0.005 & -0.001 & 0.003 & 0.004 & 0.015 & 0.014 & -2341 & -3945 & 127 & -612 & -1349 & -22 & -14.57 & -24.53 & -1.13 \\
\hline Std. Deviation Paired Differences & 0.020 & 0.016 & 0.020 & 0.111 & 0.057 & 0.112 & 4660 & 4088 & 4553 & 1296 & 852 & 905 & 20.06 & 20.53 & 15.44 \\
\hline Std. Error Mean & 0.002 & 0.001 & 0.002 & 0.011 & 0.005 & 0.010 & 865 & 992 & 1073 & 237 & 201 & 213 & 3.66 & 4.84 & 3.64 \\
\hline $95 \% \mathrm{Cl}$ of the Difference Lower & -0.009 & -0.004 & -0.001 & -0.018 & 0.004 & -0.006 & -4113 & -6047 & -2137 & -1096 & -1773 & -472 & -22.06 & -34.74 & -8.81 \\
\hline $95 \% \mathrm{Cl}$ of the Difference Upper & 0.000 & 0.002 & 0.006 & 0.026 & 0.025 & 0.034 & -568 & -1843 & 2390 & -128 & -925 & 428 & -7.08 & -14.32 & 6.55 \\
\hline $\mathrm{t}$ & -2.227 & -0.790 & 1.463 & 0.383 & 2.834 & 1.350 & -3 & -4 & 0 & -3 & -7 & 0 & -3.98 & -5.07 & -0.31 \\
\hline df & 98 & 120 & 120 & 98 & 120 & 120 & 28 & 16 & 17 & 29 & 17 & 17 & 29.00 & 17.00 & 17.00 \\
\hline Sig. (2-tailed) & 0.028 & 0.431 & 0.146 & 0.703 & 0.005 & 0.179 & 0.011 & 0.001 & 0.908 & 0.015 & $3.64 \mathrm{E}-06$ & 0.918 & 4.25E-04 & 9.47E-05 & 0.760 \\
\hline
\end{tabular}

The results in Section 3.2.5 suggest that the SARS-CoV-2 lineage clusters identified in the first, second and third COVID-19 epidemic wave periods in South Africa resulted in similar COVID-19 hospital case-fatality rates. The SARS-CoV-2 lineage cluster 2 (predominantly Beta (B.1.351) SARS-CoV-2 VOC) and the SARS-CoV-2 lineage cluster 3 (predominantly Delta (B.1.617.2) SARS-CoV-2 VOC) resulted in similar COVID-19 discharge rates, excess natural deaths, weekly reported COVID-19 deaths and ECDR. While, the SARS-CoV-2 lineage cluster 1 (predominantly B.1.1.54, B.1.1.56 C.1 SARS-CoV-2 lineages) resulted in statistically different excess natural deaths, weekly reported COVID-19 deaths and ECDR relative to the aforementioned SARS-CoV-2 clusters. 
medRxiv preprint doi: https://doi.org/10.1101/2021.10.22.21265316; this version posted October 25, 2021. The copyright holder for this preprint (which was not certified by peer review) is the author/funder, who has granted medRxiv a license to display the preprint in

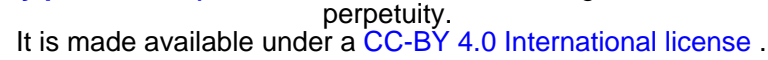

\section{Conclusions}

Based on the COVID-19 detection rate in South Africa, the SA SARS-CoV-2 lineage cluster 3 which was predominantly the Delta (B.1.617.2) SARS-CoV-2 VOC resulted in an increase in the COVID-19 transmissibility in the South African population by 53.9 to $54.8 \%$. This is relative to the SA SARS-CoV-2 lineage cluster 1 (predominantly B.1.1.54, B.1.1.56 C.1 SARS-CoV-2 lineages) and the SA SARS-CoV-2 lineage cluster 2 (predominantly Beta (B.1.351) SARS-CoV-2 VOC) respectively. The SA SARS-CoV-2 lineage cluster 1 and 2 resulted in similar COVID-19 transmissibility in the South African population.

Based on the daily COVID-19 hospitalisations per active case, the SA SARS-CoV-2 lineage cluster 2 (predominantly the Beta (B.1.351) SARS-CoV-2 VOC) was observed to result in increased hospitalisation relative to the SA SARS-CoV-2 lineage clusters 1 and 3. COVID-19 hospitalisations per active case were observed to have increased by $113 \%$ and $36.8 \%$ respectively. While the SA SARS-CoV-2 lineage cluster 3 (predominantly the Delta (B.1.617.2) SARS-CoV-2 VOC) was also observed to have resulted in an increased COVID-19 hospitalisation relative to the SA SARS-CoV-2 lineage cluster 1. The COVID-19 hospitalisations per active case increased by $55.8 \%$. SA SARS-CoV-2 lineage clusters 1,2 and 3 resulted in a similar distribution of the COVID19 hospital admission status profile in South African hospitals. Most COVID-19 hospitalised cases in South Africa were hospitalised in the general ward (72.8-78.7\%). COVID-19 patients on oxygen were the second-largest hospital admission status (16.8-27.6\%) in South Africa followed by the COVID-19 patients in the intensive care unit (14.1-16.7\%). SA SARS-CoV-2 lineage clusters 1 and 3 resulted in the same COVID-19 patients admitted to the intensive care unit. While the SA SARS-CoV-2 lineage cluster 2 resulted in higher COVID-19 patients on oxygen than the SA SARS-CoV-2 lineage clusters 1 and 3. This result highlights the increased COVID-19 severity due to the Beta SARS-CoV-2 VOC. The SA SARS-CoV-2 lineage clusters 1, 2 and 3 resulted in different distributions of the COVID-19 hospital admission age profile. Most COVID-19 hospitalised cases in South Africa were in the ages of 50 to 69 years. COVID-19 patients in the age groups of 40 to 49 years were the second-largest hospital admitted age group in South Africa. COVID-19 admitted patients in the age groups of 0 to 19 years were relatively low (1.8 to $4.4 \%)$ and highest in the second COVID-19 epidemic wave period. The SA SARS-CoV-2 lineage cluster 3 (predominantly the Delta (B.1.617.2) SARS-COV-2 VOC) resulted in an increased incidence in COVID-19 patients in the age groups over 70 years compared to the SA SARS-CoV-2 lineage clusters 1 and 2. The SA SARS-CoV-2 lineage clusters 1, 2 and 3 resulted in a similar distribution of the COVID-19 hospitalised death age profile. Most COVID-19 hospitalised deaths in South Africa in the first, second and third COVID-19 epidemic wave period were in the ages of 50 to 69 years. COVID-19 hospitalised deaths in the age groups of 0 to 29 years in South Africa were relatively low $(0.194$ to $1.97 \%)$. The cumulative risk of death in COVID-19 hospitalised deaths increased with increasing age group groups with age groups of 50 to 69 years having the highest risk. The SA SARS-CoV-2 lineage cluster 2 (predominantly the Beta (B.1.351) SARS-CoV-2 VOC) resulted in an increase in the incidence of hospitalised deaths in age groups of 50 to 59 compared to the SARSCoV-2 lineage clusters 1 and 3.

The mean COVID-19 hospital case fatality rate in South Africa's first, second and third COVID-19 epidemic wave periods were $2.06 \pm 1.10 \%, 2.29 \pm 1.60 \%$ and $2.08 \pm 1.16 \%$ respectively. The number of excess natural deaths not accounted for in the COVID-19 reported deaths were the same as the COVID-19 reported deaths in the first COVID-19 epidemic wave period and twice the COVID-19 reported deaths in the second and third COVID-19 epidemic wave period. The SA SARS-CoV-2 lineage clusters 1, 2 and 3 resulted in similar COVID-19 hospital case-fatality rates in South Africa. While the SA SARS-CoV-2 lineages clusters 2 and 3 resulted in similar COVID-19 discharge rates, excess natural deaths, weekly reported COVID-19 deaths and ECDR in South Africa. The SA SARS-CoV-2 lineage cluster 1 (predominantly the B.1.1.54, B.1.1.56 C.1 SARS-CoV-2 lineages) resulted in statistically different excess natural deaths, weekly reported COVID-19 deaths and ECDR in South Africa relative to the aforementioned SARS-CoV-2 clusters.

This study shows that the evolution of SARS-CoV-2 resulted in an increase in COVID-19 transmissibility and severity in South Africa. The Delta SARS-CoV-2 VOC resulted in increased COVID-19 transmissibility in the South African population while both the Beta SARS-CoV-2 VOC and Delta SARS-CoV-2 VOC resulted in more severe COVID-19 than the initial SARS-CoV-2 lineages detected in South Africa's first epidemic wave period. 
medRxiv preprint doi: https://doi.org/10.1101/2021.10.22.21265316; this version posted October 25, 2021. The copyright holder for this preprint (which was not certified by peer review) is the author/funder, who has granted medRxiv a license to display the preprint in

It is made available under a CC-BY 4.0 International license.

\section{Acknowledgements}

ARI would like to thank the members of the ARI African Disease Demographic Research Group (ADDRG) and African COVID-19 Modelling Research Group (ACMRG) for their voluntary commitment to working in the ARI COVID-19 Research Project. We acknowledge the work by the National Institute for Communicable Diseases (NICD), Western Cape Department of Health Provincial Health Data Centre (PHDC), South African Medical Research Council (SAMRC) and the Network for Genomics Surveillance in South Africa (NGS-SA) in which the ARI COVID-19 Project draws a lot of its data from. Lastly, we want to salute the scientific community, governments, health care workers, essential personnel in their response to the pandemic and we pay homage to those who have lost their lives due to the COVID-19 pandemic.

\section{Funding and Conflict of interests}

This study falls under the ARI COVID-19 Research Project of which the project is currently not funded. Data used in this study was obtained from public sources.

\section{References}

1. WHO. Rolling updates on coronavirus disease (COVID-19) [Internet]. 2020 WHO. 2020 [cited 2020 Jun 22]. Available from: https://www.who.int/emergencies/diseases/novel-coronavirus-2019/events-as-they-happen

2. JHU CSSE. Novel Coronavirus (COVID-19) Cases Data [Internet]. Johns Hopkins Univ. Cent. Syst. Sci. Eng. (JHU CCSE). 2021 [cited 2021 Oct 3]. p. 1. Available from: https://data.humdata.org/dataset/novel-coronavirus2019-ncov-cases

3. World Bank Group. JUNE 2021 Global Economic Prospects [Internet]. Glob. Econ. Prospect. Washington DC; 2021. Available from: https://openknowledge.worldbank.org/bitstream/handle/10986/35647/9781464816659.pdf

4. UNDP, WHO, BSG. Vaccine inequity undermining global economic recovery. Jt News Release [Internet]. Geneva/New York City; 2021 Jul 22; Available from: https://www.who.int/news/item/22-07-2021-vaccineinequity-undermining-global-economic-recovery

5. Korber B, Fischer WM, Gnanakaran S, Yoon H, Theiler J, Abfalterer W, et al. Tracking Changes in SARSCoV-2 Spike: Evidence that D614G Increases Infectivity of the COVID-19 Virus. Cell [Internet]. 2020;182:812827.e19. Available from: file:///C:/Users/ThaboMabuka/Downloads/1-s2.0-S0092867420308205-main.pdf

6. Queiroz K De. The General Lineage Concept of Species and the Defining Properties of the Species Category. In: Howard DJ, Berlocher SH, editors. Endless Forms: Species and Speciation [Internet]. Oxford: Oxford University Press; $1998 . \quad$ p. $57-75 . \quad$ Available from: https://repository.si.edu/bitstream/handle/10088/4652/VZ_1998deQueirozEndlessForms.pdf

7. Dyson L, Hill EM, Moore S, Curran-sebastian J, Tildesley MJ, Lythgoe KA, et al. Possible future waves of SARS-CoV-2 infection generated by variants of concern with a range of characteristics. Nat Commun [Internet]. Springer US; 2021; Available from: http://dx.doi.org/10.1038/s41467-021-25915-7

8. WHO. Report of the WHO-China Joint Mission on Coronavirus Disease 2019 (COVID-19). WHO-China Jt Mission Coronavirus Dis 2019 [Internet]. 2020;1:40. Available from: https://www.who.int/publicationsdetail/report-of-the-who-china-joint-mission-on-coronavirus-disease-2019-(covid-

19)\%0Ahttps://www.who.int/docs/default-source/coronaviruse/who-china-joint-mission-on-covid-19-finalreport.pdf

9. Wu F, Zhao S, Yu B, Chen YM, Wang W, Song ZG, et al. A new coronavirus associated with human respiratory disease in China. Nature [Internet]. 2020;579:265-9. Available from: https://www.nature.com/articles/s41586020-2008-3.pdf

10. Raskin S. Genetics of COVID-19. J Pediatr (Rio J) [Internet]. 2021;97:378-86. Available from: https://pubmed.ncbi.nlm.nih.gov/31987001/

11. Shereen MA, Khan S, Kazmi A, Bashir N, Siddique R. COVID-19 infection: Origin, transmission, and characteristics of human coronaviruses. J Adv Res [Internet]. THE AUTHORS; 2020;24:91-8. Available from: https://doi.org/10.1016/j.jare.2020.03.005

12. Cella E, Benedetti F, Fabris S, Borsetti A, Pezzuto A, Ciotti M, et al. SARS-CoV-2 Lineages and Sub-Lineages Circulating Worldwide: A Dynamic Overview. Chemotherapy [Internet]. 2021;66:3-7. Available from: https://www.karger.com/Article/FullText/515340 
medRxiv preprint doi: https://doi.org/10.1101/2021.10.22.21265316; this version posted October 25, 2021. The copyright holder for this preprint (which was not certified by peer review) is the author/funder, who has granted medRxiv a license to display the preprint in

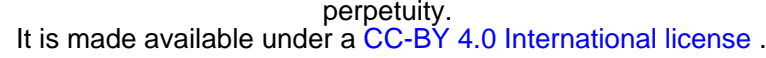

13. Cascella M, Rajnik M, Cuomo A, Dulebohn SC, Di Napoli R. Features, Evaluation, and Treatment of Coronavirus. StatPearls [Internet]. 2020;19. Available from: http://www.ncbi.nlm.nih.gov/pubmed/32150360

14. Romano M, Ruggiero A, Squeglia F, Maga G, Berisio R. A Structural View of SARS-CoV-2 RNA Replication Machinery: RNA Synthesis, Proofreading and Final Capping. Cells [Internet]. 2020;9. Available from: https://www.ncbi.nlm.nih.gov/pmc/articles/PMC7291026/pdf/cells-09-01267.pdf

15. Finkel Y, Mizrahi O, Nachshon A, Weingarten-Gabbay S, Morgenstern D, Yahalom-Ronen Y, et al. The coding capacity of SARS-CoV-2. Nature [Internet]. Springer US; 2021;589:125-30. Available from: http://dx.doi.org/10.1038/s41586-020-2739-1

16. Izaguirre G. The Proteolytic Regulation of Virus Cell Entry by Furin and Other Proprotein Convertases. Viruses [Internet]. 2019;11:1-19. Available from: https://www.ncbi.nlm.nih.gov/pmc/articles/PMC6784293/pdf/viruses-11-00837.pdf

17. Lu R, Zhao X, Li J, Niu P, Yang B, Wu H, et al. Genomic characterisation and epidemiology of 2019 novel coronavirus: implications for virus origins and receptor binding. Lancet [Internet]. Elsevier Ltd; 2020;395:56574. Available from: http://dx.doi.org/10.1016/S0140-6736(20)30251-8

18. Rambaut A, Holmes EC, O’Toole Á, Hill V, McCrone JT, Ruis C, et al. A dynamic nomenclature proposal for SARS-CoV-2 lineages to assist genomic epidemiology. Nat Microbiol [Internet]. Springer US; 2020;5:14037. Available from: http://dx.doi.org/10.1038/s41564-020-0770-5

19. O’Toole Á, Scher E, Underwood A, Jackson B, Hill V, McCrone JT, et al. Assignment of Epidemiological Lineages in an Emerging Pandemic Using the Pangolin Tool. Virus Evol [Internet]. 2021;7:1-9. Available from: https://watermark.silverchair.com/veab064.pdf?token=AQECAHi208BE49Ooan9kkhW_Ercy7Dm3ZL_9Cf3qf KAc485ysgAAAr8wggK7BgkqhkiG9w0BBwagggKsMIICqAIBADCCAqEGCSqGSIb3DQEHATAeBglghkg BZQMEAS4wEQQMP10Q5kKsgswQIyYAgEQgIICcvYxjaKS5tJip9doT8tw2asRJSGPjdxeaY9pH3M3g_3rUCN

20. Cevik M, Kuppalli K, Kindrachuk J, Peiris M. Virology, transmission, and pathogenesis of SARS-CoV-2. BMJ. 2020;371:1-6.

21. WHO. Tracking SARS-CoV-2 variants [Internet]. Activities. 2021 [cited 2021 Oct 3]. Available from: https://www/who.int/en/activities/tracking-SARS-CoV-2-variants/

22. CDC. SARS-CoV-2 Variant Classifications and Definitions [Internet]. Var. Surveill. 2021 [cited 2021 Oct 3]. p. 1. Available from: https://www.cdc.gov/coronavirus/2019-ncov/variants/variant-info.html

23. Volz E, Mishra S, Chand M, Barrett JC, Johnson R, Geidelberg L, et al. Assessing transmissibility of SARSCoV-2 lineage B.1.1.7 in England. Nature. 2021;593:266-9.

24. Frampton D, Rampling T, Cross A, Bailey H, Heaney J, Byott M, et al. Genomic characteristics and clinical effect of the emergent SARS-CoV-2 B.1.1.7 lineage in London, UK: a whole-genome sequencing and hospitalbased cohort study. Lancet Infect Dis [Internet]. The Author(s). Published by Elsevier Ltd. This is an Open Access article under the CC BY-NC-ND 4.0 license; 2021;21:1246-56. Available from: http://dx.doi.org/10.1016/S14733099(21)00170-5

25. Mazumder R, Abdullah A, Hossain ME, Rahman MM, Bin Manjur OH, Rahman M, et al. Genome Sequencing Identified a SARS-CoV-2 Lineage B.1.1.7 Strain with a High Number of Mutations from Dhaka, Bangladesh. Microbiol Resour Announc [Internet]. 2021;10:27-9. Available from: https://www.ncbi.nlm.nih.gov/pmc/articles/PMC8201627/pdf/mra.00345-21.pdf

26. Davies NG, Abbott S, Barnard RC, Jarvis CI, Kucharski AJ, Munday JD, et al. Estimated transmissibility and impact of SARS-CoV-2 lineage B.1.1.7 in England. Science (80- ) [Internet]. 2021;372. Available from: https://www.ncbi.nlm.nih.gov/pmc/articles/PMC8128288/pdf/372_abg3055.pdf

27. Faria NR, Mellan TA, Whittaker C, Claro IM, Candido D da S, Mishra S, et al. Genomics and epidemiology of the P.1 SARS-CoV-2 lineage in Manaus, Brazil. Science (80- ) [Internet]. 2021;815-21. Available from: https://www.science.org/doi/epdf/10.1126/science.abh2644

28. Wang P, Casner RG, Nair MS, Wang M, Yu J, Cerutti G, et al. Increased resistance of SARS-CoV-2 variant P.1 to antibody neutralization. Cell Host Microbe 29, [Internet]. 2021;19-21. Available from: https://www.ncbi.nlm.nih.gov/pmc/articles/PMC8053237/pdf/main.pdf 
medRxiv preprint doi: https://doi.org/10.1101/2021.10.22.21265316; this version posted October 25, 2021. The copyright holder for this preprint (which was not certified by peer review) is the author/funder, who has granted medRxiv a license to display the preprint in

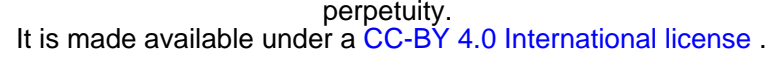

29. Mlcochova P, Kemp S, Dhar MS, Papa G, Meng B, Ferreira IATM, et al. SARS-CoV-2 B.1.617.2 Delta variant replication and immune evasion. Nature [Internet]. 2021; Available from: https://www.nature.com/articles/s41586-021-03944-y_reference.pdf

30. Planas D, Veyer D, Baidaliuk A, Staropoli I, Guivel-Benhassine F, Rajah MM, et al. Reduced sensitivity of SARS-CoV-2 variant Delta to antibody neutralization. Nature [Internet]. Springer US; 2021;596:276-80. Available from: http://dx.doi.org/10.1038/s41586-021-03777-9

31. WHO. COVID-19 Weekly Epidemiological Update 47 [Internet]. COVID-19 Wkly. Epidemiol. Updat. Data. Geneva, Switzerland; 2021. Available from: https://www.who.int/docs/default-source/coronaviruse/situationreports/20210511_weekly_epi_update_39.pdf

32. Cherian S, Potdar V, Jadhav S, Yadav P, Gupta N, Das M, et al. SARS-CoV-2 Spike Mutations, L452R, T478K, E484Q and P681R, in the Second Wave of COVID-19 in Maharashtra, India. Microorganisms [Internet]. 2021;9:1-11. Available from: https://www.nature.com/articles/s41586-021-03944-y_reference.pdf

33. Rosa G La, Brandtner D, Mancini P, Veneri C, Ferraro GB, Bonadonna L, et al. Key SARS-CoV-2 Mutations of Alpha, Gamma , and Eta Variants Detected in Urban Wastewaters in Italy by Long-Read Amplicon Sequencing Based on Nanopore Technology. Water [Internet]. 2021;13. Available from: https://www.mdpi.com/2073$4441 / 13 / 18 / 2503$

34. Duerr R, Dimartino D, Marier C, Zappile P, Wang G, Lighter J, et al. Dominance of Alpha and Iota variants in SARS-CoV-2 vaccine breakthrough infections in New York City. J Clin Invest [Internet]. 2021;131. Available from: https://www.jci.org/articles/view/152702/pdf

35. Janik E, Niemcewicz M, Podogrocki M, Majsterek I, Bijak M. The emerging concern and interest sars-cov-2 variants. Pathogens [Internet]. 2021;10:1-13. Available from: file:///C:/Users/ThaboMabuka/Downloads/pathogens-10-00633-v2.pdf

36. Romero PE, Dávila-Barclay A, Salvatierra G, González L, Cuicapuza D, Solis L, et al. The Emergence of SARS-CoV-2 Variant Lambda (C.37) in South America. medRxiv [Internet]. 2021;2021.06.26.21259487. Available

from: https://www.medrxiv.org/content/10.1101/2021.06.26.21259487v1\%0Ahttps://www.medrxiv.org/content/10.11 01/2021.06.26.21259487v1.abstract

37. Kimura I, Kosugi Y, Wu J, Yamasoba D, Butlertanaka EP, Tanaka YL, et al. SARS-CoV-2 Lambda variant exhibits higher infectivity and immune 2 resistance. bioRxiv Prepr [Internet]. 2021;1-31. Available from: https://www.biorxiv.org/content/10.1101/2021.07.28.454085v1.full.pdf

38. NICD. NATIONAL COVID-19 DAILY REPORT [Internet]. Natl. COVID-19 Situat. Summ. 2021 [cited 2021 Oct 3]. p. 1. Available from: nicd.ac.za/diseases-a-z-index/disease-index-covid-19/surveillancereports/national-covid-19-daily-report/

39. NICD. The initial and daily covid-19 effective reproductive number (R) in South Africa. Cape Town; 2020.

40. NICD. FIRST CASE OF COVID-19 CORONAVIRUS REPORTED IN SA [Internet]. 2020 [cited 2020 Jul 6]. Available from: https://www.nicd.ac.za/first-case-of-covid-19-coronavirus-reported-in-sa/\#: :text=This morning\%2C Thursday March 5,Africa on March 1\%2C 2020.

41. Blumberg L, Frean J. COVID-19 SECOND WAVE IN SOUTH AFRICA [Internet]. Cape Town, South Africa; 2020. Available from: https:/www.nicd.ac.za/covid-19-second-wave-in-south-africa/

42. Government of South Africa. President Cyril Ramaphosa: Escalation of measures to combat Coronavirus COVID-19 pandemic [Internet]. 2020 [cited 2020 Jul 7]. Available from: https://www.gov.za/speeches/presidentcyril-ramaphosa-escalation-measures-combat-coronavirus-covid-19-pandemic-23-mar

43. Government of South Africa. Disaster Management Act (57/2002): Regulations made in terms of Section 27(2) by the Minister of Cooperative Governance and Traditional Affairs. Gov Gaz [Internet]. 2020; Available from: https://www.justice.gov.za/legislation/notices/2020/20200325-gg43148-GoN398-COVID19COGTA.pdf.pdf

44. Government of South Africa. Alert Level 5 [Internet]. Pretoria; 2020. Available from: https://www.gov.za/documents/disaster-management-act-regulations-address-prevent-and-combat-spreadcoronavirus-covid-19 
medRxiv preprint doi: https://doi.org/10.1101/2021.10.22.21265316; this version posted October 25, 2021. The copyright holder for this preprint (which was not certified by peer review) is the author/funder, who has granted medRxiv a license to display the preprint in

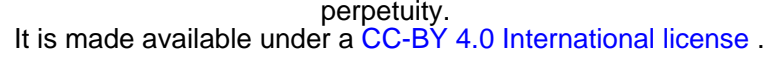

45. Government of South Africa. Alert Level 3 [Internet]. Pretoria; 2020. Available from: https://www.gov.za/coronavirus/alert-level-3

46. Government of South Africa. Alert Level 4 [Internet]. Pretoria; 2020. Available from: https://www.gov.za/coronavirus/alert-level-4

47. Government of South Africa. COVID-19 Coronavirus vaccine strategy [Internet]. COVID-19 / Nov. CORONAVIRUS. 2021 [cited 2021 Oct 3]. p. 1. Available from: https://www.gov.za/covid-19/vaccine/strategy

48. Global Change Data Lab. Coronavirus (COVID-19) Vaccinations [Internet]. Our World Data. 2021 [cited 2021 Oct 3]. p. 1. Available from: https://ourworldindata.org/covid-vaccinations

49. Tegally H, Wilkinson E, Lessells RJ, Giandhari J, Pillay S, Msomi N, et al. Sixteen novel lineages of SARSCoV-2 in South Africa. Nat Med [Internet]. Springer US; 2021;27. Available from: http://dx.doi.org/10.1038/s41591-021-01255-3

50. NGS-SA. NGS-SA: NETWORK FOR GENOMIC SURVEILLANCE IN SOUTH AFRICA [Internet]. 2021 [cited 2021 Oct 3]. p. 1. Available from: krisp.org.za/ngs-sa/ngssa_network_for_genomic_surveillance_south_africa/

51. Lessells R, Moosa MY, De Oliveira T. St Augustines Hospital Outbreak Investigation. Final Report 15 May $2020 \quad$ [Internet]. $\quad 2020 . \quad$ Aurban; $\quad$ Available https://www.krisp.org.za/manuscripts/StAugustinesHospitalOutbreakInvestigation_FinalReport_15may2020_co mp.pdf

52. Tegally H, Wilkinson E, Giovanetti M, Iranzadeh A, Fonseca V, Giandhari J, et al. Detection of a SARSCoV-2 variant of concern in South Africa. Nature [Internet]. Springer US; 2021;592:438-43. Available from: http://dx.doi.org/10.1038/s41586-021-03402-9

53. Cele S, Gazy I, Jackson L, Hwa SH, Tegally H, Lustig G, et al. Escape of SARS-CoV-2 501Y.V2 from neutralization by convalescent plasma. Nature [Internet]. 2021;593:142-6. Available from: https://www.nature.com/articles/s41586-021-03471-w.pdf

54. Elbe S, Buckland-Merrett G, Shu Y, McCauley J. SARS-CoV-2 Sequencing Update 27 September 2021. Track. SARS-COV-2 Var. South Africa; 2021.

55. Scheepers C, Everatt J, Amoako DG, Mnguni A, Ismail A, Mahlangu B, et al. The continuous evolution of SARS-CoV-2 in South Africa: a new lineage with rapid accumulation of mutations of concern and global detection. medRxiv [Internet]. 2021;2021.08.20.21262342. Available from: http://medrxiv.org/content/early/2021/08/24/2021.08.20.21262342.abstract

56. Global Change Data Lab. Coronavirus (COVID-19) Testing [Internet]. Stat. Res. 2021 [cited 2021 Oct 4]. p. 1. Available from: https://ourworldindata.org/coronavirus-testing

57. Jassat W, Cohen C, Kufa T, Goldstein S, Masha M, Cowper B, et al. DATCOV: A SENTINEL SURVEILLANCE PROGRAMME FOR HOSPITALISED INDIVIDUALS WITH COVID-19 IN SOUTH AFRICA, 2020 [Internet]. Johannesburg; 2020. Available from: https://www.nicd.ac.za/diseases-a-z-index/covid19/surveillance-reports/

58. Mabuka T, Ncube N, Ross M, Silaji A, Macharia W, Ndemera T, et al. The Impact of Non-Pharmaceutical Interventions on the First COVID-19 Epidemic Wave in South Africa. medRxiv [Internet]. 2021;2021.06.29.21259625. Available

from: http://medrxiv.org/content/early/2021/07/03/2021.06.29.21259625.abstract

59. Aron J, Muellbauer J, Thinking NE, Giattino C, Ritchie H, World O. A pandemic primer on excess mortality statistics and their comparability across countries. 2020;1-42.

60. Bradshaw D, Laubscher R, Dorrington R, Groenewald P, Moultrie T. REPORT ON WEEKLY DEATHS IN SOUTH AFRICA 12 - 18 SEPT 2021 [Internet]. 2021. Available from: https://www.samrc.ac.za/reports/reportweekly-deaths-south-africa

61. Hethcote HW. Three Basic Epidemiological Models. 1989;119-44.

62. Evans MJ, Rosenthal JS. Probability and Statistics The Science of Uncertainty [Internet]. Second Edi. Meas. Uncertain. Probab. Toronto: University of Toronto; 2009. Available from: 
medRxiv preprint doi: https://doi.org/10.1101/2021.10.22.21265316; this version posted October 25, 2021. The copyright holder for this preprint (which was not certified by peer review) is the author/funder, who has granted medRxiv a license to display the preprint in

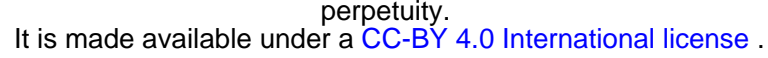

http://www.utstat.toronto.edu/mikevans/jeffrosenthal/book.pdf

63. South African COVID-19 Modelling Consortium. Estimating cases for COVID-19 in South Africa Long-term national projections [Internet]. 2020. Available from: https://www.heroza.org/publications/estimating-cases-forcovid-19-in-south-africa-long-term-national-projections-report-update-6-may-2020/

64. Frost BI, Osena G, Craig J, Hauck S, Kalanxhi E, Gatalo O, et al. COVID-19 in East Africa : National Projections of Exposed, Contagious, Symptomatic \& Severe Cases Overview : COVID-19 in Africa. 2020.

65. Government of South Africa. About alert system [Internet]. COVID-19 / Nov. CORONAVIRUS. 2021 [cited 2021 Oct 7]. p. 1. Available from: https://www.gov.za/covid-19/about/about-alert-system

66. Google. COVID-19 Community Mobility Reports [Internet]. COVID-19 Community Mobil. Reports. 2021 [cited 2021 Oct 7]. p. 1. Available from: https://www.google.com/covid19/mobility/

67. Wallinga J, Teunis P. Different Epidemic Curves for Severe Acute Respiratory Syndrome Reveal Similar Impacts of Control Measures. Am J Epidemiol 2004;160509-516. 2004;160:509-16.

68. NICD. The initial and daily covid-19 effective reproductive number $(\mathrm{R})$ in South Africa [Internet]. Cape Town, South Africa; 2020. Available from: https://www.nicd.ac.za/wp-content/uploads/2020/09/COVID-19-EffectiveReproductive-Number-in-South-Africa_week-38.pdf

69. Gaythorpe K, Imai N, Cuomo-dannenburg G, Baguelin M, Bhatia S, Boonyasiri A, et al. Symptom progression of COVID-19. Imp Coll London COVID-19 Response Team. 2020;1-10.

70. Huang C, Wang Y, Li X, Ren L, Zhao J, Hu Y, et al. Clinical features of patients infected with 2019 novel coronavirus in Wuhan, China. Lancet. 2020;395:497-506.

71. WHO. Clinical management: Living guidance COVID-19. World Heal Organ [Internet]. 2021; Available from: https://www.who.int/publications-detail-redirect/WHO-2019-nCoV-clinical-2021-1

1. WHO. Rolling updates on coronavirus disease (COVID-19) [Internet]. 2020 WHO. 2020 [cited 2020 Jun 22]. Available from: https:/www.who.int/emergencies/diseases/novel-coronavirus-2019/events-as-they-happen

2. JHU CSSE. Novel Coronavirus (COVID-19) Cases Data [Internet]. Johns Hopkins Univ. Cent. Syst. Sci. Eng. (JHU CCSE). 2021 [cited 2021 Oct 3]. p. 1. Available from: https://data.humdata.org/dataset/novel-coronavirus2019-ncov-cases

3. World Bank Group. JUNE 2021 Global Economic Prospects [Internet]. Glob. Econ. Prospect. Washington DC; 2021. Available from: https://openknowledge.worldbank.org/bitstream/handle/10986/35647/9781464816659.pdf

4. UNDP, WHO, BSG. Vaccine inequity undermining global economic recovery. Jt News Release [Internet]. Geneva/New York City; 2021 Jul 22; Available from: https://www.who.int/news/item/22-07-2021-vaccineinequity-undermining-global-economic-recovery

5. Korber B, Fischer WM, Gnanakaran S, Yoon H, Theiler J, Abfalterer W, et al. Tracking Changes in SARSCoV-2 Spike: Evidence that D614G Increases Infectivity of the COVID-19 Virus. Cell [Internet]. 2020;182:812827.e19. Available from: file://C:/Users/ThaboMabuka/Downloads/1-s2.0-S0092867420308205-main.pdf

6. Queiroz K De. The General Lineage Concept of Species and the Defining Properties of the Species Category. In: Howard DJ, Berlocher SH, editors. Endless Forms: Species and Speciation [Internet]. Oxford: Oxford University $\quad$ Press; $\quad$ p. $1998 . \quad 57-75 . \quad$ Available from: https://repository.si.edu/bitstream/handle/10088/4652/VZ_1998deQueirozEndlessForms.pdf

7. Dyson L, Hill EM, Moore S, Curran-sebastian J, Tildesley MJ, Lythgoe KA, et al. Possible future waves of SARS-CoV-2 infection generated by variants of concern with a range of characteristics. Nat Commun [Internet]. Springer US; 2021; Available from: http://dx.doi.org/10.1038/s41467-021-25915-7

8. WHO. Report of the WHO-China Joint Mission on Coronavirus Disease 2019 (COVID-19). WHO-China Jt Mission Coronavirus Dis 2019 [Internet]. 2020;1:40. Available from: https://www.who.int/publicationsdetail/report-of-the-who-china-joint-mission-on-coronavirus-disease-2019-(covid-

19)\%0Ahttps://www.who.int/docs/default-source/coronaviruse/who-china-joint-mission-on-covid-19-finalreport.pdf

9. Wu F, Zhao S, Yu B, Chen YM, Wang W, Song ZG, et al. A new coronavirus associated with human respiratory disease in China. Nature [Internet]. 2020;579:265-9. Available from: https://www.nature.com/articles/s41586- 
medRxiv preprint doi: https://doi.org/10.1101/2021.10.22.21265316; this version posted October 25, 2021. The copyright holder for this preprint (which was not certified by peer review) is the author/funder, who has granted medRxiv a license to display the preprint in

perpetuity.
It is made available under a CC-BY 4.0 International license.

020-2008-3.pdf

10. Raskin S. Genetics of COVID-19. J Pediatr (Rio J) [Internet]. 2021;97:378-86. Available from: https://pubmed.ncbi.nlm.nih.gov/31987001/

11. Shereen MA, Khan S, Kazmi A, Bashir N, Siddique R. COVID-19 infection: Origin, transmission, and characteristics of human coronaviruses. J Adv Res [Internet]. THE AUTHORS; 2020;24:91-8. Available from: https://doi.org/10.1016/j.jare.2020.03.005

12. Cella E, Benedetti F, Fabris S, Borsetti A, Pezzuto A, Ciotti M, et al. SARS-CoV-2 Lineages and Sub-Lineages Circulating Worldwide: A Dynamic Overview. Chemotherapy [Internet]. 2021;66:3-7. Available from: https://www.karger.com/Article/FullText/515340

13. Cascella M, Rajnik M, Cuomo A, Dulebohn SC, Di Napoli R. Features, Evaluation, and Treatment of Coronavirus. StatPearls [Internet]. 2020;19. Available from: http://www.ncbi.nlm.nih.gov/pubmed/32150360

14. Romano M, Ruggiero A, Squeglia F, Maga G, Berisio R. A Structural View of SARS-CoV-2 RNA Replication Machinery: RNA Synthesis, Proofreading and Final Capping. Cells [Internet]. 2020;9. Available from: https://www.ncbi.nlm.nih.gov/pmc/articles/PMC7291026/pdf/cells-09-01267.pdf

15. Finkel Y, Mizrahi O, Nachshon A, Weingarten-Gabbay S, Morgenstern D, Yahalom-Ronen Y, et al. The coding capacity of SARS-CoV-2. Nature [Internet]. Springer US; 2021;589:125-30. Available from: http://dx.doi.org/10.1038/s41586-020-2739-1

16. Izaguirre G. The Proteolytic Regulation of Virus Cell Entry by Furin and Other Proprotein Convertases. Viruses [Internet]. 2019;11:1-19. Available from: https://www.ncbi.nlm.nih.gov/pmc/articles/PMC6784293/pdf/viruses-11-00837.pdf

17. Lu R, Zhao X, Li J, Niu P, Yang B, Wu H, et al. Genomic characterisation and epidemiology of 2019 novel coronavirus: implications for virus origins and receptor binding. Lancet [Internet]. Elsevier Ltd; 2020;395:56574. Available from: http://dx.doi.org/10.1016/S0140-6736(20)30251-8

18. Rambaut A, Holmes EC, O’Toole Á, Hill V, McCrone JT, Ruis C, et al. A dynamic nomenclature proposal for SARS-CoV-2 lineages to assist genomic epidemiology. Nat Microbiol [Internet]. Springer US; 2020;5:14037. Available from: http://dx.doi.org/10.1038/s41564-020-0770-5

19. O’Toole Á, Scher E, Underwood A, Jackson B, Hill V, McCrone JT, et al. Assignment of Epidemiological Lineages in an Emerging Pandemic Using the Pangolin Tool. Virus Evol [Internet]. 2021;7:1-9. Available from: https://watermark.silverchair.com/veab064.pdf?token=AQECAHi208BE49Ooan9kkhW_Ercy7Dm3ZL_9Cf3qf KAc485ysgAAAr8wggK7BgkqhkiG9w0BBwagggKsMIICqAIBADCCAqEGCSqGSIb3DQEHATAeBglghkg BZQMEAS4wEQQMPI0Q5kKsgswQIyYAgEQgIICcvYxjaKS5tJip9doT8tw2asRJSGPjdxeaY9pH3M3g_3rUCN

20. Cevik M, Kuppalli K, Kindrachuk J, Peiris M. Virology, transmission, and pathogenesis of SARS-CoV-2. BMJ. 2020;371:1-6.

21. WHO. Tracking SARS-CoV-2 variants [Internet]. Activities. 2021 [cited 2021 Oct 3]. Available from: https://www/who.int/en/activities/tracking-SARS-CoV-2-variants/

22. CDC. SARS-CoV-2 Variant Classifications and Definitions [Internet]. Var. Surveill. 2021 [cited 2021 Oct 3]. p. 1. Available from: https://www.cdc.gov/coronavirus/2019-ncov/variants/variant-info.html

23. Volz E, Mishra S, Chand M, Barrett JC, Johnson R, Geidelberg L, et al. Assessing transmissibility of SARSCoV-2 lineage B.1.1.7 in England. Nature. 2021;593:266-9.

24. Frampton D, Rampling T, Cross A, Bailey H, Heaney J, Byott M, et al. Genomic characteristics and clinical effect of the emergent SARS-CoV-2 B.1.1.7 lineage in London, UK: a whole-genome sequencing and hospitalbased cohort study. Lancet Infect Dis [Internet]. The Author(s). Published by Elsevier Ltd. This is an Open Access article under the CC BY-NC-ND 4.0 license; 2021;21:1246-56. Available from: http://dx.doi.org/10.1016/S14733099(21)00170-5

25. Mazumder R, Abdullah A, Hossain ME, Rahman MM, Bin Manjur OH, Rahman M, et al. Genome Sequencing Identified a SARS-CoV-2 Lineage B.1.1.7 Strain with a High Number of Mutations from Dhaka, Bangladesh. Microbiol Resour Announc [Internet]. 2021;10:27-9. Available from: https://www.ncbi.nlm.nih.gov/pmc/articles/PMC8201627/pdf/mra.00345-21.pdf 
medRxiv preprint doi: https://doi.org/10.1101/2021.10.22.21265316; this version posted October 25, 2021. The copyright holder for this preprint (which was not certified by peer review) is the author/funder, who has granted medRxiv a license to display the preprint in

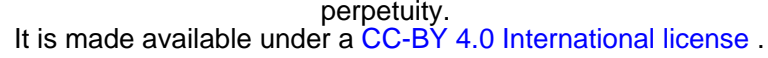

26. Davies NG, Abbott S, Barnard RC, Jarvis CI, Kucharski AJ, Munday JD, et al. Estimated transmissibility and impact of SARS-CoV-2 lineage B.1.1.7 in England. Science (80- ) [Internet]. 2021;372. Available from: https://www.ncbi.nlm.nih.gov/pmc/articles/PMC8128288/pdf/372_abg3055.pdf

27. Faria NR, Mellan TA, Whittaker C, Claro IM, Candido D da S, Mishra S, et al. Genomics and epidemiology of the P.1 SARS-CoV-2 lineage in Manaus, Brazil. Science (80- ) [Internet]. 2021;815-21. Available from: https://www.science.org/doi/epdf/10.1126/science.abh2644

28. Wang P, Casner RG, Nair MS, Wang M, Yu J, Cerutti G, et al. Increased resistance of SARS-CoV-2 variant P.1 to antibody neutralization. Cell Host Microbe 29, [Internet]. 2021;19-21. Available from: https://www.ncbi.nlm.nih.gov/pmc/articles/PMC8053237/pdf/main.pdf

29. Mlcochova P, Kemp S, Dhar MS, Papa G, Meng B, Ferreira IATM, et al. SARS-CoV-2 B.1.617.2 Delta variant replication and immune evasion. Nature [Internet]. 2021; Available from: https://www.nature.com/articles/s41586-021-03944-y_reference.pdf

30. Planas D, Veyer D, Baidaliuk A, Staropoli I, Guivel-Benhassine F, Rajah MM, et al. Reduced sensitivity of SARS-CoV-2 variant Delta to antibody neutralization. Nature [Internet]. Springer US; 2021;596:276-80. Available from: http://dx.doi.org/10.1038/s41586-021-03777-9

31. WHO. COVID-19 Weekly Epidemiological Update 47 [Internet]. COVID-19 Wkly. Epidemiol. Updat. Data. Geneva, Switzerland; 2021. Available from: https://www.who.int/docs/default-source/coronaviruse/situationreports/20210511_weekly_epi_update_39.pdf

32. Cherian S, Potdar V, Jadhav S, Yadav P, Gupta N, Das M, et al. SARS-CoV-2 Spike Mutations, L452R, T478K, E484Q and P681R, in the Second Wave of COVID-19 in Maharashtra, India. Microorganisms [Internet]. 2021;9:1-11. Available from: https://www.nature.com/articles/s41586-021-03944-y_reference.pdf

33. Rosa G La, Brandtner D, Mancini P, Veneri C, Ferraro GB, Bonadonna L, et al. Key SARS-CoV-2 Mutations of Alpha , Gamma , and Eta Variants Detected in Urban Wastewaters in Italy by Long-Read Amplicon Sequencing Based on Nanopore Technology. Water [Internet]. 2021;13. Available from: https://www.mdpi.com/2073$4441 / 13 / 18 / 2503$

34. Duerr R, Dimartino D, Marier C, Zappile P, Wang G, Lighter J, et al. Dominance of Alpha and Iota variants in SARS-CoV-2 vaccine breakthrough infections in New York City. J Clin Invest [Internet]. 2021;131. Available from: https://www.jci.org/articles/view/152702/pdf

35. Janik E, Niemcewicz M, Podogrocki M, Majsterek I, Bijak M. The emerging concern and interest sars-cov-2 variants. Pathogens [Internet]. 2021;10:1-13. Available from: file:///C:/Users/ThaboMabuka/Downloads/pathogens-10-00633-v2.pdf

36. Romero PE, Dávila-Barclay A, Salvatierra G, González L, Cuicapuza D, Solis L, et al. The Emergence of SARS-CoV-2 Variant Lambda (C.37) in South America. medRxiv [Internet]. 2021;2021.06.26.21259487. Available from: https://www.medrxiv.org/content/10.1101/2021.06.26.21259487v1\%0Ahttps://www.medrxiv.org/content/10.11 01/2021.06.26.21259487v1.abstract

37. Kimura I, Kosugi Y, Wu J, Yamasoba D, Butlertanaka EP, Tanaka YL, et al. SARS-CoV-2 Lambda variant exhibits higher infectivity and immune 2 resistance. bioRxiv Prepr [Internet]. 2021;1-31. Available from: https://www.biorxiv.org/content/10.1101/2021.07.28.454085v1.full.pdf

38. NICD. NATIONAL COVID-19 DAILY REPORT [Internet]. Natl. COVID-19 Situat. Summ. 2021 [cited 2021 Oct 3]. p. 1. Available from: nicd.ac.za/diseases-a-z-index/disease-index-covid-19/surveillancereports/national-covid-19-daily-report/

39. NICD. The initial and daily covid-19 effective reproductive number (R) in South Africa. Cape Town; 2020.

40. NICD. FIRST CASE OF COVID-19 CORONAVIRUS REPORTED IN SA [Internet]. 2020 [cited 2020 Jul 6]. Available from: https://www.nicd.ac.za/first-case-of-covid-19-coronavirus-reported-in-sa/\#: :text=This morning\%2C Thursday March 5,Africa on March 1\%2C 2020.

41. Blumberg L, Frean J. COVID-19 SECOND WAVE IN SOUTH AFRICA [Internet]. Cape Town, South Africa; 2020. Available from: https:/www.nicd.ac.za/covid-19-second-wave-in-south-africa/

42. Government of South Africa. President Cyril Ramaphosa: Escalation of measures to combat Coronavirus 
medRxiv preprint doi: https://doi.org/10.1101/2021.10.22.21265316; this version posted October 25, 2021. The copyright holder for this preprint (which was not certified by peer review) is the author/funder, who has granted medRxiv a license to display the preprint in

perpetuity.
It is made available under a CC-BY 4.0 International license.

COVID-19 pandemic [Internet]. 2020 [cited 2020 Jul 7]. Available from: https://www.gov.za/speeches/presidentcyril-ramaphosa-escalation-measures-combat-coronavirus-covid-19-pandemic-23-mar

43. Government of South Africa. Disaster Management Act (57/2002): Regulations made in terms of Section 27(2) by the Minister of Cooperative Governance and Traditional Affairs. Gov Gaz [Internet]. 2020; Available from: https://www.justice.gov.za/legislation/notices/2020/20200325-gg43148-GoN398-COVID19COGTA.pdf.pdf

44. Government of South Africa. Alert Level 5 [Internet]. Pretoria; 2020. Available from: https://www.gov.za/documents/disaster-management-act-regulations-address-prevent-and-combat-spreadcoronavirus-covid-19

45. Government of South Africa. Alert Level 3 [Internet]. Pretoria; 2020. Available from: https://www.gov.za/coronavirus/alert-level-3

46. Government of South Africa. Alert Level 4 [Internet]. Pretoria; 2020. Available from: https://www.gov.za/coronavirus/alert-level-4

47. Government of South Africa. COVID-19 Coronavirus vaccine strategy [Internet]. COVID-19 / Nov. CORONAVIRUS. 2021 [cited 2021 Oct 3]. p. 1. Available from: https://www.gov.za/covid-19/vaccine/strategy

48. Global Change Data Lab. Coronavirus (COVID-19) Vaccinations [Internet]. Our World Data. 2021 [cited 2021 Oct 3]. p. 1. Available from: https://ourworldindata.org/covid-vaccinations

49. Tegally H, Wilkinson E, Lessells RJ, Giandhari J, Pillay S, Msomi N, et al. Sixteen novel lineages of SARSCoV-2 in South Africa. Nat Med [Internet]. Springer US; 2021;27. Available from: http://dx.doi.org/10.1038/s41591-021-01255-3

50. NGS-SA. NGS-SA: NETWORK FOR GENOMIC SURVEILLANCE IN SOUTH AFRICA [Internet]. 2021 [cited 2021 Oct 3]. p. 1. Available from: krisp.org.za/ngs-sa/ngssa_network_for_genomic_surveillance_south_africa/

51. Lessells R, Moosa MY, De Oliveira T. St Augustines Hospital Outbreak Investigation. Final Report 15 May $2020 \quad$ [Internet]. Durban; $2020 . \quad$ Available from: https://www.krisp.org.za/manuscripts/StAugustinesHospitalOutbreakInvestigation_FinalReport_15may2020_co mp.pdf

52. Tegally H, Wilkinson E, Giovanetti M, Iranzadeh A, Fonseca V, Giandhari J, et al. Detection of a SARSCoV-2 variant of concern in South Africa. Nature [Internet]. Springer US; 2021;592:438-43. Available from: http://dx.doi.org/10.1038/s41586-021-03402-9

53. Cele S, Gazy I, Jackson L, Hwa SH, Tegally H, Lustig G, et al. Escape of SARS-CoV-2 501 Y.V2 from neutralization by convalescent plasma. Nature [Internet]. 2021;593:142-6. Available from: https://www.nature.com/articles/s41586-021-03471-w.pdf

54. Elbe S, Buckland-Merrett G, Shu Y, McCauley J. SARS-CoV-2 Sequencing Update 27 September 2021. Track. SARS-COV-2 Var. South Africa; 2021.

55. Scheepers C, Everatt J, Amoako DG, Mnguni A, Ismail A, Mahlangu B, et al. The continuous evolution of SARS-CoV-2 in South Africa: a new lineage with rapid accumulation of mutations of concern and global detection. medRxiv [Internet]. 2021;2021.08.20.21262342. Available from: http://medrxiv.org/content/early/2021/08/24/2021.08.20.21262342.abstract

56. Global Change Data Lab. Coronavirus (COVID-19) Testing [Internet]. Stat. Res. 2021 [cited 2021 Oct 4]. p. 1. Available from: https://ourworldindata.org/coronavirus-testing

57. Jassat W, Cohen C, Kufa T, Goldstein S, Masha M, Cowper B, et al. DATCOV: A SENTINEL SURVEILLANCE PROGRAMME FOR HOSPITALISED INDIVIDUALS WITH COVID-19 IN SOUTH AFRICA, 2020 [Internet]. Johannesburg; 2020. Available from: https://www.nicd.ac.za/diseases-a-z-index/covid19/surveillance-reports/

58. Mabuka T, Ncube N, Ross M, Silaji A, Macharia W, Ndemera T, et al. The Impact of Non-Pharmaceutical Interventions on the First COVID-19 Epidemic Wave in South Africa. medRxiv [Internet]. $2021 ; 2021.06 .29 .21259625$ Available

from: http://medrxiv.org/content/early/2021/07/03/2021.06.29.21259625.abstract 
medRxiv preprint doi: https://doi.org/10.1101/2021.10.22.21265316; this version posted October $25,2021$. The copyright holder for this preprint (which was not certified by peer review) is the author/funder, who has granted medRxiv a license to display the preprint in

It is made available under a CC-BY 4.0 International license .

59. Aron J, Muellbauer J, Thinking NE, Giattino C, Ritchie H, World O. A pandemic primer on excess mortality statistics and their comparability across countries. 2020;1-42.

60. Bradshaw D, Laubscher R, Dorrington R, Groenewald P, Moultrie T. REPORT ON WEEKLY DEATHS IN SOUTH AFRICA 12 - 18 SEPT 2021 [Internet]. 2021. Available from: https://www.samrc.ac.za/reports/reportweekly-deaths-south-africa

61. Hethcote HW. Three Basic Epidemiological Models. 1989;119-44.

62. Evans MJ, Rosenthal JS. Probability and Statistics The Science of Uncertainty [Internet]. Second Edi. Meas. Uncertain. Probab. Toronto: University of Toronto; 2009. Available from: http://www.utstat.toronto.edu/mikevans/jeffrosenthal/book.pdf

63. South African COVID-19 Modelling Consortium. Estimating cases for COVID-19 in South Africa Long-term national projections [Internet]. 2020. Available from: https://www.heroza.org/publications/estimating-cases-forcovid-19-in-south-africa-long-term-national-projections-report-update-6-may-2020/

64. Frost BI, Osena G, Craig J, Hauck S, Kalanxhi E, Gatalo O, et al. COVID-19 in East Africa : National Projections of Exposed, Contagious, Symptomatic \& Severe Cases Overview : COVID-19 in Africa. 2020.

65. Government of South Africa. About alert system [Internet]. COVID-19 / Nov. CORONAVIRUS. 2021 [cited 2021 Oct 7]. p. 1. Available from: https://www.gov.za/covid-19/about/about-alert-system

66. Google. COVID-19 Community Mobility Reports [Internet]. COVID-19 Community Mobil. Reports. 2021 [cited 2021 Oct 7]. p. 1. Available from: https://www.google.com/covid19/mobility/

67. Wallinga J, Teunis P. Different Epidemic Curves for Severe Acute Respiratory Syndrome Reveal Similar Impacts of Control Measures. Am J Epidemiol 2004;160509-516. 2004;160:509-16.

68. NICD. The initial and daily covid-19 effective reproductive number (R) in South Africa [Internet]. Cape Town, South Africa; 2020. Available from: https://www.nicd.ac.za/wp-content/uploads/2020/09/COVID-19-EffectiveReproductive-Number-in-South-Africa_week-38.pdf

69. Gaythorpe K, Imai N, Cuomo-dannenburg G, Baguelin M, Bhatia S, Boonyasiri A, et al. Symptom progression of COVID-19. Imp Coll London COVID-19 Response Team. 2020;1-10.

70. Huang C, Wang Y, Li X, Ren L, Zhao J, Hu Y, et al. Clinical features of patients infected with 2019 novel coronavirus in Wuhan, China. Lancet. 2020;395:497-506.

71. WHO. Clinical management: Living guidance COVID-19. World Heal Organ [Internet]. 2021; Available from: https://www.who.int/publications-detail-redirect/WHO-2019-nCoV-clinical-2021-1 